\title{
Monitoring the Sustainable Intensification of Arable Agriculture: the Potential Role of Earth Observation
}

Merryn L. Hunt*a,b, George Alan Blackburn ${ }^{b}$, Clare S. Rowland ${ }^{a}$

${ }^{a}$ Centre for Ecology and Hydrology, Lancaster Environment Centre, Library Avenue, Bailrigg, Lancaster, United Kingdom, LA1 4AP

${ }^{\mathrm{b}}$ Lancaster Environment Centre, Library Avenue, Lancaster University, Lancaster, United Kingdom, LA1 4YQ

*Corresponding author email address: $\underline{\text { m.hunt3@lancaster.ac.uk (M. L. Hunt) }}$

\begin{abstract}
Sustainable intensification (SI) has been proposed as a possible solution to the conflicting problems of meeting projected increase in food demand and preserving environmental quality. SI would provide necessary production increases while simultaneously reducing or eliminating environmental degradation, without taking land from competing demands. An important component of achieving these aims is the development of suitable methods for assessing the temporal variability of both the intensification and sustainability of agriculture. Current assessments rely on traditional data collection methods that produce data of limited spatial and temporal resolution. Earth Observation (EO) provides a readily accessible, long-term dataset with global coverage at various spatial and temporal resolutions. In this paper we demonstrate how EO could significantly contribute to SI assessments, providing opportunities to quantify agricultural intensity and environmental sustainability. We review an extensive body of research on EO-based methods to assess multiple indicators of both agricultural intensity and environmental sustainability. To date these techniques have not been combined to assess SI; here we identify the opportunities and initial steps required to achieve this. In this context, we propose a development of a set of essential sustainable intensification variables (ESIVs) that could be derived from EO data.
\end{abstract}

Keywords: Sustainable intensification assessment; Earth Observation; agricultural intensity indicators; environmental sustainability indicators; crop yield; vegetation health; soil quality; water quality; biodiversity; ecosystem health

\section{Introduction}

With a projected population increase of 2.3 billion by 2050, increases in income and shifting food consumption patterns, global food production must increase by an estimated $70 \%$ to meet growing demand (Campbell et al., 2014; Caviglia and Andrade, 2010; Dillon et al., 2016; FAO, 2009; Garnett et al., 2013; Lampkin et al., 2015; Schut et al., 2016; Tilman et al., 2011, 2002). Both agricultural expansion (clearing additional land for crop production) and intensification (increasing productivity of existing agricultural land) could provide necessary crop production increases (Godfray and Garnett, 2014; Tilman et al., 2011). Current competition for land restricts the potential for conversion of new land to agriculture, thus limiting the viability of expansion in many cases (Godfray et al., 2010; Pretty et al., 2011). In addition, expansion is thought to have a greater detrimental impact on the environment than intensification, with potential for significant greenhouse gas release through land conversion and major biodiversity losses affecting essential ecosystem service provision (Garnett et al., 2013; Godfray and Garnett, 2014). Consequently, future demands must be met through production increases on current agricultural land alongside shifts in diet and the reduction in food waste (including transport and consumption). Previous agricultural intensification (Al) has been achieved through changes in management practices including increased agrochemical 
inputs, cropping intensity and irrigation, and adoption of monoculture practices (Benton et al., 2003; Crowder and Jabbour, 2014; Meeus, 1993; Stoate et al., 2001). However, it is now widely recognised that such intensification measures detrimentally impact the environment, through over exploitation of natural resources for inputs and emission of pollution and waste (Pretty et al., 2011). This raises concerns over the long-term ability to maintain intensive agricultural practices, with intensification-induced environmental degradation having negative feedbacks on sustained crop productivity (Bommarco et al., 2013; Foley et al., 2005; Matson et al., 1997). It is clear therefore that a sustainable method of agricultural intensification is required.

One possible solution is sustainable intensification (SI), which involves increasing production efficiency to achieve higher agricultural outputs with the same or fewer inputs, while simultaneously significantly reducing or eliminating environmental degradation (Dillon et al., 2016). However, no definitive mechanisms of SI exist, with the success of different methods dependent on situation-specific conditions. As such, to ensure any attempts at $\mathrm{SI}$ are successful suitable methods are required to assess the sustainability of intensification efficiently over diverse landscapes and spatial scales on a long-term basis.

The purpose of this review is to outline the current state of $\mathrm{SI}$ assessments and explore the potential contributions EO could make. While it is true that various studies have used EO to assess either agricultural intensity or various indicators of environmental sustainability, to date no one has attempted to combine established EO-based methods to provide an actual assessment of sustainable intensification. Hence, this review explores the basis for the development of an operational SI monitoring system that uses EO data. This review is structured as follows. Section 2 provides an overview of the key concepts of agricultural intensification (AI) and $\mathrm{SI}$, as well as briefly introducing $\mathrm{SI}$ assessment. Section 3 and Section 4 present a more detailed outline of the current approaches used to assess agricultural intensity and agricultural environmental sustainability, respectively, highlighting ways in which EO data is presently used and further contributions it could make. The review concludes with a discussion of the opportunities of EO to contribute towards an operational SI monitoring system applicable for a range of spatial and temporal scales. This review focuses on the intensification arable agriculture; as such methods for monitoring pastoral agriculture are not explicitly discussed.

\section{Key concepts/definitions}

\subsection{Agricultural Intensification (AI)}

Agricultural intensification (AI) is the "increase in agricultural production per unit of inputs", where inputs may include labour, land, time, seed, fertiliser, feed or cash (FAO, 2004). Intensification can refer to maintenance of current production with decreased inputs, and/or increased production through higher input productivity (FAO, 2004). Methods of intensification include: increased agrochemical inputs; increased cropping intensity (e.g. double or triple cropping); increased crop density; removal of linear and point features such as hedgerows and ponds (landscape simplification and field enlargement); decreased crop diversity (monoculture adoption); and increased irrigation (e.g. Crowder and Jabbour, 2014; Donald et al., 2001; Newton, 2004; Stoate et al., 2001). Detrimental environmental impacts of Al are wide-ranging, covering a range of spatial (local to global) and temporal (short-term to long-term or permanent) scales. These factors are driving the growing interest in alternative, more sustainable methods for meeting growing food demand. Figure S1 in the supplementary material highlights some of the key environmental impacts of various mechanisms of agricultural intensification. The potential for environmental degradation resulting from Al activities is intensified by the complexity of the agricultural environment, with numerous interactions, connections and feedbacks within the system, and multiple causal relationships. Such degradation could have significant impacts both within the immediate vicinity of intensification and over wider spatial scales. The wide range of potential impacts and system complexity poses a challenge when trying to devise a monitoring system that can accurately measure all required elements. 


\subsection{Sustainable Intensification (SI)}

Sustainable Intensification (SI) has been proposed as an alternative to conventional intensification providing necessary yield increases, whilst ensuring environmental degradation is kept at a sustainable level (Tilman et al., 2011). The concept originated in the 1990s (Buckwell et al., 2014), with much debate since over the exact definition of the term "sustainable intensification". A common definition describes $\mathrm{Sl}$ as a form of production wherein greater yields are produced with the same or fewer inputs, while adverse environmental impacts are simultaneously reduced or eliminated and contribution to natural capital and ecosystem service flow is increased (Barnes and Thomson, 2014; Dillon et al., 2016; Garnett and Godfray, 2012; Godfray et al., 2010; Pretty, 2008; Pretty et al., 2011). SI as a concept prescribes no particular development paths or methods; the aim is simply to create resource efficient agriculture with significantly better environmental performance than conventional intensification (Buckwell et al., 2014). Instead, a framework is provided facilitating exploration of the optimum mix of approaches based on existing situation-specific biophysical, social, cultural and economic contexts (Buckwell et al., 2014; Garnett et al., 2013; Garnett and Godfray, 2012; Pretty and Bharucha, 2014). The suitability of different methods varies depending on conditions, as well as current agricultural productivity and environmental performance of the system (Buckwell et al., 2014; Garnett and Godfray, 2012).

Possible interventions to achieve SI include: Integrated Pest Management (IPM), use of on- and off-farm biodiversity to manipulate pest ecologies; Agroforestry Systems, for example intercropping; Precision Agriculture; and Conservation Agriculture (Pretty and Bharucha, 2014).

\subsection{Assessing Sustainable Intensification}

As there is no definitive mechanism for $\mathrm{SI}$, realising the goal of resource efficient agriculture requires suitable methods to assess the sustainability of intensification efficiently over diverse landscapes and spatial scales on a longterm basis. Current assessment attempts rely largely on farm surveys (questionnaires and interviews), field data, national government statistics and other traditional data sources. Data collection is often costly and time consuming, limiting the spatial and temporal scale and extent, with consequent impacts on the representativeness of both the data and the assessments. As such, the current reliance on interpolation of point data and average statistics severely restricts timely provision of accurate sustainability assessments for all agricultural areas. Deficiencies such as these highlight the need for a new, more efficient assessment technique.

Generally, studies focus on either agricultural sustainability, with no explicit attempt to quantify intensification (e.g. Dillon et al., 2010; Rasul and Thapa, 2004), or on agricultural intensity at a specific point in time, with no assessment of sustainability (e.g. Herzog et al., 2006; Niedertscheider et al., 2016). Studies that assess the sustainability of intensification are largely conducted on farms where management practices are known to have shifted towards more intensive measures; hence, no attempt is made to quantify the degree or rate of intensification. The few studies that do include a measure of intensity (e.g. crop yield) commonly ignore change over time and use a single point in time. Intensification is a process rather than a fixed end state; looking at intensity at one specific time is therefore not sufficient (Elliott et al., 2013; Firbank et al., 2013). To get a full picture of the sustainability of any intensification in agricultural production, the change that has occurred over time must be investigated and trends identified to determine the actual environmental impacts. The potential of a quantified SI assessment approach at the individual farm level, using data held by farmers from two different years, was explored by Firbank et al. (2013). Results demonstrated the ability to assess sustainability of farms adopting different management strategies, but the data source restricted the completeness of the assessment, limiting measurable indicators and identifiable spatial and temporal variation. The limited temporal resolution of the data restricted full exploration of the intensification and subsequent effects on yield and environmental sustainability. The study constitutes an important step in the development of an operational SI assessment method, but more comprehensive data is required. 
Ideally, field measurements would be taken at all locations to provide data on which SI could be assessed. However, as this is not feasible, data sources with greater spatial and temporal coverage and lower acquisition costs must be sought that can be used in conjunction with field measurements. Incorporation of satellite data into sustainability assessments could allow greater flexibility, over various spatial and temporal scales, providing more accurate and representative results at lower costs. Recent decades have seen considerable increases in Earth Observation (EO) data use, with applications in diverse research areas. A number of international monitoring systems have been developed incorporating satellite data for crop condition monitoring and yield forecasting over regional, national and global scales. Such systems include the Group on Earth Observations Global Agricultural Monitoring system (GEOGLAM) (GEO, n.d.), the USDA Foreign Agricultural Service (FAS) Global Agricultural Monitoring (GLAM) System (USDA FAS, n.d.), the Chinese Academy of Sciences Crop Watch Program (Bingfang, 2006), and the Monitoring Agriculture by Remote Sensing (MARS) project developed by the Joint Research Centre of the European Commission (European Commission, 2016). The operational status of these systems demonstrates the value of EO for agricultural monitoring. Outputs from these systems could be used to monitor intensification, but currently this is not done explicitly. The potential contribution of these EO-based systems to SI assessment has so far not been fully explored or realised, with little or no evidence of the use of satellite-derived data within agricultural sustainability assessments.

To date EO researchers have not explicitly attempted to quantify SI and so intensity and environmental sustainability have not been assessed for the same sites from EO. This review treats aspects of sustainability and intensification separately to provide a comprehensive overview of current research and the potential contribution of Earth Observation. The next two sections provide a more detailed overview of the methods used to assess both agricultural intensity and sustainability, highlighting the ways in which satellite data is used at present and the opportunities moving forwards.

\section{$\underline{\text { 3. Assessing the Intensity of Arable Production }}$}

\subsection{Current Approaches}

The types of indicators used to assess agricultural intensity differ between studies. Some focus on indicators which reflect the increase in land productivity caused by human intervention (Dietrich et al., 2012) such as yield per ha (e.g. Singh et al., 2002). Others focus on indicators which measure the change in inputs or other factors of management (Shriar, 2000) including total nitrogen (fertiliser) input (e.g. Temme and Verburg, 2011), number of pesticide applications (e.g. Herzog et al., 2006), and inputs costs per ha (e.g. Teillard et al., 2012). As such, the range of indicators used to assess agricultural intensity can be split into two general groups: agricultural input indicators (e.g. input cost per ha, crop acreage) and agricultural output indicators (e.g. production per area and time). Examples of indicators used in EO-based studies can be found in table 1. Some direct indicators of agricultural intensity, such as fertiliser and pesticide input cannot be measured using EO, but may be detectable indirectly from, for example, changes in yield. Typically either a single indicator is adopted to assess intensity (e.g. Biradar and Xiao, 2011; Mingwei et al., 2008), or multiple indicators are aggregated to produce an intensity index (e.g. Kerr and Cihlar, 2003; Shriar, 2000). Aggregated indicators simplify complex situations into a single element, but this is done at the expense of interpretability and transparency. Whether a single indicator or an index is appropriate will vary depending on the purpose of the study (Herzog et al., 2006). 


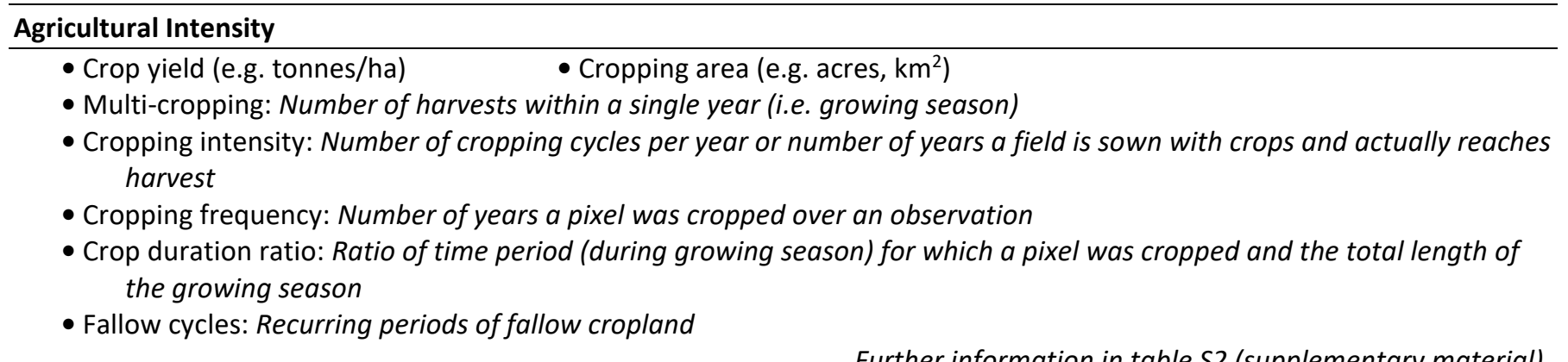

Table 1: Key EO-derived indicators for assessing agricultural intensity. Examples of methods to derive these EO-based indicators can be found in tables $\mathrm{S} 2$ in the supplementary material.

Data sources for agricultural intensity assessments include interviews, government statistics, field and farm surveys, aerial photographs and satellite data (see table S1 in the supplementary material for further examples of data sources and indicators used by various authors to investigate agricultural intensity). EO techniques are fairly common within this area, with a range of satellites appearing within the literature including MODIS, AVHRR, Landsat and Sentinel. EO-based methods used to investigate agricultural intensity vary depending on the indicator of interest; some examples of specific methods can be found in table $S 2$ in the supplementary material.

EO has a range of advantages over other data sources for intensity assessments. The use of EO allows better cross-country comparisons to be made; country boundary restrictions do not apply in the same way as to government statistics data, thus improving data consistency (Herzog et al., 2006). Additionally, low-cost methods using relatively simple technology can be developed, allowing application of EO-based methods in areas where costs of traditional data collection methods prohibit reliable intensity assessments (Ferencz et al., 2004). Furthermore, EObased cropping indicators perform well for broad-scale agricultural monitoring, suggesting they could complement (potentially) more accurate sample-based ground-data, by providing wall-to-wall observations of agricultural management (Estel et al., 2016). Lack of spatially distributed information on key environmental and agronomic variables tends to limit application of crop simulation models for regional scale yield estimation (Moriondo et al., 2007). EO data can alleviate this problem, by providing estimates of relevant variables over a range of spatial and temporal scales.

\subsection{Potential for Expanding the Use of EO to Assess Agricultural Intensity}

As previously noted, the use of EO within agricultural intensity studies is already fairly common, but it is still not typically routine and operational. In addition, with continued advancements in sensor technology, the launch of new satellites and the development of new methods, the full potential of EO has yet to be realised. Moving forward research should continue to focus on the creation of high resolution, global products which can be provided regularly (annually), consistently and in a timely manner (e.g. Claverie et al., 2018; Egorov et al., 2019; Roy et al., 2010). In the past, the production of high resolution operational EO-derived products was hindered by a lack of suitable cloud-free imagery and the time and computing power required to process the vast number of images needed to provide global coverage. However now, with an increase in the number of moderate and high resolution satellites, improvements in gap-filling and sensor integration techniques, and the advent cloud computing systems that can facilitate more rapid processing, the potential for producing high resolution EO products for assessing agricultural intensity on a global scale has never been greater. Work is already underway to produce a variety of large-scale high-resolution $(30 \mathrm{~m})$ products, for example, cropland extent maps on a country- (e.g. Teluguntla et al., 2018) and continental-scale (e.g. Xiong et al., 2017). International programmes such as GEOGLAM and commercial organisations such as OneSoil (OneSoil, 2018) are also working to map various agricultural parameters, including crop type and crop condition/development, on a global scale. The timely production of high resolution, global products, which provide an accurate representation of the diverse agrosystems around the world, is likely to require 
either the development of generic, transferable models or an increase in the collection and provision of in situ data. In reality, the solution will probably involve some combination of the two.

The accessibility of appropriate field data for calibration and validation is a major constraint on the development of an operational EO-based system for assessing intensification. A step-change in monitoring capability could be provided by having EO as part of an integrated system that makes in situ data routinely available. Similarly, the creation and adoption of better data fusion methods may help with interpretation of the EO system, limiting the impact of confounding factors, and improving assessment potential. However, despite the various challenges which exist at present, EO data provides an important, practical and viable approach for regional and global monitoring of land surface dynamics, including variations in agricultural intensity (Yan et al., 2014). The value of EO for agricultural intensity assessments lies, in part, in the spatially explicit nature of the data, consistency across political borders and the systematic acquisition setup (Kuemmerle et al., 2013).

\section{Assessing the Environmental Sustainability of Arable Systems}

\subsection{Current Approaches}

Sustainability has three dimensions: economic, social and environmental sustainability (Allahyari et al., 2016). EO has the potential to contribute valuable information on the environmental dimension however, to provide a comprehensive assessment of sustainability, EO must be used alongside datasets covering economic and social variables. Accepted socio-economic indicators are regularly (e.g. yearly) monitored by governments and international organisations (e.g. United Nations, World Health Organisation) on a regional, national and global scale. This provides a readily available, long-term dataset for economic and social sustainability, something that is not currently available for environmental sustainability. Consequently, in this review the focus is on the environmental dimension of sustainability.

Assessing environmental sustainability is a complex process fraught with challenges and pitfalls. Selection of appropriate indicators, weighting and aggregation methods for specific situations and requirements are essential to the successful assessment of sustainability. A number of frameworks have been developed to aid in the selection and aggregation of appropriate indicators, to provide a single score by which sustainability of agricultural systems can be assessed. These frameworks differ in their definition of sustainability, indicator selection approach, and aggregation and validation methods. Frameworks include

- SAFA: Sustainability Assessment of Food and Agriculture Systems (FAO, 2014, 2013)

- IDEA: Indicateur de Durabilité des Exploitations Agricoles (Zahm et al., 2008)

- ISAP: Indicator of Sustainable Agricultural Practice (ISAP) (Rigby et al., 2001)

- RISE: Response-Inducing Sustainability Evaluation (RISE) (Häni et al., 2003, 2006)

- SAFE: Sustainability Assessment of Farming and the Environment (Van Cauwenbergh et al., 2007)

- SSP: Sustainability Solution Space for Decision Making (Wiek and Binder, 2005)

- Sustainable Intensification Assessment Framework (Musumba et al., 2017; Snapp et al., 2018)

Issues surrounding the use of indicators and frameworks are explored in other publications (e.g. Binder et al., 2010; Binder and Wiek, 2006; Gómez-Limón and Sanchez-Fernandez, 2010; Roy and Chan, 2012; Singh et al., 2009; Smith et al., 2017; Stein et al., 2001) so no further discussion will be presented here.

Current agricultural sustainability studies generally rely on a mixture of primary and secondary data including: questionnaires, field data collection (e.g. soil sampling, spatial information) and government statistics (e.g. 
Gómez-Limón and Sanchez-Fernandez, 2010; Rasul and Thapa, 2004; Rodrigues et al., 2010; Zhen et al., 2005). There are however a number of challenges specifically arising as a consequence of current data sources and collection methods which limit the ability to accurately and efficiently assess environmental sustainability:

(1) No baseline data - Sustainability studies frequently lack baseline data, using data from a single point in time. This prevents analysis of temporal variability. Multi-temporal datasets would enable more comprehensive and therefore more reliable assessments.

(2) Uncertainty from sample data interpolation - Reliance on sample data and interpolation or averaging techniques limit the potential to accurately assess spatial variability. Ideally all points would be sampled, providing (near-) continuous coverage, however, the cost and time required to complete such a task, clearly makes this impossible using traditional data collection techniques. Current assessments assume the sample data are representative of the wider study area, which may introduce error.

(3) Subjective data - Frequent use of questionnaires, farm surveys and interviews arguably affects the objectivity of many studies. Apart from obvious issues over the truth of answers, subjectivity of qualitative collection methods limits the extent to which data can be integrated and compared. Use of objective, quantified data would likely improve assessment capabilities.

(4) Limited data - Data availability, resolution and coverage (both spatial and temporal) are often limited by costly and time-consuming collection methods. Bias may also exist, with data less readily available in more inaccessible and poorer areas. Sustainability assessments are important in all areas if food demands are to be met and environmental quality maintained or improved; lack of necessary data due to traditional data collection methods hinders this.

EO has the potential to reduce some of these issues when assessing environmental sustainability.

\subsection{Potential Applications of EO-based Methods for Assessing Environmental Sustainability}

The potential applications for EO-based methods are described by splitting environmental sustainability into five key areas: (1) vegetation health; (2) soil quality; (3) water quality and availability; (4) biodiversity; and (5) ecosystem health (table 2). Environmental sustainability does encompass other aspects however the ability to assess elements such as air quality using EO, at scales relevant to agricultural systems, is restricted. This review therefore focuses on the areas considered to have most potential for assessment via EO-derived indicators for agriculturebased studies. Research efforts have not been evenly split between the areas covered in this section. However, to maintain a consistent structure and attempt to provide a balanced overview, each has approximately equal coverage in this section. 
Environmental Sustainability

Vegetation health

- Crop condition

- Biophysical traits inc. biomass, fraction of absorbed photosynthetically active radiation (fAPAR), photosynthetic activity

- Structural traits inc. crop/canopy height, leaf area index (LAI), biomass, canopy morphology

- Biochemical traits inc. chlorophyll (Ch), water content, nitrogen $(N)$ and phosphorous $(P)$

Further information in table S3 (supplementary material)

Soil Quality

- Soil organic carbon (SOC) • Soil organic matter (SOM) • Soil moisture content • Soil salinity

- Crop residue/conservation tillage density - Nitrogen status/availability

Further information in table 54 (supplementary material)

Soil erosion/protection

- Vegetation cover • Erosion feature detection • Erosion modelling e.g. USLE

Further information in table S4 (supplementary material)

\section{Water Quality}

- Water Quality Indices derived from different spectral band combinations

- Physical water quality parameters inc. total suspended solids (TSS), turbidity, suspended sediment concentration (SSC), chlorophyll concentration, temperature and water clarity

- Chemical water quality parameters inc. concentration of total nitrogen, $\mathrm{NO}_{3}-\mathrm{N}$ (nitrate as nitrogen) and total phosphorous

- Water quality proxy e.g. health of vegetation alongside water bodies

Further information in table S5 (supplementary material)

Water Availability

- Water body area and configuration

- Water level and volume

- Water use efficiency and crop water stress

Further information in table S5 (supplementary material)

\section{Biodiversity}

- Direct mapping of individuals and associations

- Plant (and animal) species diversity

- Habitat suitability based on known habitat requirements of specific species

- Species Richness

- Landscape structure inc. composition, isolation and complexity - Invasive Species

Further information in table S6 (supplementary material)

\section{Ecosystem Health}

- Vigour

- Net Primary Productivity (NPP) \& Gross Primary Productivity (GPP)

- Fractional cover of green vegetation, non-photosynthetic vegetation (NPV) and bare soil

- Biochemical properties inc. nitrogen, phosphorous and chlorophyll

- Organisation

- Species richness and biodiversity

- Vegetation structural traits
- Resilience

- Ecosystem Services as a Proxy for Ecosystem Health

Further information in table S7 (supplementary material)

Table 2: Potential EO-based indicators which could be used to assess environmental sustainability. Examples of EO-based methods to derive these indicators can be found in tables S3 to S7 in the supplementary material.

\subsubsection{Vegetation Health}

Environmental quality depends in part on the presence of healthy, diverse and abundant vegetation to provide ecosystem services including soil protection, carbon sequestration and flood prevention (Crossman et al., 2013; Hein, 2014). Vegetation health, in turn, relies on a healthy environment to provide essential resources, including stable soil substrate and nutrients. This interdependence suggests that agricultural and non-agricultural vegetation health can be used as an indicator of environmental quality within the agricultural system. Various aspects of vegetation health have been assessed using EO over a range of spatial (e.g. field-/plot-scale to tens/hundreds $\mathrm{km}^{2}$ and global scale) and temporal scales (e.g. single date assessments to decadal variation), in a 
diverse range of environments (e.g. grasslands, shrublands, forests, rainforests, mountainous regions), including agricultural systems (e.g. corn farms, irrigated maize). Many of these studies were conducted using freely available satellite data including Landsat, MODIS and AVHRR, suggesting established methods exist, which can be readily applied to a range of environments. Examples of EO-based methods used to assess vegetation health can be found in table S3 in the supplementary material.

Empirical models are commonly used to assess a variety of vegetation health-related properties. The frequency and timing of image acquisition affects the strength of relationships between specific vegetation indices (VIs) (e.g. NDVI) and related variables (e.g. net primary productivity) (Tebbs et al., 2017). In some situations it may therefore be preferable to use coarser spatial resolution satellites which provide daily coverage (e.g. MODIS), instead of finer spatial resolution satellites with less frequent data acquisition (e.g. Landsat) (Jackson et al., 2004). The successful application of Radiative Transfer Models (RTMs) demonstrates the potential to develop (simple) algorithms to predict various plant traits from satellite data, spanning a range of vegetation types (Myneni et al., 1997; Trombetti et al., 2008).

\subsubsection{Soil Quality}

Deterioration of soil quality through intensive use of agricultural land has far-reaching impacts affecting plant productivity, water and air quality (Doran and Zeiss, 2000). Soil quality is therefore an important indicator of sustainability and has been studied over a range of scales, from $10 \mathrm{~s}$ to $1000 \mathrm{sm}^{2}$, and across diverse landscapes including cultivated, semi-natural and natural vegetation areas using EO data. Previous studies clearly demonstrate the great potential for soil quality assessment in agricultural areas. However, disparity between achievable spatial resolutions with current freely available satellite data (e.g. Landsat) and typical agricultural field sizes limits the ability to conduct field-scale assessments in some parts of the world. Examples of methods used to assess soil quality and erosion/protection using EO data can be found in table S4 in the supplementary material.

Soil reflectance is a function of the soil's physical properties such as soil moisture and soil organic carbon, but also tillage practices, crop residue and row orientation. Multispectral imagery is therefore best suited for application to farms with uniformly tilled fields and constant soil moisture conditions at the time of image acquisition; such conditions increase the dominance of the property of interest in the spectral response (Barnes and Baker, 2000). Microwave sensors allow direct soil moisture estimates by exploiting the relationship between moisture content and the dielectric constant of the soil (Wagner et al., 2007). Polarisation and study site conditions influence detection of soil parameter variation. For example, at low moisture conditions, vertical polarisation offers higher sensitivity to salinity; at high moisture levels horizontal polarisation exhibits slightly higher sensitivity (Lasne et al., 2008; Shoshany et al., 2013).

\subsubsection{Water Quality and Availability}

Al can negatively affect both quality and availability of water resources, so sustainability assessments should consider both. EO-based water quality and availability assessments have focused predominantly on large water bodies such as lakes, reservoirs and coastal environments, for non-agriculture-related investigations. Although the methodology may theoretically be transferable to agricultural environments, the applicability of EO methods to sustainability assessments depends partly on the scale of the study. Water bodies of interest for field- or farm-based assessments are likely to be much smaller than can easily be detected by current satellites due to limiting spatial resolutions; as sensors continue to develop the potential to adopt such methods will increase. At present, EO-based water-related assessments are likely to be most suitable for catchment- or regional-scale investigations, where the impact of multiple farms on larger water bodies is considered using coarser resolution data. Some of the common EO-based methods used to assess water quality and availability are outlined in table $\mathrm{S} 5$ in the supplementary material. 
Water quality assessments commonly employ empirical models to estimate physical and chemical water quality parameters. Transference of empirical methods to areas and circumstances for which they were not formulated adds uncertainty and may not be appropriate. For example, current generation satellite sensors have limited ability to map chlorophyll content in mesotrophic and oligotrophic water, despite successful application for eutrophic and hyper-eutrophic water (Gons et al., 2008). However, understanding the limitations of the empirical relationships means they can be applied appropriately. For example a set of robust relationships established between suspended sediment concentration and MODIS spectral reflectance data can be applied, but only for rivers larger than 500m (Martinez et al., 2008).

The operational feasibility of applying a single water body detection algorithm over diverse environmental and climatic conditions has been demonstrated, producing results with a high-degree of accuracy (Mueller et al., 2016). The spatial resolution of satellite altimetry is about 1.7 to $3 \mathrm{~km}$ (for calm waters), so water level assessments have typically targeted large lakes or rivers, however, satellite altimetry-based techniques have been successfully applied to medium-sized water bodies (200-800m wide), with some potential for application to small-sized water bodies (40-200m wide) (Sulistioadi et al., 2015).

\subsubsection{Biodiversity}

Al has been linked with biodiversity losses on local, regional and global scales. Biodiversity helps maintain ecosystem health and provision of ecosystem services, so its loss can have serious implications for human well-being (Pettorelli et al., 2014; Turner et al., 2015). Preservation or ideally enhancement of biodiversity is essential for sustainable agriculture, hence the spatial and temporal variability of biodiversity is an important indicator of sustainability. The use of EO to monitor biodiversity has been reviewed by a number of authors, who have outlined key methods, challenges and opportunities (e.g. Gillespie et al., 2008; Kerr and Ostrovsky, 2003; Kuenzer et al., 2014; Mairota et al., 2015; Nagendra, 2001; Rocchini et al., 2010; Turner et al., 2003; Wang et al., 2010). Consequently, in this review we provide only a brief overview covering examples of indicators and related methods (table 2). Examples of some EO-based methods used to assess biodiversity can be found in table $\mathrm{S} 6$ in the supplementary material.

Biodiversity can be assessed using both direct and indirect techniques. Individual plants or associations of single species may be directly mapped using (very) high spatial resolution satellite images. Where direct mapping of biodiversity indicators is not feasible, indirect approaches that rely on environmental parameters as proxies may be adopted (Turner et al., 2003). Both species abundance and richness are considered to be fundamentally affected by landscape heterogeneity; more heterogeneous landscapes can host more diverse species than homogeneous landscapes due to greater niche availability (Feng et al., 2010; Honnay et al., 2003). EO-derived measures of landscape structure such as composition, complexity and isolation can therefore be used to predict species distribution and diversity. Habitat fragmentation and removal of connectivity elements (e.g. hedgerows) negatively affect species richness and distribution; this relationships allows species richness predictions based on relatively simple landscape metrics (Griffiths and Lee, 2000; Honnay et al., 2003). Lack of consideration of environmental factors such as temperature and disturbance, which affect biodiversity, may reduce accuracy of LC- and landscape metric-based predictions (Griffiths and Lee, 2000; Li et al., 2014).

Satellite-derived habitat maps can be used in conjunction with known habitat requirements to model potential distribution and abundance of individual species (e.g. Nagendra, 2001; Weiers et al., 2004); habitat suitability parameters such as the existence of suitable water bodies can be derived to assist this modelling (e.g. Weiers et al., 2004). Habitat-based species distribution modelling requires LC data of sufficient spatial and thematic resolution to ensure all habitats that the target species could potentially occupy are identified; in situ or ancillary data is almost certainly necessary to meet requirements for predicting actual distributions of many species (Kerr and Ostrovsky, 2003). Where species do not occupy all suitable habitats, only potential rather than actual distribution 
can be predicted (Davis et al., 2007; Kerr and Ostrovsky, 2003). A limitation of using habitat maps to predict species distribution and diversity is the fact that this provides no insight into within-habitat variation (Nagendra, 2001).

\subsubsection{Ecosystem Health}

Ecosystem (ES) health affects the ability of ecosystems to provide essential services. A sustainable ecosystem is one which has the ability to maintain its function (or vigour) and structure (or organisation) over time and is resilient even with the application of external stress (Costanza and Mageau, 1999). The potential of EO has been acknowledged and reviewed previously by other authors (e.g. Andrew et al., 2014; Feng et al., 2010; Li et al., 2014). Assessments generally focus on three aspects of ES health: vigour, a measure of a system's activity, metabolism and primary productivity; organisation, the number and diversity of interactions between a system's components; and resilience, a system's ability to maintain its pattern and structure in the presence of stress (Costanza and Mageau, 1999; Li et al., 2014; Li and Guo, 2012). Common indicators of ES health are GPP or NPP (for vigour), species richness and diversity (for organisation) and the ratio of an ES health indicator pre- and post-disturbance (for resilience) (Costanza and Mageau, 1999; Li et al., 2014; Li and Guo, 2012) (table 2). Examples of some possible EO-based methods for assessment of ecosystem health can be found in table $\mathrm{S} 7$ in the supplementary material.

Ecosystem health can also be assessed using the supply of ecosystem services (ESS) as a proxy. ESS represent the goods and services supplied by organisms and their activities, controlled by the abiotic characteristics of the system and the anthropogenic impacts it experiences (Andrew et al., 2014). Agricultural systems are both a source and beneficiary of ESS (Balbi et al., 2015; Power, 2010). RS-based ESS mapping has been reviewed by various authors (e.g. Andrew et al., 2014; Crossman et al., 2013). ESS supply has been mapped at various scales (e.g. sub-national to global) using both direct and indirect techniques. Whether direct or indirect techniques should be used depends on the information needs and characteristics of the ESS of interest (Andrew et al., 2014). EO-based methods can improve ESS supply estimates through their ability to depict subtle spatial variations in the plant functional traits and soil properties known to influence the supply of many services (Andrew et al., 2014).

It is worth noting that apart from microwave imagery, EO has limited capability for penetrating the vegetation canopy to extract useful information about any lower strata such as herbs or shrubs when the overstory is dense (Nagendra, 2001). Similarly, EO is incapable of providing direct information on below ground components of the ecosystems; these must be inferred from above ground data (Feng et al., 2010). EO-based assessments may therefore only provide a partial picture of diversity and soil-based ESS, for example, restricting the potential to comprehensively assess ESS provision. This restriction of EO data highlights the importance of creating an integrated framework of EO and in situ data collection, not only to provide data for training and validation of EO products, but also to provide information on the areas that cannot be adequately assessed using EO.

\section{Discussion}

When using satellite data there are a number of considerations to take into account, including data gaps and image frequency. The availability, or lack thereof, of cloud-free images at suitable timescales is a critical challenge for many EO-based applications. Research suggests revisit frequencies ranging from $<1$ day to exactly 8 days (depending on location and time of year) would be necessary to achieve a view at least $70 \%$ clear within 8 days (Whitcraft et al., 2015). Previously, such revisit times were only achievable using coarse resolution data, which restricted the ability to perform fine-scale assessments of agricultural intensity. However, the number of medium-high resolution satellites has increased in recent years, for example with the launch of those within the Copernicus Programme. Combining freely available data from these various systems increases the number of images available for each point on earth. For example, by combining Landsat 8 with Sentinel-2A/B data, one image should be available every 3 days on average (Li and Roy, 2017), increasing the likelihood of obtaining sufficient cloud-free images. The creation of a Harmonised Landsat and Sentinel-2 reflectance data set (Claverie et al., 2018) alongside the free availability of 
Sentinel-1 data (Torres et al., 2012), which is not affected by cloud cover, the launch of satellite fleets (e.g. Planet Labs) and the increased use of UAVs are all helping to mitigate the impact of cloud-cover on EO-based applications.

Various techniques also exist to deal with gaps and noise in the data. These techniques include pixel unmixing (Zhang et al., 2017), data fusion (Gevaert and García-Haro, 2015; Senf et al., 2015; Wang and Atkinson, 2018), best-pixel selection (Griffiths et al., 2013; Hermosilla et al., 2018), data interpolation (Inglada et al., 2017; Vuolo et al., 2017), climatology fitting (Verger et al., 2013), temporal smoothing (Kandasamy et al., 2013; Shao et al., 2016; Tan et al., 2011) and temporal aggregation (Loveland et al., 2000). The introduction of computing platforms such as Google Earth Engine (Gorelick et al., 2017) allows these complex algorithms to be applied to large volumes of data, by providing access to greater computing power and satellite datasets on a global-scale (Carrasco et al., 2019). These platforms greatly reduce the time and cost associated with image processing, which increases the viability of such gap-filling techniques and facilitates development of new approaches for producing necessary cloud-free datasets.

Another key issue is the development of universally applicable EO-based monitoring techniques. Methods, such as crop yield models, that rely on largely location- and sensor-specific empirical relationships to retrieve indicators are common within many EO-based applications. However, lack of historic and large-scale in situ data for all areas limits the potential for calibration and validation of such methods (Doraiswamy et al., 2005; Estel et al., 2016). Suitable validation and calibration data may exist, but availability to researchers may be restricted due to commercial confidentiality, among other factors. The frequent reliance on empirical relationships, and lack of in situ data for all locations, limits the transportability of these methods to different sensors and study areas (Andrew et al., 2014; Li et al., 2014); development of more generalised models is required. Less empirical models still often have parameters that need calibrating, to enable them to be applied appropriately to new geographical areas, new crops, or new animal species.

The creation of generic, transferable and widely applicable models must consider a variety of factors including the scale and resolution over which specific relationships apply (Foody, 2004; Gillespie et al., 2008) (Gustafson, 1998) and the variation in the relative dominance of different variables within space and time (e.g. (Prasad et al., 2006). Additionally, the impact that landscape characteristics can have on the accuracy with which indicators can be retrieved needs to be considered. For example, the size, shape and orientation of objects, such as narrow rivers (Sulistioadi et al., 2015) and small habitat patches (Luoto et al., 2002), can limit their detectability. Underlying environmental conditions can also affect the accuracy with which variables such as crop residue (Pacheco and McNairn, 2010) and soil moisture (Lakhankar et al., 2009) can be retrieved. As such, comparison over diverse agricultural environments must be done with care, and with an understanding of the underlying differences in landscape characteristics.

To create models that can be widely applied, either empirical models are required that are integrated with ground collection efforts (e.g. Boryan et al., 2011), or model-based methods that need no calibration to be applied to new areas must be developed. In practice, the solution is likely to involve a mixture of these two options.

\subsection{Opportunities for an EO-based SI Assessment System}

Despite the potential importance of SI for securing future food supplies, methods for assessing the success of SI attempts are currently lacking. Gaps in these assessments arise, in part, due to the reliance on data that typically lacks the temporal and spatial coverage and resolution necessary to make a reliable assessment of SI. EO provides a range of opportunities for the development of an operational SI monitoring system that can be applied from field-scale to global-scale, at various temporal resolutions. The global coverage and consistency (e.g. image resolution, data quality and processing standards) afforded by EO data facilitates multi-scale analysis and comparisons between countries with diverse farming practices and field data availability. Additionally, the ability to derive different indicators from the same EO data sources ensures coherence between measures of sustainability 
and intensification; this facilitates easier, more reliable integration of indicators into an assessment framework. The availability of long-term data (30-40 years from Landsat data archive) and repeat measurements allows the establishment of a baseline against which long-term and short-term changes can be assessed. Combined with the increasing availability of free satellite data, these factors allow a more flexible, adaptable and cost-effective approach to SI assessment to be developed. Furthermore, the ease, speed and efficiency with which assessments can be conducted is increased by the digital nature of EO data which allows, for example, simpler data input and processing. Recent advances in computer processing power/capability, such as cloud computing, further improve the situation, enhancing our ability to process and analyse large datasets.

As this review demonstrates, the basic EO-based assessment techniques for indicators of environmental sustainability and agricultural intensity are already established. This means that future work can focus on amalgamating existing work and creating a framework to integrate relevant indicators. An important step in the development of a comprehensive EO-based assessment framework is the creation of a set "Essential Sustainable Intensification Variables" (ESIVs) to form the basis for a global monitoring program. Having a set of "essential variables" helps to prioritise efforts by outlining a minimum set of essential measurements (Pereira et al., 2013) required to capture major dimensions of agricultural and environmental change, allowing the sustainability of intensification to be assessed. The development of this list should build on the selection frameworks created for the Essential Climate Variables (ECVs) and Essential Biodiversity Variables (EBVs) of the Global Framework for Climate Services (GCFS) and Group on Earth Observations Biodiversity Observation Network (GEO BON) respectively. In brief, variable selection will require an open, inter-disciplinary process, involving the engagement of scientific, policy and other communities (Pereira et al., 2013). This will ensure it builds on existing activities such as the ECVs, EBVs and GEOGLAM. Variables should be identified based on key criteria such as relevance, feasibility, scalability, temporal sensitivity and cost effectiveness (Bojinski et al., 2014; Pereira et al., 2013). As Pettorelli et al. (2016) highlight for the ECVs and EBVs, the identification of suitable ESIVs will be an evolving process. The list of indicators will need to be periodically updated as technology advances, and as sensor availability and observation priorities change. Table 3 provides an example list of possible "essential" EO-based indicators. This list is based on indicators already incorporated in the EBVs and ECVs, and previous SI frameworks including the Sustainable Intensification Assessment Framework (Musumba et al., 2017).

\begin{tabular}{|c|c|c|c|}
\hline $\begin{array}{l}\text { ESIV } \\
\text { examples }\end{array}$ & Relevance & Existing Operational Products & $\begin{array}{l}\text { Ideal Product } \\
\text { Coverage }\end{array}$ \\
\hline \multicolumn{4}{|c|}{ Agricultural intensity } \\
\hline Crop type & $\begin{array}{l}\text { Essential product required to be able to } \\
\text { accurately monitor/derive crop yield and area, } \\
\text { but not an indicator in its own right. }\end{array}$ & $\begin{array}{l}\text { - OneSoil crop-type map 2016, 2017, } \\
2018 \\
\text { - Country-level products e.g. CEH Land } \\
\text { Cover plus: Crops } 2015 \text { (partial } \\
\text { coverage), 2016, 2017, } 2018 \text { (GB) }\end{array}$ & $\begin{array}{l}\text { - Annually } \\
\text { (possibly more } \\
\text { often for multi- } \\
\text { cropping systems) }\end{array}$ \\
\hline Crop yield & Needed to quantify agricultural intensity & $\begin{array}{l}\text { Currently no operational products } \\
\text { exist }\end{array}$ & - Annually \\
\hline $\begin{array}{l}\text { Crop yield } \\
\text { gap }\end{array}$ & $\begin{array}{l}\text { Needed to help identify areas that could be } \\
\text { farmed more intensively }\end{array}$ & Currently no operational products & - Annually \\
\hline $\begin{array}{l}\text { Cropping } \\
\text { area }\end{array}$ & Needed to quantify agricultural extent & $\begin{array}{l}\text { - OneSoil crop-type map 2016, 2017, } \\
2018 \\
\text { Crops are a subset of land cover maps: } \\
\text { - Country-specific Land Cover maps } \\
\text { e.g. CEH GB Land Cover Map } 201530 \mathrm{~m} \\
\text { - Pan-European: CORINE Land Cover } \\
\text { minimum mapping unit 25ha } \\
\text { - Global land cover map 30m (Chen et } \\
\text { al., 2015) }\end{array}$ & - Annually \\
\hline
\end{tabular}


NPP/GPP* Provides a measure of the health/degradation of the ecosystem; underpins all production-based ecosystem services.
- NASA MODIS yearly $500 \mathrm{~m} / 1 \mathrm{~km} 2000$ to present

- Copernicus GDMP 10-day 1km 1999 to present \& 10-day 300 m 2014 to present

- Patches of natural/seminatural habitat within the farmed area - Annually

$\begin{array}{ll}\text { Soil } & \text { Indicator of soil quality. Increased fertiliser use } \\ \text { moisture } \times & \text { can increase water consumption and deplete soil } \\ & \text { moisture. A decline in soil moisture may be an } \\ & \text { indication of unsustainable intensification. }\end{array}$

- SMOS daily/3-day/10-day/monthly 15/25km 2009 to present

- Farmed area

- Copernicus METOP/ASCAT daily $0.01^{\circ}$

2007 to present

- Copernicus Sentinel-1 daily $1 \mathrm{~km}$ 2015-2017 (Europe only)

\begin{tabular}{|c|c|c|c|}
\hline $\begin{array}{l}\text { Soil } \\
\text { erosion }\end{array}$ & $\begin{array}{l}\text { Removal of interstitial features (e.g. hedgerows) } \\
\text { and increased runoff (due to soil compaction) } \\
\text { increases soil erosion. An increase in soil erosion } \\
\text { may be an indication of unsustainable } \\
\text { intensification. }\end{array}$ & $\begin{array}{l}\text { Currently no operational products } \\
\text { exist }\end{array}$ & $\begin{array}{l}\text { - Farmed area } \\
\text { plus surrounding } \\
\text { area } \\
\text { - Annually }\end{array}$ \\
\hline $\begin{array}{l}\text { Soil } \\
\text { organic } \\
\text { carbon }{ }^{\times}\end{array}$ & $\begin{array}{l}\text { Indicator of soil quality. Increased irrigation and } \\
\text { soil erosion lead to a decline in organic matter } \\
\text { content. A decrease in soil organic carbon may } \\
\text { be an indication of unsustainable intensification. }\end{array}$ & $\begin{array}{l}\text { Currently no operational products } \\
\text { exist }\end{array}$ & $\begin{array}{l}\text { - Farmed area } \\
\text { - Annually }\end{array}$ \\
\hline $\begin{array}{l}\text { Water } \\
\text { clarity/ } \\
\text { turbidity }\end{array}$ & $\begin{array}{l}\text { Increased agrochemical inputs and increased soil } \\
\text { erosion reduce water quality. Lower } \\
\text { clarity/higher turbidity may be an indication of } \\
\text { unsustainable intensification. }\end{array}$ & $\begin{array}{l}\text { - Copernicus ENVISAT/MERIS 10-day } \\
300 \mathrm{~m} / 1 \mathrm{~km} 2002 \text { to } 2012 \\
\text { - Copernicus Sentinel-3/OLCI 10-day } \\
300 \mathrm{~m} / 1 \mathrm{~km} 2017 \text { to present }\end{array}$ & $\begin{array}{l}\text { - Nearby water } \\
\text { bodies } \\
\text { - Annually }\end{array}$ \\
\hline $\begin{array}{l}\text { Landscape } \\
\text { structure* }\end{array}$ & $\begin{array}{l}\text { Removal of interstitial features e.g. hedges and } \\
\text { increased field sizes cause simplification of } \\
\text { habitat structure and loss of ecosystem } \\
\text { connectivity. Knock-on effect on species } \\
\text { populations and diversity (e.g. birds). }\end{array}$ & $\begin{array}{l}\text { - Country-specific Land Cover maps } \\
\text { e.g. CEH GB Land Cover Map } 201530 \mathrm{~m} \\
\text { - Pan-European: CORINE Land Cover } \\
\text { Minimum mapping unit 25ha } \\
\text { - Global land cover map 30m (Chen et } \\
\text { al., 2015) }\end{array}$ & $\begin{array}{l}\text { - Surrounding } \\
\text { area } \\
\text { - Annually }\end{array}$ \\
\hline $\begin{array}{l}\text { Species } \\
\text { richness/ } \\
\text { diversity* }\end{array}$ & $\begin{array}{l}\text { Increase in agrochemical inputs, irrigation and } \\
\text { landscape structure simplification alter species } \\
\text { composition. A decrease in species richness and } \\
\text { diversity may be an indication of unsustainable } \\
\text { intensification. }\end{array}$ & $\begin{array}{l}\text { - European Atlas of Forest Tree Species } \\
1 \mathrm{~km}\end{array}$ & $\begin{array}{l}\text { - Surrounding } \\
\text { area } \\
\text { - Annually } \\
\text { - Flora and fauna } \\
\text { species }\end{array}$ \\
\hline
\end{tabular}

Table 3: Examples of possible Essential Sustainable Intensification Indicators (ESIV). *indicates variables which are already included within the list of EBVs. ${ }^{\times}$indicates variables which are already included within the list of ECVs. NB: the OneSoil data is not currently available for download, but it shows the potential for the creation of an operational global crop-type map.

Once a comprehensive list of ESIVs has been generated, careful consideration must be given to the selection of appropriate methods to assess each variable. This could be achieved by adopting an open process of algorithm inter-comparison and selection similar to that used by ESA in their Climate Change Initiative (Hollmann et al., 2013), 2013) and the Sen2-Agri project (Bontemps et al., 2015). To allow reliable comparison of different algorithms and to ensure their relevance at local scales and widely varying agricultural systems at global scales, an open test dataset similar to that used in the Sen2-Agri project should be developed. This dataset was created through acquisition of satellite and in situ data from the same season over sites representative of global agricultural system diversity (Bontemps et al., 2015). Application of the potential algorithms to this data set ensured an objective and transparent algorithm selection method, which should be mirrored in the creation of the ESIV data products.

An important part of building the ESIV products will be a comprehensive assessment of the associated uncertainties and a clear communication of these uncertainties to the end-user. Kissling et al. (2018) set out a workflow of 11 steps used to operationalise the process of building EBV data products, including the quantification and communication of uncertainties in terms of data, model algorithms and parameters. Consideration must be 
given to uncertainties associated with the underlying raw data, from both satellite and in situ sources, and from processing methods (e.g. gap-filling techniques) and models applied to this data. Kissling et al. (2018) highlight the need to develop high-throughput processing tools for quantifying uncertainties; the same will be true for the ESIVs.

Another key element will be the development of a framework through which the ESIVs can be utilised to provide an assessment of the sustainability of agricultural intensification. Previous assessment frameworks have utilised indicators in a number of ways: (i) individually, expressed in units, (ii) as part of a set, or (iii) in a composite index, whereby scores of individual indicators are combined into a single, dimensionless number, or sustainability score (Dantsis et al., 2010; Farrell and Hart, 1998; Mitchell et al., 1995; Van Passel and Meul, 2012). An example of a widely used composite indicator for sustainability assessment is the Ecological Footprint which combines various indicator footprints including carbon, forest, crop land, \& built up land footprint to provide a measurement of human demand for land and water areas (Toderoiu, 2010 in Čuček et al., 2012; Galli et al., 2012). Some studies choose not to aggregate their indicators, adopting instead the use of sustainability polygons, webs and radars, which removes the need for aggregation across different scales by displaying scores for different index components simultaneously (Rigby et al., 2001). A decision about the best way to utilise the ESIVs within the proposed EO-based assessment framework will require consultation with researchers and intended users.

The success of the proposed EO-based assessment framework will rely heavily on the development of an integrated system of routine collection and provision of in situ data. In situ data is required to perform a number of roles including calibration and validation of EO-derived products and assessment of elements of the environment that cannot efficiently/effectively be monitored using EO data, for example below-ground properties and processes. A comprehensive assessment of SI will also require economic and social data that cannot be provided by EO.

An EO-based assessment framework could be implemented at different scales and at different levels of detail. For example at country-level, assessments are more likely to have access to environmental and farming data sets that would enable more detailed assessments of environmental sustainability. National-scale assessments are also more likely to have access to additional economic and social data that would enable more comprehensive SI assessments to be conducted. However, globally less detailed in situ data is likely to be available, although programs such as GEOSS and GEOGLAM have shown that good quality reference data sets can be collected for some areas to help the development of more global solutions. The development of detailed nationally-based methods, and less detailed globally-based methods, is likely to occur in different ways. A globally-based system would develop most sensibly through integration with existing global initiatives such as GEOSS, which is already generating products capable of agricultural and environmental monitoring. Whereas national-scale solutions are likely to develop from existing country-level environmental and agricultural monitoring schemes. However, for both the global and national-scale, the more integrated the EO and other strands of environmental monitoring are the better system will be.

\section{Conclusion}

One element of meeting the future food demands of a growing population, with shifting food consumption patterns, will be the intensification of agricultural production. To ensure long term environmental degradation is avoided, any increases in food production must be undertaken in a sustainable manner. The lack of any prescribed methods of sustainable intensification mean that to successfully achieve this goal a comprehensive method of assessing the sustainability of intensification endeavours must be developed. Various frameworks exist at present; however, these commonly rely on traditional data sources that do not provide adequate coverage, resolution, or frequency of data to generate reliable results for all agricultural systems. The potential for an EO-based assessment system is clear, with an extensive body of research into EO methods for monitoring earth surface properties and their spatial and temporal variation. 
The element that is currently missing is a system for combining these indicators to provide a comprehensive assessment of the sustainability of agricultural intensification. Such a system could build on the approaches used to develop the EBVs and ECVs and global agricultural monitoring schemes such as GEOGLAM. Determining the optimum format for this system will require a multi-disciplinary, multi-organisation working group involving farmers, researchers, government bodies and other stakeholders.

Irrespective of the exact nature of the final system, EO offers the opportunity to obtain more spatially and temporally representative data, over scales and resolutions unobtainable with conventional data collection methods. An EO-based system, however, does not exclude the need for in situ data, rather it will supplement current systems facilitating more efficient and consistent multi-scale assessments over a range of temporal resolutions at a lower cost. Integration of EO and in situ data on national and global scales, will be provide a step change in our ability to provide regular, consistent and timely assessments. This is essential if we are to meet future production demands without causing significant, irreparable damage to the environment.

\section{Acknowledgements}

MH was funded by Lancaster University through a Lancaster Environment Centre PhD Studentship as part of the Graduate School for the Environment. CR was supported by research programme NE/NO18125/1 LTS-M ASSIST Achieving Sustainable Agricultural Systems, funded by NERC and BBSRC.

Declarations of interest: none

\section{References}

Allahyari, M.S., Masouleh, Z.D., Koundinya, V., 2016. Implementing Minkowski fuzzy screening, entropy, and aggregation methods for selecting agricultural sustainability indicators. Agroecol. Sustain. Food Syst. 40, 277294. doi:10.1080/21683565.2015.1133467

Andrew, M.E., Wulder, M.A., Nelson, T.A., 2014. Potential contributions of remote sensing to ecosystem service assessments. Prog. Phys. Geogr. 38, 1-26. doi:10.1177/0309133314528942

Balbi, S., del Prado, A., Gallejones, P., Geevan, C.P., Pardo, G., Pérez-Miñana, E., Manrique, R., Hernandez-Santiago, C., Villa, F., 2015. Modeling trade-offs among ecosystem services in agricultural production systems. Environ. Model. Softw. 72, 314-326. doi:10.1016/j.envsoft.2014.12.017

Barnes, A.P., Thomson, S.G., 2014. Measuring progress towards sustainable intensification: How far can secondary data go? Ecol. Indic. 36, 213-220. doi:10.1016/j.ecolind.2013.07.001

Barnes, E.M., Baker, M.G., 2000. Multispectral data for mapping soil texture: possibilities and limitations. Appl. Eng. Agric. 16, 731-741. doi:10.13031/2013.5370

Benton, T.G., Vickery, J.A., Wilson, J.D., 2003. Farmland biodiversity: Is habitat heterogeneity the key? Trends Ecol. Evol. 18, 182-188. doi:10.1016/S0169-5347(03)00011-9

Binder, C.R., Feola, G., Steinberger, J.K., 2010. Considering the normative, systemic and procedural dimensions in indicator-based sustainability assessments in agriculture. Environ. Impact Assess. Rev. 30, 71-81. doi:10.1016/j.eiar.2009.06.002

Binder, C.R., Wiek, A., 2006. The role of transdisciplinary processes in sustainability assessment of agricultural systems, in: Häni, F.J., Pintér, L., Herren, H.R. (Eds.), Sustainable Agriculture: From Principles to Common Practice. Proceedings and Outputs of the First Symposium of the International Forum on Assessing Sustainability in Agriculture (INFASA), March 16, 2006, Bern, Switzerland. International Institute for Sustainable Development, pp. 33-48.

Bingfang, W., 2006. Introduction of China Crop Watch system with remote sensing, in: ISPRS Archives. XXXVI-8/W48: 
Remote Sensing Support to Crop Yield Forecast and Area Estimates. Stresa, Italy, pp. 15-18.

Biradar, C.M., Xiao, X., 2011. Quantifying the area and spatial distribution of double-and triple-cropping croplands in India with multi-temporal MODIS imagery in 2005. Int. J. Remote Sens. 32, 367-386. doi:10.1080/01431160903464179

Bojinski, S., Verstraete, M., Peterson, T.C., Richter, C., Simmons, A., Zemp, M., 2014. The Concept of Essential Climate Variables in Support of Climate Research, Applications, and Policy. Bull. Am. Meteorol. Soc. 95, 1431-1443. doi:10.1175/bams-d-13-00047.1

Bommarco, R., Kleijn, D., Potts, S.G., 2013. Ecological intensification: Harnessing ecosystem services for food security. Trends Ecol. Evol. 28, 230-238. doi:10.1016/j.tree.2012.10.012

Bontemps, S., Arias, M., Cara, C., Dedieu, G., Guzzonato, E., Hagolle, O., Inglada, J., Matton, N., Morin, D., Popescu, R., Rabaute, T., Savinaud, M., Sepulcre, G., Valero, S., Ahmad, I., Bégué, A., Wu, B., de Abelleyra, D., Diarra, A., Dupuy, S., French, A., Akhtar, I. ul H., Kussul, N., Lebourgeois, V., Page, M. Le, Newby, T., Savin, I., Verón, S.R., Koetz, B., Defourny, P., 2015. Building a data set over 12 globally distributed sites to support the development of agriculture monitoring applications with Sentinel-2. Remote Sens. 7, 16062-16090. doi:10.3390/rs71215815

Boryan, C., Yang, Z., Mueller, R., Craig, M., 2011. Monitoring US agriculture: The US department of agriculture, national agricultural statistics service, cropland data layer program. Geocarto Int. 26, 341-358. doi:10.1080/10106049.2011.562309

Buckwell, A., Nordang Uhre, A., Williams, A., Poláková, J., H Blum, W.E., Schiefer, J., Lair, G.J., Heissenhuber, A., Schieß I, P., Krämer, C., Haber, W., 2014. The Sustainable Intensification of European Agriculture. A Review Sponsored by the RISE Foundation.

Campbell, B.M., Thornton, P., Zougmoré, R., van Asten, P., Lipper, L., 2014. Sustainable intensification: What is its role in climate smart agriculture? Curr. Opin. Environ. Sustain. 8, 39-43. doi:10.1016/j.cosust.2014.07.002

Carrasco, L., O'Neil, A.W., Daniel Morton, R., Rowland, C.S., 2019. Evaluating combinations of temporally aggregated Sentinel-1, Sentinel-2 and Landsat 8 for land cover mapping with Google Earth Engine. Remote Sens. 11, 288. doi:10.3390/rs11030288

Caviglia, O.P., Andrade, F.H., 2010. Sustainable Intensification of Agriculture in the Argentinean Pampas: Capture and Use Efficiency of Environmental Resources. Am. J. Plant Sci. Biotechnol. 3, 1-8.

Claverie, M., Ju, J., Masek, J.G., Dungan, J.L., Vermote, E.F., Roger, J.C., Skakun, S. V., Justice, C., 2018. The Harmonized Landsat and Sentinel-2 surface reflectance data set. Remote Sens. Environ. 219, 145-161. doi:10.1016/j.rse.2018.09.002

Costanza, R., Mageau, M., 1999. What is a healthy ecosystem? Aquat. Ecol. 33, 105-115. doi:10.1023/A:1009930313242

Crossman, N.D., Burkhard, B., Nedkov, S., Willemen, L., Petz, K., Palomo, I., Drakou, E.G., Martín-Lopez, B., McPhearson, T., Boyanova, K., Alkemade, R., Egoh, B., Dunbar, M.B., Maes, J., 2013. A blueprint for mapping and modelling ecosystem services. Ecosyst. Serv. 4, 4-14. doi:10.1016/j.ecoser.2013.02.001

Crowder, D.W., Jabbour, R., 2014. Relationships between biodiversity and biological control in agroecosystems: Current status and future challenges. Biol. Control 75, 8-17. doi:10.1016/j.biocontrol.2013.10.010

Čuček, L., Klemeš, J.J., Kravanja, Z., 2012. A review of footprint analysis tools for monitoring impacts on sustainability. J. Clean. Prod. 34, 9-20. doi:10.1016/j.jclepro.2012.02.036

Dantsis, T., Douma, C., Giourga, C., Loumou, A., Polychronaki, E.A., 2010. A methodological approach to assess and compare the sustainability level of agricultural plant production systems. Ecol. Indic. 10, 256-263. doi:10.1016/j.ecolind.2009.05.007

Davis, F.W., Seo, C., Zielinski, W.J., 2007. Regional variation in home-range-scale habitat models for fisher (Martes 
pennanti) in California. Ecol. Appl. 17, 2195-2213. doi:10.1890/06-1484.1

Dietrich, J.P., Schmitz, C., Müller, C., Fader, M., Lotze-Campen, H., Popp, A., 2012. Measuring agricultural land-use intensity - A global analysis using a model-assisted approach. Ecol. Modell. 232, 109-118. doi:10.1016/j.ecolmodel.2012.03.002

Dillon, E.J., Hennessy, T., Buckley, C., Donnellan, T., Hanrahan, K., Moran, B., Ryan, M., 2016. Measuring progress in agricultural sustainability to support policy-making. Int. J. Agric. Sustain. 14, 31-44. doi:10.1080/14735903.2015.1012413

Dillon, E.J., Hennessy, T., Hynes, S., 2010. Assessing the sustainability of Irish agriculture. Int. J. Agric. Sustain. 8, 131147. doi:10.3763/ijas.2009.0044

Donald, P.F., Green, R.E., Heath, M.F., 2001. Agricultural intensification and the collapse of Europe's farmland bird populations. Proc. R. Soc. B 268, 25-29. doi:10.1098/rspb.2000.1325

Doraiswamy, P.C., Sinclair, T.R., Hollinger, S., Akhmedov, B., Stern, A., Prueger, J., 2005. Application of MODIS derived parameters for regional crop yield assessment. Remote Sens. Environ. 97, 192-202. doi:10.1016/j.rse.2005.03.015

Doran, J.W., Zeiss, M.R., 2000. Soil health and sustainability: managing the biotic component of soil quality. Appl. Soil Ecol. 15, 3-11. doi:10.1016/S0929-1393(00)00067-6

Egorov, A. V., Roy, D.P., Zhang, H.K., Li, Z., Yan, L., Huang, H., 2019. Landsat 4, 5 and 7 (1982 to 2017) Analysis Ready Data (ARD) observation coverage over the conterminous United States and implications for terrestrial monitoring. Remote Sens. 11, 447. doi:10.3390/rs11040447

Elliott, J., Firbank, L.G., Drake, B., Cao, Y., Gooday, R., 2013. Exploring the Concept of Sustainable Intensification. ADAS/Firbank, LUPG Commissioned Report.

Estel, S., Kuemmerle, T., Levers, C., Baumann, M., Hostert, P., 2016. Mapping cropland-use intensity across Europe using MODIS NDVI time series. Environ. Res. Lett. 11. doi:10.1088/1748-9326/11/2/024015

European Commission, 2016. Monitoring Agriultural Resources (MARS) [WWW Document]. URL https://ec.europa.eu/jrc/en/mars (accessed 4.9.17).

FAO, 2014. SAFA Sustainability Assessment of Food and Agriculture Systems: Guidelines (Version 3.0). Rome.

FAO, 2013. SAFA (Sustainability Assessment of Food and Agriculture Systems) Indicators.

FAO, 2009. How to Feed the World in 2050.

http://www.fao.org/fileadmin/templates/wsfs/docs/expert_paper/How_to_Feed_the_World_in_2050.pdf.

FAO, 2004. The ethics of sustainable agricultural intensification, FAO Ethics Series 3. ftp://ftp.fao.org/docrep/fao/007/j0902e/j0902e00.pdf.

Farrell, A., Hart, M., 1998. What does sustainability really mean?: The search for useful indicators. Environ. Sci. Policy Sustain. Dev. 40, 4-31. doi:10.1080/00139159809605096

Feng, X., Fu, B., Yang, X., Lü, Y., 2010. Remote sensing of ecosystem services: An opportunity for spatially explicit assessment. Chinese Geogr. Sci. 20, 522-535. doi:10.1007/s11769-010-0428-y

Ferencz, C., Bognár, P., Lichtenberger, J., Hamar, D., Tarcsai, G., Timár, G., Molnár, G., Pásztor, S.Z., Steinbach, P., Székely, B., Ferencz, O.E., Ferencz-Árkos, I., 2004. Crop yield estimation by satellite remote sensing. Int. J. Remote Sens. 25, 4113-4149. doi:10.1080/01431160410001698870

Firbank, L.G., Elliott, J., Drake, B., Cao, Y., Gooday, R., 2013. Evidence of sustainable intensification among British farms. Agric. Ecosyst. Environ. 173, 58-65. doi:10.1016/j.agee.2013.04.010

Foley, J.A., Ruth DeFries, Gregory P. Asner, Carol Barford, Gordon Bonan, Stephen R. Carpenter, F. Stuart Chapin, 
Michael T. Coe, Gretchen C. Daily, Holly K. Gibbs, Joseph H. Helkowski, Tracey Holloway, Erica A. Howard, Christopher J. Kucharik, Chad Monfreda, Jonathan A. Patz, I. Colin Prentice, Navin Ramankutty, Snyder, P.K., 2005. Global consequences of land use. Science (80-. ). 309, 570-574.

Foody, G.M., 2004. Spatial nonstationarity and scale-dependency in the relationship between species richness and environmental determinants for the sub-Saharan endemic avifauna. Glob. Ecol. Biogeogr. 13, 315-320. doi:10.1111/j.1466-822X.2004.00097.x

Galli, A., Wiedmann, T., Ercin, E., Knoblauch, D., Ewing, B., Giljum, S., 2012. Integrating Ecological, Carbon and Water footprint into a "footprint Family" of indicators: Definition and role in tracking human pressure on the planet. Ecol. Indic. 16, 100-112. doi:10.1016/j.ecolind.2011.06.017

Garnett, T., Appleby, M.C., Balmford, A., Bateman, I.J., Benton, T.G., Bloomer, P., Burlingame, B., Dawkins, M., Dolan, L., Fraser, D., Herrero, M., Hoffman, I., Smith, P., Thornton, P.K., Toulmin, C., Vermeulen, S.J., Godfray, H.C.J., 2013. Sustainable intensification in agriculture: premises and policies. Science (80-. ). 341, 33-34. doi:10.1126/science.1234485

Garnett, T., Godfray, H.C.J., 2012. Sustainable intensification in agriculture: Navigating a course through competing food system priorities. A report on a workshop. Oxford, UK: Food Climate Research Network and the Oxford Martin Programme on the Future of Food, University of Oxford.

GEO, n.d. GEOGLAM [WWW Document]. URL http://www.geoglam.org/index.php/en/ (accessed 4.9.17).

Gevaert, C.M., García-Haro, F.J., 2015. A comparison of STARFM and an unmixing-based algorithm for Landsat and MODIS data fusion. Remote Sens. Environ. 156, 34-44. doi:10.1016/j.rse.2014.09.012

Gillespie, T.W., Foody, G.M., Rocchini, D., Giorgi, A.P., Saatchi, S., 2008. Measuring and modelling biodiversity from space. Prog. Phys. Geogr. 32, 203-221. doi:10.1177/0309133308093606

Godfray, H.C.J., Beddington, J.R., Crute, I.R., Haddad, L., Lawrence, D., Muir, J.F., Pretty, J., Robinson, S., Thomas, S.M., Toulmin, C., 2010. Food Security: The Challenge of Feeding 9 Billion People. Science (80-. ). 327, 812-818. doi:10.1126/science.1185383

Godfray, H.C.J., Garnett, T., 2014. Food security and sustainable intensification. Philos. Trans. R. Soc. B 369, 2012073. doi:10.1098/rstb.2012.0273

Gómez-Limón, J.A., Sanchez-Fernandez, G., 2010. Empirical evaluation of agricultural sustainability using composite indicators. Ecol. Econ. 69, 1062-1075. doi:10.1016/j.ecolecon.2009.11.027

Gons, H.J., Auer, M.T., Effler, S.W., 2008. MERIS satellite chlorophyll mapping of oligotrophic and eutrophic waters in the Laurentian Great Lakes. Remote Sens. Environ. 112, 4098-4106. doi:10.1016/j.rse.2007.06.029

Gorelick, N., Hancher, M., Dixon, M., Ilyushchenko, S., Thau, D., Moore, R., 2017. Google Earth Engine: Planetaryscale geospatial analysis for everyone. Remote Sens. Environ. 202, 18-27. doi:10.1016/j.rse.2017.06.031

Griffiths, G.H., Lee, J., 2000. Landscape pattern and species richness; regional scale analysis from remote sensing. Int. J. Remote Sens. 21, 2685-2704. doi:10.1080/01431160050110232

Griffiths, P., van der Linden, S., Kuemmerle, T., Hostert, P., 2013. A Pixel-Based Landsat Compositing Algorithm for Large Area Land Cover Mapping. IEEE J. Sel. Top. Appl. Earth Obs. Remote Sens. 6, 2088-2101. doi:10.1109/JSTARS.2012.2228167

Gustafson, E.J., 1998. Quantifying Landscape Spatial Pattern: What Is the State of the Art? Ecosystems 1, 143-156. doi:10.1007/s100219900011

Häni, F., Braga, F., Stämpfli, A., Keller, T., Fischer, M., Porsche, H., 2003. RISE, a tool for holistic sustainability assessment at the farm level. Int. Food Agribus. Manag. Rev. 6, 78-90.

Häni, F.J., Stämpfli, A., Gerber, T., Porsche, H., Thalmann, C., Studer, C., 2006. RISE: A tool for improving sustainability 
in agriculture - a case study with tea farms in southern India, in: Häni, F.J., Pintér, L., Herren, H.R. (Eds.), Sustainable Agriculture: From Principles to Common Practice. Proceedings and Outputs of the First Symposium of the International Forum on Assessing Sustainability in Agriculture (INFASA), March 16, 2006, Bern, Switzerland. International Institute for Sustainable Development, pp. 121-148.

Hein, L., 2014. Biophysical Modelling and Analysis of Ecosystem Services in an Ecosystem Accounting Context DRAFT. http://img.teebweb.org/wp-content/uploads/2017/01/ANCA-Tech-Guid-9.pdf.

Hermosilla, T., Wulder, M.A., White, J.C., Coops, N.C., Hobart, G.W., 2018. Disturbance-Informed Annual Land Cover Classification Maps of Canada's Forested Ecosystems for a 29-Year Landsat Time Series. Can. J. Remote Sens. 44, 67-87. doi:10.1080/07038992.2018.1437719

Herzog, F., Steiner, B., Bailey, D., Baudry, J., Billeter, R., Bukácek, R., De Blust, G., De Cock, R., Dirksen, J., Dormann, C.F., De Filippi, R., Frossard, E., Liira, J., Schmidt, T., Stöckli, R., Thenail, C., Van Wingerden, W., Bugter, R., 2006. Assessing the intensity of temperate European agriculture at the landscape scale. Eur. J. Agron. 24, 165-181. doi:10.1016/j.eja.2005.07.006

Hollmann, R., Merchant, C.J., Saunders, R., Downy, C., Buchwitz, M., Cazenave, A., Chuvieco, E., Defourny, P., de Leeuw, G., Forsberg, R., Holzer-Popp, T., Paul, F., Sandven, S., Sathyendranath, S., van Roozendael, M., Wagner, W., 2013. The ESA Climate Change Initiative: Satellite Data Records for Essential Climate Variables. Bull. Am. Meteorol. Soc. 94, 1541-1552. doi:10.1175/bams-d-11-00254.1

Honnay, O., Piessens, K., Van Landuyt, W., Hermy, M., Gulinck, H., 2003. Satellite based land use and landscape complexity indices as predictors for regional plant species diversity. Landsc. Urban Plan. 63, 241-250. doi:10.1016/S0169-2046(02)00194-9

Inglada, J., Vincent, A., Arias, M., Tardy, B., Morin, D., Rodes, I., 2017. Operational High Resolution Land Cover Map Production at the Country Scale Using Satellite Image Time Series. Remote Sens. 9, 95. doi:10.3390/rs9010095

Jackson, T.J., Chen, D., Cosh, M., Li, F., Anderson, M., Walthall, C., Doriaswamy, P., Hunt, E.R., 2004. Vegetation water content mapping using Landsat data derived normalized difference water index for corn and soybeans. Remote Sens. Environ. 92, 475-482. doi:10.1016/j.rse.2003.10.021

Kandasamy, S., Baret, F., Verger, A., Neveux, P., Weiss, M., 2013. A comparison of methods for smoothing and gap filling time series of remote sensing observations - application to MODIS LAI products. Biogeosciences 10, 4055-4071. doi:10.5194/bg-10-4055-2013

Kerr, J.T., Cihlar, J., 2003. Land use and cover with intensity of agriculture for Canada from satellite and census data. Glob. Ecol. Biogeogr. 12, 161-172. doi:10.1046/j.1466-822X.2003.00017.x

Kerr, J.T., Ostrovsky, M., 2003. From space to species: Ecological applications for remote sensing. Trends Ecol. Evol. 18, 299-305. doi:10.1016/S0169-5347(03)00071-5

Kissling, W.D., Ahumada, J.A., Bowser, A., Fernandez, M., Fernández, N., García, E.A., Guralnick, R.P., Isaac, N.J.B., Kelling, S., Los, W., McRae, L., Mihoub, J.B., Obst, M., Santamaria, M., Skidmore, A.K., Williams, K.J., Agosti, D., Amariles, D., Arvanitidis, C., Bastin, L., De Leo, F., Egloff, W., Elith, J., Hobern, D., Martin, D., Pereira, H.M., Pesole, G., Peterseil, J., Saarenmaa, H., Schigel, D., Schmeller, D.S., Segata, N., Turak, E., Uhlir, P.F., Wee, B., Hardisty, A.R., 2018. Building essential biodiversity variables (EBVs) of species distribution and abundance at a global scale. Biol. Rev. 93, 600-625. doi:10.1111/brv.12359

Kuemmerle, T., Erb, K., Meyfroidt, P., Müller, D., Verburg, P.H., Estel, S., Haberl, H., Hostert, P., Jepsen, M.R., Kastner, T., Levers, C., Lindner, M., Plutzar, C., Verkerk, P.J., van der Zanden, E.H., Reenberg, A., 2013. Challenges and opportunities in mapping land use intensity globally. Curr. Opin. Environ. Sustain. 5, 484-493. doi:10.1016/j.cosust.2013.06.002

Kuenzer, C., Ottinger, M., Wegmann, M., Guo, H., Wang, C., Zhang, J., Dech, S., Wikelski, M., 2014. Earth observation satellite sensors for biodiversity monitoring: potentials and bottlenecks. Int. J. Remote Sens. 35, 6599-6647. doi:10.1080/01431161.2014.964349 
Lakhankar, T., Ghedira, H., Temimi, M., Azar, A.E., Khanbilvardi, R., 2009. Effect of land cover heterogeneity on soil moisture retrieval using active microwave remote sensing data. Remote Sens. 1, 80-91. doi:10.3390/rs1020080

Lampkin, N.H., Pearce, B.D., Leake, A.R., Creissen, H., Gerrard, C.L., Girling, R., Lloyd, S., Padel, S., Smith, J., Smith, L.G., Vieweger, A., Wolfe, M.S., 2015. The Role of Agroecology in Sustainable Intensification. Report for the Land Use Policy Group. Organic Research Centre, Elm Farm and Game \& Wildlife Conservation Trust.

Lasne, Y., Paillou, P., Ruffié, G., Serradilla, C., Freeman, A., Farr, T., Mcdonald, K., Chapman, B., 2008. Effect of Salinity on the Dielectric Properties of Geological Materials: Implication for Soil Moisutre Detection by Means of Remote Sensing. IEEE Trans. Geosci. Remote Sens. 6, 1674-1688. doi:10.1109/TGRS.2008.916220

Li, J., Roy, D.P., 2017. A global analysis of Sentinel-2A, Sentinel-2B and Landsat-8 data revisit intervals and implications for terrestrial monitoring. Remote Sens. 9, 902. doi:10.3390/rs9090902

$\mathrm{Li}, \mathrm{Z}$., Guo, X., 2012. Detecting climate effects on vegetation in northern mixed rairie using NOAA AVHRR 1-km timeseries NDVI data. Remote Sens. 4, 120-134. doi:10.3390/rs4010120

Li, Z., Xu, D., Guo, X., 2014. Remote sensing of ecosystem health: opportunities, challenges, and future perspectives. Sensors 14, 21117-21139. doi:10.3390/s141121117

Loveland, T.R., Reed, B.C., Ohlen, D.O., Brown, J.F., Zhu, Z., Yang, L., Merchant, J.W., 2000. Development of a global land cover characteristics database and IGBP DISCover from $1 \mathrm{~km}$ AVHRR data. Int. J. Remote Sens. 21, 13031330. doi:10.1080/014311600210191

Luoto, M., Toivonen, T., Heikkinen, R.K., 2002. Prediction of total and rare plant species richness in agricultural landscapes from satellite images and topographic data. Landsc. Ecol. 17, 195-217. doi:10.1023/A:1020288509837

Mairota, P., Cafarelli, B., Didham, R.K., Lovergine, F.P., Lucas, R.M., Nagendra, H., Rocchini, D., Tarantino, C., 2015. Challenges and opportunities in harnessing satellite remote-sensing for biodiversity monitoring. Ecol. Inform. 30, 207-214. doi:10.1016/j.ecoinf.2015.08.006

Martinez, J.M., Guyot, J.L., Cochonneau, G., 2008. Monitoring of surface water quality in large rivers with satellite imagery - Application to the Amazon basin. www.iwra.org/congress/resource/abs649_article.pdf.

Matson, P.A., Parton, W.J., Power, A.G., Swift, M.J., 1997. Agricultural intensification and ecosystem properties. Science (80-. ). 277, 504-509. doi:10.1126/science.277.5325.504

Meeus, J.H.A., 1993. The transformation of agricultural landscapes in Western Europe. Sci. Total Environ. 129, 171190. doi:10.1016/0048-9697(93)90169-7

Mingwei, Z., Qingbo, Z., Zhongxin, C., Jia, L., Yong, Z., Chongfa, C., 2008. Crop discrimination in Northern China with double cropping systems using Fourier analysis of time-series MODIS data. Int. J. Appl. Earth Obs. Geoinf. 10, 476-485. doi:10.1016/j.jag.2007.11.002

Mitchell, G., May, A., Mcdonald, A., 1995. PICABUE: a methodological framework for the development of indicators of sustainable development. Int.J. Sustain. Dev. World Ecol 2, 104-123. doi:10.1080/13504509509469893

Moriondo, M., Maselli, F., Bindi, M., 2007. A simple model of regional wheat yield based on NDVI data. Eur. J. Agron. 26, 266-274. doi:10.1016/j.eja.2006.10.007

Mueller, N., Lewis, A., Roberts, D., Ring, S., Melrose, R., Sixsmith, J., Lymburner, L., McIntyre, A., Tan, P., Curnow, S., Ip, A., 2016. Water observations from space: Mapping surface water from 25years of Landsat imagery across Australia. Remote Sens. Environ. 174, 341-352. doi:10.1016/j.rse.2015.11.003

Musumba, M., Palm, C., Grabowski, P., Snapp, S.S., 2017. A Framework for Selecting and Analyzing Indicators of Sustainable intensification.

Myneni, R.B., Nemani, R.R., Running, S.W., 1997. Estimation of global leaf area index and absorbed PAR using 
radiative transfer models. IEEE Trans. Geosci. Remote Sens. 35, 1380-1393. doi:10.1109/36.649788

Nagendra, H., 2001. Using remote sensing to assess biodiversity. Int. J. Remote Sens. 22, 2377-2400. doi:10.1080/01431160117096

Newton, I., 2004. The recent declines of farmland bird populations in Britain: An appraisal of causal factors and conservation actions. Ibis (Lond. 1859). 146, 579-600. doi:10.1111/j.1474-919X.2004.00375.x

Niedertscheider, M., Kastner, T., Fetzel, T., Haberl, H., Kroisleitner, C., Plutzar, C., Erb, K.-H., 2016. Mapping and analysing cropland use intensity from a NPP perspective. Environ. Res. Lett. 11. doi:10.1088/17489326/11/1/014008

OneSoil, 2018. OneSoil [WWW Document]. URL https://onesoil.ai/en/ (accessed 4.8.19).

Pacheco, A., McNairn, H., 2010. Evaluating multispectral remote sensing and spectral unmixing analysis for crop residue mapping. Remote Sens. Environ. 114, 2219-2228. doi:10.1016/j.rse.2010.04.024

Pereira, H.M., Ferrier, S., Walters, M., Geller, G.N., Jongman, R.H.G., Scholes, R.J., Bruford, M.W., Brummitt, N., Butchart, S.H.M., Cardoso, A.C., Coops, N.C., Dulloo, E., Faith, D.P., Freyhof, J., Gregory, R.D., Heip, C., Höft, R., Hurtt, G., Jetz, W., Karp, D.S., McGeoch, M.A., Obura, D., Onoda, Y., Pettorelli, N., Reyers, B., Sayre, R., Scharlemann, J.P.W., Stuart, S.N., Turak, E., Walpole, M., Wegmann, M., 2013. Essential biodiversity variables. Science (80-. ). 339, 277-278. doi:10.1126/science.1229931

Pettorelli, N., Laurance, W.F., O’Brien, T.G., Wegmann, M., Nagendra, H., Turner, W., 2014. Satellite remote sensing for applied ecologists: Opportunities and challenges. J. Appl. Ecol. 51, 839-848. doi:10.1111/1365-2664.12261

Pettorelli, N., Wegmann, M., Skidmore, A., Mücher, S., Dawson, T.P., Fernandez, M., Lucas, R., Schaepman, M.E., Wang, T., O'Connor, B., Jongman, R.H.G., Kempeneers, P., Sonnenschein, R., Leidner, A.K., Böhm, M., He, K.S., Nagendra, H., Dubois, G., Fatoyinbo, T., Hansen, M.C., Paganini, M., de Klerk, H.M., Asner, G.P., Kerr, J.T., Estes, A.B., Schmeller, D.S., Heiden, U., Rocchini, D., Pereira, H.M., Turak, E., Fernandez, N., Lausch, A., Cho, M.A., Alcaraz-Segura, D., McGeoch, M.A., Turner, W., Mueller, A., St-Louis, V., Penner, J., Vihervaara, P., Belward, A., Reyers, B., Geller, G.N., 2016. Framing the concept of satellite remote sensing essential biodiversity variables: challenges and future directions. Remote Sens. Ecol. Conserv. 2, 122-131. doi:10.1002/rse2.15

Power, A.G., 2010. Ecosystem services and agriculture: tradeoffs and synergies. Philos. Trans. R. Soc. B 365, 29592971. doi:10.1098/rstb.2010.0143

Prasad, A.K., Chai, L., Singh, R.P., Kafatos, M., 2006. Crop yield estimation model for lowa using remote sensing and surface parameters. Int. J. Appl. Earth Obs. Geoinf. 8, 26-33. doi:10.1016/j.jag.2005.06.002

Pretty, J., 2008. Agricultural sustainability: concepts, principles and evidence. Philos. Trans. R. Soc. B 363, 447-465. doi:10.1098/rstb.2007.2163

Pretty, J., Bharucha, Z.P., 2014. Sustainable intensification in agricultural systems. Ann. Bot. 114, 1571-1596. doi:10.1093/aob/mcu205

Pretty, J., Toulmin, C., Williams, S., 2011. Sustainable intensification in African agriculture. Int. J. Agric. Sustain. 9, 524. doi:10.3763/ijas.2010.0583

Rasul, G., Thapa, G.B., 2004. Sustainability of ecological and conventional agricultural systems in Bangladesh: An assessment based on environmental, economic and social perspectives. Agric. Syst. 79, 327-351. doi:10.1016/S0308-521X(03)00090-8

Rigby, D., Woodhouse, P., Young, T., Burton, M., 2001. Constructing a farm level indicator of sustainable agricultural practice. Ecol. Econ. 39, 463-478. doi:10.1016/S0921-8009(01)00245-2

Rocchini, D., Balkenhol, N., Carter, G.A., Foody, G.M., Gillespie, T.W., He, K.S., Kark, S., Levin, N., Lucas, K., Luoto, M., Nagendra, H., Oldeland, J., Ricotta, C., Southworth, J., Neteler, M., 2010. Remotely sensed spectral

heterogeneity as a proxy of species diversity: Recent advances and open challenges. Ecol. Inform. 5, 318-329. 
doi:10.1016/j.ecoinf.2010.06.001

Rodrigues, G.S., Rodrigues, I.A., Buschinelli, C.C. de A., de Barros, I., 2010. Integrated farm sustainability assessment for the environmental management of rural activities. Environ. Impact Assess. Rev. 30, 229-239. doi:10.1016/j.eiar.2009.10.002

Roy, D.P., Ju, J., Kline, K., Scaramuzza, P.L., Kovalskyy, V., Hansen, M., Loveland, T.R., Vermote, E., Zhang, C., 2010. Web-enabled Landsat Data (WELD): Landsat ETM+ composited mosaics of the conterminous United States. Remote Sens. Environ. 114, 35-49. doi:10.1016/j.rse.2009.08.011

Roy, R., Chan, N.W., 2012. An assessment of agricultural sustainability indicators in Bangladesh: Review and synthesis. Environmentalist 32, 99-110. doi:10.1007/s10669-011-9364-3

Schut, M., van Asten, P., Okafor, C., Hicintuka, C., Mapatano, S., Nabahungu, N.L., Kagabo, D., Muchunguzi, P., Njukwe, E., Dontsop-Nguezet, P.M., Sartas, M., Vanlauwe, B., 2016. Sustainable intensification of agricultural systems in the Central African Highlands: The need for insitutional innovation. Agric. Syst. 145, 165-176. doi:10.1016/j.agsy.2016.03.005

Senf, C., Leitão, P.J., Pflugmacher, D., van der Linden, S., Hostert, P., 2015. Mapping land cover in complex Mediterranean landscapes using Landsat: Improved classification accuracies from integrating multi-seasonal and synthetic imagery. Remote Sens. Environ. 156, 527-536. doi:10.1016/j.rse.2014.10.018

Shao, Y., Lunetta, R.S., Wheeler, B., liames, J.S., Campbell, J.B., 2016. An evaluation of time-series smoothing algorithms for land-cover classifications using MODIS-NDVI multi-temporal data. Remote Sens. Environ. 174, 258-265. doi:10.1016/j.rse.2015.12.023

Shoshany, M., Goldshleger, N., Chudnovsky, A., 2013. Monitoring of agricultural soil degradation by remote-sensing methods: a review. Int. J. Remote Sens. 34, 6152-6181. doi:10.1080/01431161.2013.793872

Shriar, A.J., 2000. Agricultural intensity and its measurement in frontier regions. Agrofor. Syst. 49, 301-318. doi:10.1023/A:1006316131781

Singh, R., Semwal, D.P., Rai, A., Chhikara, R.S., 2002. Small area estimation of crop yield using remote sensing satellite data. Int. J. Remote Sens. 23, 49-56. doi:10.1080/01431160010014756

Singh, R.K., Murty, H.R., Gupta, S.K., Dikshit, A.K., 2009. An overview of sustainability assessment methodologies. Ecol. Indic. 9, 189-212. doi:10.1016/j.ecolind.2008.05.011

Smith, A., Snapp, S., Chikowo, R., Thorne, P., Bekunda, M., Glover, J., 2017. Measuring sustainable intensification in smallholder agroecosystems: A review. Glob. Food Sec. 12, 127-138. doi:10.1016/j.gfs.2016.11.002

Snapp, S.S., Grabowski, P., Chikowo, R., Smith, A., Anders, E., Sirrine, D., Chimonyo, V., Bekunda, M., 2018. Maize yield and profitability tradeoffs with social, human and environmental performance: Is sustainable intensification feasible? Agric. Syst. 162, 77-88. doi:10.1016/j.agsy.2018.01.012

Stein, A., Riley, J., Halberg, N., 2001. Issues of scale for environmental indicators. Agric. Ecosyst. Environ. 87, 215232. doi:10.1016/S0167-8809(01)00280-8

Stoate, C., Boatman, N.D., Borralho, R.J., Carvalho, C.R., de Snoo, G.R., Eden, P., 2001. Ecological impacts of arable intensification in Europe. J. Environ. Manage. 63, 337-365. doi:10.1006/jema.2001.0473

Sulistioadi, Y.B., Tseng, K.H., Shum, C.K., Hidayat, H., Sumaryono, M., Suhardiman, A., Setiawan, F., Sunarso, S., 2015. Satellite radar altimetry for monitoring small rivers and lakes in Indonesia. Hydrol. Earth Syst. Sci. 19, 341-359. doi:10.5194/hess-19-341-2015

Tan, B., Morisette, J.T., Wolfe, R.E., Gao, F., Ederer, G.A., Nightingale, J., Pedelty, J.A., 2011. An Enhanced TIMESAT Algorithm for Estimating Vegetation Phenology Metrics From MODIS Data. IEEE J. Sel. Top. Appl. Earth Obs. Remote Sens. 4, 361-371. doi:10.1109/JSTARS.2010.2075916 
Tebbs, E., Rowland, C., Smart, S., Maskell, L., Norton, L., 2017. Regional-Scale High Spatial Resolution Mapping of Aboveground Net Primary Productivity (ANPP) from Field Survey and Landsat Data: A Case Study for the Country of Wales. Remote Sens. 9, 801. doi:10.3390/rs9080801

Teillard, F., Allaire, G., Cahuzac, E., Léger, F., Maigné, E., Tichit, M., 2012. A novel method for mapping agricultural intensity reveals its spatial aggregation: Implications for conservation policies. Agric. Ecosyst. Environ. 149, 135-143. doi:10.1016/j.agee.2011.12.018

Teluguntla, P., Thenkabail, P., Oliphant, A., Xiong, J., Gumma, M.K., Congalton, R.G., Yadav, K., Huete, A., 2018. A 30$\mathrm{m}$ landsat-derived cropland extent product of Australia and China using random forest machine learning algorithm on Google Earth Engine cloud computing platform. ISPRS J. Photogramm. Remote Sens. 144, 325340. doi:10.1016/j.isprsjprs.2018.07.017

Temme, A.J.A.M., Verburg, P.H., 2011. Mapping and modelling of changes in agricultural intensity in Europe. Agric. Ecosyst. Environ. 140, 46-56. doi:10.1016/j.agee.2010.11.010

Tilman, D., Balzer, C., Hill, J., Befort, B.L., 2011. Global food demand and the sustainable intensification of agriculture. PNAS 108, 20260-20264. doi:10.1073/pnas.1116437108

Tilman, D., Cassman, K.G., Matson, P.A., Naylor, R., Polasky, S., 2002. Agricultural sustainability and intensive production practices. Nature 418, 671-677. doi:10.1038/nature01014

Torres, R., Snoeij, P., Geudtner, D., Bibby, D., Davidson, M., Attema, E., Potin, P., Rommen, B.Ö., Floury, N., Brown, M., Traver, I.N., Deghaye, P., Duesmann, B., Rosich, B., Miranda, N., Bruno, C., L'Abbate, M., Croci, R., Pietropaolo, A., Huchler, M., Rostan, F., 2012. GMES Sentinel-1 mission. Remote Sens. Environ. 120, 9-24. doi:10.1016/j.rse.2011.05.028

Trombetti, M., Riaño, D., Rubio, M.A., Cheng, Y.B., Ustin, S.L., 2008. Multi-temporal vegetation canopy water content retrieval and interpretation using artificial neural networks for the continental USA. Remote Sens. Environ. 112, 203-215. doi:10.1016/j.rse.2007.04.013

Turner, W., Rondinini, C., Pettorelli, N., Mora, B., Leidner, A.K., Szantoi, Z., Buchanan, G., Dech, S., Dwyer, J., Herold, M., Koh, L.P., Leimgruber, P., Taubenboeck, H., Wegmann, M., Wikelski, M., Woodcock, C., 2015. Free and open-access satellite data are key to biodiversity conservation. Biol. Conserv. 182, 173-176. doi:10.1016/j.biocon.2014.11.048

Turner, W., Spector, S., Gardiner, N., Fladeland, M., Sterling, E., Steininger, M., 2003. Remote sensing for biodiversity science and conservation. Trends Ecol. Evol. 18, 306-314. doi:10.1016/S0169-5347(03)00070-3

USDA FAS, n.d. GLAM - Global Agricultural Monitoring [WWW Document]. URL https://www.pecad.fas.usda.gov/glam.htm (accessed 4.9.17).

Van Cauwenbergh, N., Biala, K., Bielders, C., Brouckaert, V., Franchois, L., Garcia Cidad, V., Hermy, M., Mathijs, E., Muys, B., Reijnders, J., Sauvenier, X., Valckx, J., Vanclooster, M., Van der Veken, B., Wauters, E., Peeters, A., 2007. SAFE-A hierarchical framework for assessing the sustainability of agricultural systems. Agric. Ecosyst. Environ. 120, 229-242. doi:10.1016/j.agee.2006.09.006

Van Passel, S., Meul, M., 2012. Multilevel and multi-user sustainability assessment of farming systems. Environ. Impact Assess. Rev. 32, 170-180. doi:10.1016/j.eiar.2011.08.005

Verger, A., Baret, F., Weiss, M., Kandasamy, S., Vermote, E., 2013. The CACAO method for smoothing, gap filling, and characterizing seasonal anomalies in satellite time series. IEEE Trans. Geosci. Remote Sens. 51, 1963-1972. doi:10.1109/TGRS.2012.2228653

Vuolo, F., Ng, W.-T., Atzberger, C., 2017. Smoothing and gap-filling of high resolution multi-spectral time series: Example of Landsat data. Int. J. Appl. Earth Obs. Geoinf. 57, 202-213. doi:10.1016/j.jag.2016.12.012

Wagner, W., Naeimi, V., Scipal, K., Jeu, R., Martínez-Fernández, J., 2007. Soil moisture from operational meteorological satellites. Hydrogeol. J. 15, 121-131. doi:10.1007/s10040-006-0104-6 
Wang, K., Franklin, S.E., Guo, X., Cattet, M., 2010. Remote sensing of ecology, biodiversity and conservation: A review from the perspective of remote sensing specialists. Sensors 10, 9647-9667. doi:10.3390/s101109647

Wang, Q., Atkinson, P.M., 2018. Spatio-temporal fusion for daily Sentinel-2 images. Remote Sens. Environ. 204, 3142. doi:10.1016/j.rse.2017.10.046

Weiers, S., Bock, M., Wissen, M., Rossner, G., 2004. Mapping and indicator approaches for the assessment of habitats at different scales using remote sensing and GIS methods. Landsc. Urban Plan. 67, 43-65. doi:10.1016/S0169-2046(03)00028-8

Whitcraft, A.K., Becker-Reshef, I., Justice, C.O., 2015. A framework for defining spatially explicit earth observation requirements for a global agricultural monitoring initiative (GEOGLAM). Remote Sens. 7, 1461-1481. doi:10.3390/rs70201461

Wiek, A., Binder, C., 2005. Solution spaces for decision-making - A sustainability assessment tool for city-regions. Environ. Impact Assess. Rev. 25, 589-608. doi:10.1016/j.eiar.2004.09.009

Xiong, J., Thenkabail, P.S., Tilton, J.C., Gumma, M.K., Teluguntla, P., Oliphant, A., Congalton, R.G., Yadav, K., Gorelick, N., 2017. Nominal 30-m cropland extent map of continental Africa by integrating pixel-based and object-based algorithms using Sentinel-2 and Landsat-8 data on google earth engine. Remote Sens. 9, 1065. doi:10.3390/rs9101065

Yan, H., Xiao, X., Huang, H., Liu, J., Chen, J., Bai, X., 2014. Multiple Cropping Intensity in China Derived from Agrometeorolo- gical Observations and MODIS Data. Chinese Geogr. Sci. 24, 205-219. doi:10.1007/s11769-0130637-2

Zahm, F., Viaux, P., Vilain, L., Girardin, P., Mouchet, C., 2008. Assessing Farm Sustainability with the IDEA Method from the Concept of Agriculture Sustainability to Case Studies on Farms. Sustain. Dev. 16. doi:10.1002/sd.380

Zhang, Y., Atkinson, P.M., Li, X., Ling, F., Wang, Q., Du, Y., 2017. Learning-Based Spatial-Temporal Superresolution Mapping of Forest Cover with MODIS Images. IEEE Trans. Geosci. Remote Sens. 55, 600-614. doi:10.1109/TGRS.2016.2613140

Zhen, L., Routray, J.K., Zoebisch, M.A., Chen, G., Xie, G., Cheng, S., 2005. Three dimensions of sustainability of farming practices in the North China Plain: A case study from Ningjin County of Shandong Province, PR China. Agric. Ecosyst. Environ. 105, 507-522. doi:10.1016/j.agee.2004.07.012 


\section{Supplementary material}

\section{Contents}

\section{Page \\ number

\author{
Table/figure \\ number
}

2
Figure S1

Table S1

Table S3

Table S4

Table S5

Table S6

Table S7
Table S2

References for figure S1

Some of the key environmental impacts of various mechanisms of agricultural intensification with references. Reference numbers correspond to the list on pages 3-4.

\section{Description}

$$
\text { References for figure S1 }
$$

Examples of data sources and indicators used by various authors to investigate agricultural intensity.

Example EO-based methods used by researchers to assess agricultural intensity.

Example EO-based methods used by researchers to assess vegetation health.

Example EO-based methods used by researchers to assess soil quality and soil erosion/protection.

Example EO-based methods used by researchers to assess water quality and water availability.

Example EO-based methods used by researchers to assess biodiversity.

Example EO-based methods used by researchers to assess ecosystem health.

References for tables S1-S7 

the list on pages 3-4.

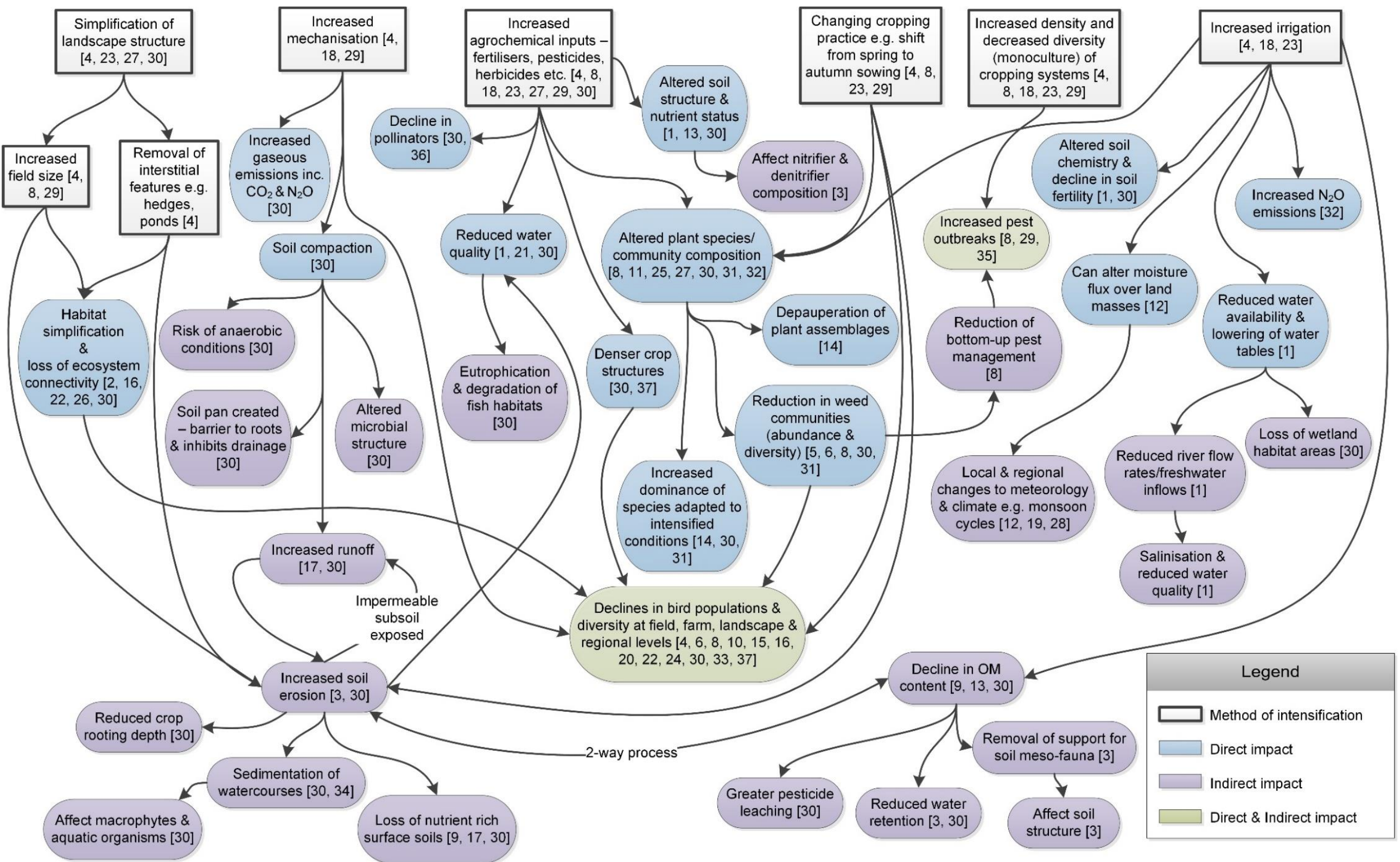




\section{References for figure $S 1$}

1. Alauddin, M., Quiggin, J., 2008. Agricultural intensification, irrigation and the environment in South Asia: Issues and policy options. Ecol. Econ. 65, 111-124. doi:10.1016/j.ecolecon.2007.06.004

2. Baum, K.A., Haynes, K.J., Dillemuth, F.P., Cronin, J.T., 2004. The matrix enhances the effectiveness of corridors and step ping stones. Reports Ecol. 85, 2671-2676. doi:10.1890/04-0500

3. Benckiser, G., 1997. Organic inputs and soil metabolism, in: Benckiser, G. (Ed.), Fauna in Soil Ecosystems: Recycling Processes, Nutrient Fluxes and Agricultural Production. Dekker, New York, pp. 7-62.

4. Benton, T.G., Vickery, J.A., Wilson, J.D., 2003. Farmland biodiversity: Is habitat heterogeneity the key? Trends Ecol. Evol. 18, 182-188. doi:10.1016/S0169-5347(03)00011-9

5. Blažek, P., Lepš, J., 2015. Victims of agricultural intensification: Mowing date affects Rhinanthus spp. regeneration and fruit ripening. Agric. Ecosyst. Environ. 211, 10-16. doi:10.1016/j.agee.2015.04.022

6. Campbell, L.H., Avery, M.I., Donald, P., Evans, A.D., Green, R.E., Wilson, J.D., 1997. A review of the indirect effects of pesticides on birds. JNCC Report No. 277. Peterborough.

7. Ciccolini, V., Bonari, E., Ercoli, L., Pellegrino, E., 2016. Phylogenetic and multivariate analyses to determine the effect of agricultural land-use intensification and soil physico-chemical properties on $\mathrm{N}$-cycling microbial communities in drained Mediterranean peaty soils. Biol. Fertil. Soils 52, 811-824. doi:10.1007/s00374-016-1121-9

8. Crowder, D.W., Jabbour, R., 2014. Relationships between biodiversity and biological control in agroecosystems: Current status and future challenges. Biol. Control 75, 8-17. doi:10.1016/j.biocontrol.2013.10.010

9. De Jong, S.M., Paracchini, M.L., Bertolo, F., Folving, S., Megier, J., De Roo, A.P.J., 1999. Regional assessment of soil erosion using the distributed model SEMMED and remotely sensed data. Catena 37, 291-308. doi:10.1016/50341-8162(99)00038-7

10. Donald, P.F., Green, R.E., Heath, M.F., 2001. Agricultural intensification and the collapse of Europe's farmland bird populations. Proc. R. Soc. B 268, 25-29. doi:10.1098/rspb.2000.1325

11. Dorrough, J., Scroggie, M.P., 2008. Plant responses to agricultural intensification. J. Appl. Ecol. 45, 1274-1283. doi:10.1111/j.1365-2664.2008.01501.x

12. Douglas, E.M., Beltrán-Przekurat, A., Niyogi, D., Pielke, R.A., Vörösmarty, C.J., 2009. The impact of agricultural intensification and irrigation on land-atmosphere interactions and Indian monsoon precipitation - A mesoscale modeling perspective. Glob. Planet. Change 67, 117-128. doi:10.1016/j.gloplacha.2008.12.007

13. Edwards, C.A., 1984. Changes in agricultural practice and their impact on soil organisms, in: Jenkins, D. (Ed.), Agriculture and the Environment. Proceedings of ITE Symposium no.13 Held at Monks Wood Experimental Station on 28-29 February and 1 March 1984. pp. 56-65.

14. Firbank, L.G., Petit, S., Smart, S., Blain, A., Fuller, R.J., 2008. Assessing the impacts of agricultural intensification on biodiversity: a British perspective. Philos. Trans. R. Soc. B Biol. Sci. 363, 777-787. doi:10.1098/rstb.2007.2183

15. Franke, A.C., Lotz, L.A.P., Van Der Burg, W.J., Van Overbeek, L., 2009. The role of arable weed seeds for agroecosystem functioning. Weed Res. 49, 131-141. doi:10.1111/j.1365-3180.2009.00692.x

16. Gabriel, D., Sait, S.M., Hodgson, J.A., Schmutz, U., Kunin, W.E., Benton, T.G., 2010. Scale matters: The impact of organic farming on biodiversity at different spatial scales. Ecol. Lett. 13, 858-869. doi:10.1111/j.1461-0248.2010.01481.x

17. Ganasri, B.P., Ramesh, H., 2016. Assessment of soil erosion by RUSLE model using remote sensing and GIS - A case study of Nethravathi Basin. Geosci. Front. 7, 953-961. doi:10.1016/j.gsf.2015.10.007

18. González-Estébanez, F.J., García-Tejero, S., Mateo-Tomás, P., Olea, P.P., 2011. Effects of irrigation and landscape heterogeneity on butterfly diversity in Mediterranean farmlands. Agric. Ecosyst. Environ. 144, 262-270. doi:10.1016/j.agee.2011.09.002

19. Gordon, L.J., Steffen, W., Jonsson, B.F., Folke, C., Falkenmark, M., Johannessen, A., 2005. Human modification of global water vapor flows from the land surface. Proc. Natl. Acad. Sci. 102, 7612-7617. doi:10.1073/pnas.0500208102 
20. Guerrero, I., Morales, M.B., Oñate, J.J., Geiger, F., Berendse, F., Snoo, G. de, Eggers, S., Pärt, T., Bengtsson, J., Clement, L.W., Weisser, W.W., Olszewski, A., Ceryngier, P., Hawro, V., Liira, J., Aavik, T., Fischer, C., Flohre, A., Thies, C., Tscharntke, T., 2012. Response of ground-nesting farmland birds to agricultural intensification across Europe: Landscape and field level management factors. Biol. Conserv. 152, 74-80. doi:10.1016/j.biocon.2012.04.001

21. Herzig, A., Dymond, J., Ausseil, A.-G., 2016. Exploring limits and trade-offs of irrigation and agricultural intensification in the Ruamahanga catchment, New Zealand. New Zeal. J. Agric. Res. 59, 216-234. doi:10.1080/00288233.2016.1183685

22. Jeliazkov, A., Mimet, A., Chargé, R., Jiguet, F., Devictor, V., Chiron, F., 2016. Impacts of agricultural intensification on bird communities: New insights from a multi-level and multi-facet approach of biodiversity. Agric. Ecosyst. Environ. $216,9-22$. doi:10.1016/j.agee.2015.09.017

23. José-María, L., Armengot, L., Blanco-Moreno, J.M., Bassa, M., Sans, F.X., 2010. Effects of agricultural intensification on plant diversity in Mediterranean dryland cereal fields. J. Appl. Ecol. 47, 832-840. doi:10.1111/j.1365-2664.2010.01822.x

24. Karp, D.S., Rominger, A.J., Zook, J., Ranganathan, J., Ehrlich, P.R., Daily, G.C., 2012. Intensive agriculture erodes B-diversity at large scales. Ecol. Lett. 15, 963-970. doi:10.1111/j.1461-0248.2012.01815.x

25. Kleijn, D., Van Der Voort, L.A.C., 1997. Conservation headlands for rare arable weeds: The effects of fertilizer application and light penetration on plant growth. Biol. Conserv. 81, 57-67. doi:10.1016/S0006-3207(96)00153-X

26. Maron, M., Fitzsimons, J.A., 2007. Agricultural intensification and loss of matrix habitat over 23 years in the West Wimmera, south-eastern Australia. Biol. Conserv. 135, 587-593. doi:10.1016/j.biocon.2006.10.051

27. Meeus, J.H.A., 1993. The transformation of agricultural landscapes in Western Europe. Sci. Total Environ. 129, $171-190$.

28. Pielke, R.A., 2001. Influence of the spatial distribution of vegetation and soils on the prediction of cumulus convective rainfall. Rev. Geophys. 39, 151-177. doi:10.1029/1999RG000072

29. Roubos, C.R., Rodriguez-Saona, C., Isaacs, R., 2014. Mitigating the effects of insecticides on arthropod biological control at field and landscape scales. Biol. Control 75, 28-39. doi:10.1016/j.biocontrol.2014.01.006

30. Stoate, C., Boatman, N.D., Borralho, R.J., Carvalho, C.R., de Snoo, G.R., Eden, P., 2001. Ecological impacts of arable intensification in Europe. J. Environ. Manage. 63, 337-365. doi:10.1006/jema.2001.0473

31. Storkey, J., Meyer, S., Still, K.S., Leuschner, C., 2012. The impact of agricultural intensification and land-use change on the European arable flora. Proc. R. Soc. B Biol. Sci. 279, 1421-1429. doi:10.1098/rspb.2011.1686

32. Tilman, D., Fargione, J., Wolff, B., D'Antonio, C., Dobson, A., Howarth, R., Schindler, D., Schlesinger, W.H., Simberloff, D., Swackhamer, D., 2001. Forecasting agriculturally driven global environmental change. Science (80-. ). 292, $281-284$. doi:10.1126/science. 1057544

33. Tscharntke, T., Klein, A.M., Kruess, A., Steffan-Dewenter, I., Thies, C., 2005. Landscape perspectives on agricultural intensification and biodiversity - Ecosystem service management. Ecol. Lett. 8, 857-874. doi:10.1111/j.1461-0248.2005.00782.x

34. Van Oost, K., Govers, G., Desmet, P., 2000. Evaluating the effects of changes in landscape structure on soil erosion by water and tillage. Landsc. Ecol. 15, 577-589. doi:10.1023/A:1008198215674

35. Welch, K.D., Harwood, J.D., 2014. Temporal dynamics of natural enemy-pest interactions in a changing environment. Biol. Control 75, 18-27. doi:10.1016/j.biocontrol.2014.01.004

36. Williams, P.H., 1982. The distribution and decline of British bumble bees (Bombus Latr.). J. Apic. Res. 21, $236-245$. doi:10.1080/00218839.1982.11100549

37. Wilson, J.D., Evans, J., Browne, S.J., King, J.R., 1997. Territory Distribution and Breeding Success of Skylarks Alauda arvensis on Organic and Intensive Farmland in Southern England. J. Appl. Ecol. 34, 1462-1478. 
$1 \quad$ Table S1: Examples of data sources and indicators used by various authors to investigate agricultural intensity.

\begin{tabular}{|c|c|c|}
\hline Study Area & Data sources & Indicator(s) \\
\hline $\begin{array}{l}\text { Beijing mountainous region } \\
\quad \text { (Zhang and } L i, 2016)\end{array}$ & - Statistical Yearbook 2013 & - Emergy analysis of agricultural inputs \\
\hline $\begin{array}{l}\text { Northern Spain } \\
\quad \text { (Armengot et al., 2011) }\end{array}$ & - Interviews & $\begin{array}{l}\text { - Mean annual inputs of exogenous nitrogen } \bullet \text { Weed control } \\
\text { intensity } \bullet \text { Cereal ratio } \bullet \text { Crop diversity } \bullet \text { Seed origin }\end{array}$ \\
\hline $\begin{array}{l}\text { Germany } \\
\quad \text { (Egorov et al., 2014) }\end{array}$ & - Yearly interviews with farmers and land-owners & $\begin{array}{l}\text { - Land Use Intensity Index (LUI): summation of fertilization } \\
\text { level, mowing frequency and grazing intensity }\end{array}$ \\
\hline $\begin{array}{l}\text { France } \\
\text { (Teillard et al., 2012) }\end{array}$ & $\begin{array}{l}\text { - French FADN (Farm Accountancy Data Network) • Datasets from agricultural social } \\
\text { security, CAP declarations, national bovine identification } \bullet \text { Topo-climatic data }\end{array}$ & - Input cost/ha \\
\hline $\begin{array}{l}\text { India } \\
\qquad \text { (Biradar and Xiao, 2011) }\end{array}$ & $\begin{array}{l}- \text { MODIS (EVI, NDVI, LSWI) • Government agricultural census data } \bullet \text { Field ground- } \\
\text { truth data inc. crop types and cropping pattern }\end{array}$ & - Cropping intensity \\
\hline $\begin{array}{l}\text { India } \\
\qquad \text { (Jain et al., 2013) }\end{array}$ & $\begin{array}{l}\text { - Landsat } 5 \text { TM \& Landsat } 7 \text { ETM+ • MODIS (EVI) • Ground-truth data: Landsat, } \\
\text { Quickbird, Worldview \& Google Earth Imagery }\end{array}$ & - Cropping intensity $\bullet$ Multi-cropping \\
\hline $\begin{array}{l}\text { India } \\
\qquad \text { (Singh et al., 2002) }\end{array}$ & - Crop cutting experiments • Crop yield estimation surveys • IRS-1B LISS-II & - Crop yield \\
\hline $\begin{array}{l}\text { Northern China } \\
\quad \text { (Mingwei et al., 2008) }\end{array}$ & - MODIS (NDVI) & - Crop acreage \\
\hline $\begin{array}{l}\text { China } \\
\text { (Yan et al., 2014) }\end{array}$ & $\begin{array}{l}\text { - Agricultural meteorological stations - crop calendar/crop phenological data } \\
\text { •MODIS (EVI) • National LU/LC dataset }\end{array}$ & - Multi-cropping \\
\hline $\begin{array}{l}\text { China } \\
\text { (L. Li et al., 2014) }\end{array}$ & - MODIS (EVI) • National survey data & - Cropping intensity \\
\hline $\begin{array}{l}\text { China } \\
\text { (Xie et al., 2014) }\end{array}$ & - Secondary agricultural statistics e.g. China Rural Statistical Yearbook & - Emergy analysis of inputs to arable land per ha \\
\hline $\begin{array}{l}\text { United States } \\
\qquad \text { (Johnson, 2013) }\end{array}$ & $\begin{array}{l}\text { - Cropland Data Layer LC classifications (derived from Landsat TM by Agricultural } \\
\text { Statistics Service) } \bullet \text { NASS Census of Agriculture \& June Acreage Survey }\end{array}$ & - Area of annually tilled cropland \\
\hline $\begin{array}{l}\text { US Central Great Plains } \\
\text { (Wardlow and Egbert, 2008) }\end{array}$ & - MODIS (NDVI) & - Cropping area \\
\hline $\begin{array}{l}\text { Canada } \\
\qquad \text { (Kerr and Cihlar, 2003) }\end{array}$ & - Canadian Census of Agriculture • SPOT 4 VEG & - Agricultural pollution \\
\hline
\end{tabular}




\section{Study area}

Belgium, France, the

Netherlands and Switzerland

(Le Féon et al., 2010)

\section{Europe}

(Donald et al., 2001)

Europe

$$
\text { (Herzog et al., 2006) }
$$

European Union

$$
\text { (Reidsma et al., 2006) }
$$

European Union

$$
\text { (Temme and Verburg, 2011) }
$$

Europe \& Turkey (Estel et al., 2016)

Russia (de Beurs and loffe, 2014)

Asia

$$
\text { (Gray et al., 2014) }
$$

World

(Johnston et al., 2011)

World

$$
\text { (Niedertscheider et al., 2016) }
$$

World

$$
\text { (Potter et al., 2010) }
$$

World

$$
\text { (Siebert et al., 2010) }
$$

World

$$
\text { (Thenkabail et al., 2009) }
$$

Data sources

- Standardised interviews with farmers

\section{-FAOSTAT database}

- Interviews • Geo-referenced aerial photographs • European Fourier-Adjusted \& Interpolated NDVI dataset (Stockli \& Vidale, 2004)

- FADN survey

- Agricultural statistics \& census data • CORINE land cover map • Land Use/Cover Area frame statistical Survey (LUCAS) dataset

- MODIS NDVI (Terra \& Aqua satellites) • GlobCorine LC Map • Annual fallow/active crop maps

-Landsat $5 \bullet$ MODIS • All-Russia Agricultural Census • Field Observations

- MODIS (EVI)

- Global census data from FAOSTAT database - M3 cropland datasets

- Earthstat gridded maps of crop yields \& crop area

- National level fertiliser data - based on questionnaires $\bullet$ Global maps of harvested Area (from Monfreda et al. 2008) • FAO Gridded Livestock of the World maps

- MIRCA2000 dataset - monthly growing areas of 26 irrigated \& rain-fed crop classes

- AVHRR • SPOT • JERS-1 • CRU rainfall time series (1961-2000) • Global Elevation dataset $\bullet$ Global Tree Cover data $\bullet$ Google Earth $\bullet$ Groundtruth data
Indicator(s)

- Global Intensity Index: based on nitrogen input, livestock density and pesticide input

- PCA analysis based on political \& economic differences

- Nitrogen output $\bullet$ Density of livestock units $\bullet$ Number of pesticide applications

- Input costs • Irrigation use • Organic or not?

- Total nitrogen input

- Cropping frequency $\bullet$ Multi-cropping $\bullet$ Fallow cycles Crop duration ratio

- Cropping intensity

- Multi-cropping

- Yield gap analysis

- Human appropriation of net primary productivity (HANPP)

- Fertiliser inputs of N \& P

- Cropping intensity $\bullet$ Crop duration ratio $\bullet$ Extent of fallow land

- Irrigated area 


\begin{tabular}{|c|c|}
\hline Indicator & Example Methods \\
\hline Crop yield & $\begin{array}{l}\text { NB: A brief review of crop yield estimation techniques can be found in the introduction to } \\
\text { Doraiswamy et al. (2005, 2004, 2003) and Kasampalis et al. (2018) provide an overview of crop } \\
\text { growth models. } \\
\text { - Empirical regression-based modelling linking satellite-derived data (e.g. NDVI) to detailed official } \\
\text { crop statistics (Becker-Reshef et al., 2010; Lobell et al., 2013; Salazar et al., 2007) or ground } \\
\text { survey data (Ferencz et al., 2004; Ren et al., 2008; Yang et al., 2006); supplementary data may } \\
\text { be included as additional explanatory variables (Balaghi et al., 2008; Prasad et al., 2006) } \\
\text { - Estimate yield using regression models based on seasonal growth profiles from satellite-derived } \\
\text { VIs (Kalubarme et al., 2003; Lai et al., 2018; Nagy et al., 2018; Son et al., 2014) } \\
\text { - Crop yield simulation models incorporating satellite-derived data as either direct inputs or for } \\
\text { calibration (Doraiswamy et al., 2005; Lobell et al., 2013; Moriondo et al., 2007) } \\
\text { - Derive crop biomass using the Monteith light use efficiency approach (Awad, 2019; Leblon et al., } \\
\text { 1991; Liu et al., 2010; Monteith, 1972; Morel et al., 2014; Pan et al., 2009; Patel et al., 2006) }\end{array}$ \\
\hline Cropping area & $\begin{array}{l}\text { NB: Gallego (2004) provides a review of some common EO-based land cover area estimation } \\
\text { techniques. } \\
\text { - Pixel counting \& sub-pixel analysis (spectral unmixing, linear mixing models, mixture modelling) } \\
\text { applied to classified satellite images; ground data used as an auxiliary/validation tool (Gallego, } \\
\text { 2004; Gallego et al., 2014; Gumma et al., 2014; Vibhute and Gawali, 2013) } \\
\text { - Regression analysis combining satellite-derived information with an accurate sample (e.g. ground } \\
\text { survey data) (Gallego, 2004; Gallego et al., 2014; Vibhute and Gawali, 2013) } \\
\text { - Derive a cropland probability layer using a combination of classified images and satellite-derived } \\
\text { land surface phenology metrics (de Beurs and loffe, 2014) } \\
\text { - SAR time-series decomposition (Canisius et al., 2018; Ponnurangam and Rao, 2018; Xu et al., } \\
\text { 2019); SAR data may be integrated with multispectral data to assist crop classification (Gao et } \\
\text { al., 2018; Shuai et al., 2019) }\end{array}$ \\
\hline
\end{tabular}

Cropping intensity number of years a field is sown with crops and actually reaches harvest (de Beurs and loffe, 2014)

Cropping frequency - number of years a pixel was cropped over an observation period (Estel et al., 2016)

Multi-cropping -
number of harvests
within a single year
(i.e. growing season)
(Estel et al., 2016)
Cropping intensity -
number of cropping
cycles per year (L. Li
et al., 2014)

Crop duration ratio
Jain et al. (2013) provide a comparison of different methods to map cropping intensity. Methods included are:

- NDVI threshold method - define threshold for cropped land for a particular season based on satellite-derived NDVI, training data and regression tree analysis; use to classify pixels as cropped or uncropped agriculture for all seasons of interest

- EVI peak method: (1) define threshold based on satellite-derived EVI and training data for cropped and non-cropped areas; (2) identify peaks in EVI time series; if peak exceeds threshold then classify it as cropped agriculture

- Hierarchical training technique (using EVI): (1) define the percent of each pixel cropped using higher resolution ground-truth imagery; (2) use this to calibrate EVI to quantify the percent of each pixel that was cropped in each season

- Apply a series of simple decision rules to satellite-derived phenology metrics (phenology model) to distinguish cropped pixels from fallow lands. Example rules in de Beurs \& loffe (2014).

- Use Temporal Mixture Analysis of end-member phenologies to determine whether a pixel is single, double or triple cropped (Jain et al., 2013)

- Use a satellite-based phenology algorithm (e.g. Biradar and Xiao, 2011) to delineate the number of cropping cycles in a year

- Apply time-series segmentation/iterative moving-window methodology to (smoothed) EVI time series to identify greening and browning phases and therefore cropping cycles; use to determine number of cropping cycles per year (Gray et al., 2014)

- Use TIMESAT computer software to count the number of vegetation peaks in NDVI per growing season (Jönsson and Eklundh, 2004 in L. Li et al., 2014; Z. Li et al., 2014)

- Determine the number of growth cycles in a year by counting the number of peaks (using thresholding techniques) on a crop growth curve based on satellite derived VI (e.g. EVI) (Yan et al., 2014)

Ratio of the time period (during the growing season) for which a pixel was cropped and the total length of the growing season (Estel et al., 2016) 

2015); (2) Filter time series for 'chain segments' i.e. certain number of consecutive fallow years; fallow cropland (3) count chain occurrence per pixel across entire time series; (4) summarise all chain segments using a weighting scheme (see Estel et al., 2016 for details).

Table S3: Example EO-based methods used by researchers to assess vegetation health.

\begin{tabular}{|c|c|}
\hline Indicator & Example EO-based Methods \\
\hline \multirow[t]{2}{*}{ Crop condition } & $\begin{array}{l}\text { NB: A review of remote sensing methods for assessing crop condition can be found in Vibhute and } \\
\text { Gawali (2013). }\end{array}$ \\
\hline & $\begin{array}{l}\text { - Vegetation indices e.g. NDVI, NDWI, SAVI etc. - assume the higher the indices, the better the crop } \\
\text { condition (Ali and Pelkey, 2013; Vibhute and Gawali, 2013) } \\
\text { - Same-period comparing - compare EO-derived data (e.g. NDVI, LAI, VCI) of a specific period with } \\
\text { data from period in history to determine areas of deterioration, no-change \& improvement } \\
\text { (Vibhute and Gawali, 2013; Wu et al., 2015, 2014; Zhang et al., 2014) } \\
\text { - Crop growth profile monitoring (Jiang et al., 2003; Vibhute and Gawali, 2013; Wu et al., 2015, } \\
\text { 2014; Zhang et al., 2014) }\end{array}$ \\
\hline
\end{tabular}

\begin{tabular}{|c|c|}
\hline Plant Trait Mapping & $\begin{array}{l}\text { NB: Homolova et al. (2013) and Andrew et al. (2014) provide reviews of remote sensing techniques } \\
\text { for mapping various plant traits. }\end{array}$ \\
\hline $\begin{array}{l}\text { Biophysical traits inc. } \\
\text { biomass, } \\
\text { fAPAR, } \\
\text { photosynthetic } \\
\text { capacity }\end{array}$ & $\begin{array}{l}\text { - Empirical models (e.g. simple linear regression) relating limited field trait observations to EO- } \\
\text { derived data such as vegetation indices (e.g. NDVI, EVI) \& classified images (Baret and Guyot, } \\
\text { 1991; Chen et al., 2010; Homolová et al., 2013; Jackson et al., 2004; Karnieli et al., 2013; } \\
\text { Sakowska et al., 2016; Schino et al., 2003; Sibanda et al., 2015; Turner et al., 1999) } \\
\text { - Radiative Transfer Models (RTM) (Homolová et al., 2013; Myneni et al., 1997) } \\
\text { - Estimate fAPAR using Neural Networks (Baghdadi et al., 2016) } \\
\text { - Hyperspectral methods such as partial least squares regression (Hansen and Schjoerring, 2003) }\end{array}$ \\
\hline $\begin{array}{l}\text { Structural traits inc. } \\
\text { crop/canopy height, } \\
\text { leaf area index (LAI), } \\
\text { biomass, canopy } \\
\text { morphology }\end{array}$ & $\begin{array}{l}\text { NB: The introduction to Atzberger (2010) provides a brief overview of methods used to estimate LAI. } \\
\text { - Empirical models using spectral data, VIs or image texture metrics (Andrew et al., 2014; Baret and } \\
\text { Guyot, 1991; Clevers et al., 2017; Delegido et al., 2011; Z. Li et al., 2014; Wulder et al., 2004) } \\
\text { - RTM-based approaches e.g. SAIL (Atzberger, 2010; Doraiswamy et al., 2004; Frampton et al., 2013; } \\
\text { Homolová et al., 2013; Jackson et al., 2004; Myneni et al., 1997; Verhoef, 1984) } \\
\text { - Estimate using correlation between surface properties and backscatter from active sensors } \\
\text { (Andrew et al., 2014; Z. Li et al., 2014) e.g. LiDAR (Drake et al., 2002; van Leeuwen and } \\
\text { Nieuwenhuis, 2010) \& Radar (Brisco and Brown, 1998; Kasischke et al., 1997) }\end{array}$ \\
\hline
\end{tabular}

\section{Biochemical traits} inc. chlorophyll (Ch) \& water content, nitrogen $(N)$ \& phosphorous $(P)$ status
- Empirical methods using vegetation indices (VIs) (Andrew et al., 2014; Khanna et al., 2007; Sakowska et al., 2016) for example: Double-peak Canopy Nitrogen Index (DCNI) (Chen et al., 2010); Modified triangle vegetation index 2 (Bagheri et al., 2013); NDVI (Cheng et al., 2008); Narrowband Green NDVI (NGNDVI) (Bausch and Khosla, 2010); Normalised Difference Water Index (NDWI) (Gao, 1996); Short-wave Infrared Water Stress Index (SIWSI) (Briant et al., 2010; Fensholt and Sandholt, 2003); Triangular Greenness Index (TGI) (Hunt et al., 2013); MERIS Terrestrial Chlorophyll Index (MTCI) (Dash and Curran, 2007)

- RTM inversion e.g. REGFLEC (Andrew et al., 2014; Boegh et al., 2013; Frampton et al., 2013; Homolová et al., 2013; Houborg and Boegh, 2008; Jackson et al., 2004; Trombetti et al., 2008)

- Estimate chlorophyll content using the red edge position (REP) (Z. Li et al., 2014) 
Table S4: Example EO-based methods used by researchers to assess soil quality and soil erosion/protection.

\begin{tabular}{|c|c|}
\hline Indicator & Example EO-based Methods \\
\hline Soil Quality & NB: Shoshany et al. (2013) provide a review of EO methods for monitoring agricultural soil degradation \\
\hline $\begin{array}{l}\text { Soil carbon }(C) \& \\
\text { oraanic matter }\end{array}$ & - Empirical modelling (e.g. partial least squares regression, random forest) (Andrew et al., 2014; Castaldi et \\
\hline$(O M)$ & $\begin{array}{l}\text { - Quantify using particular absorption features in the VIS-NIR-SWIR region (Ben Dor et al., } 1999 \text { in } \\
\text { Shoshany et al., 2013) or the degree of concavity of the reflectance spectrum in VIS wavelengths } \\
\text { (Andrew et al., 2014; Palacios-Orueta and Ustin, 1998) }\end{array}$ \\
\hline
\end{tabular}

Crop residue/ conservation tillage density

- Map organic residue (or non-photosynthetic vegetation) cover using spectral unmixing approaches (Andrew et al., 2014; Pacheco and McNairn, 2010)

- Spectral indices designed for detecting crop residues include: Normalised Difference Tillage Index (NDTI) and Normalised Difference Senescent Vegetation Index (NDSVI) (Daughtry et al., 2006, 2005)

- Map crop residue using a multiband reflectance algorithm e.g. Crop Residue Index Multiband (CRIM) (Biard and Baret, 1997)

Nitrogen $(N) \quad-$ Assess based on two premises: (1) N mineralisation \& subsequent availability to growing crop will be status) proportional to OM content i.e. darker soil implies high soil nitrate levels (Scharf et al., 2002); (2) N availability Stress increases canopy reflectance over all visible wavelengths (Beatty et al., 2000 in Scharf et al., 2002) - indices combining VIS \& NIR regions may maximise sensitivity to N stress (Eitel et al., 2011; Scharf et al., 2002; Tilling et al., 2007)

- Assess nitrogen status using surface indicators of subsurface nutrient conditions using multispectral and hyperspectral techniques (Shoshany et al., 2013)

Soil salinity NB: A review of the potentials and constraints of remote sensing-based soil salinity mapping can be found in Metternicht \& Zinck (2003).

- Machine learning and regression-based models e.g. Multilayer Perception Neural Networks, Artificial Neural Networks, Gaussian Processes, Partial Least Square Regression, Support Vector Regression and Random Forest (Farifteh et al., 2007; Hoa et al., 2019; Taghadosi et al., 2019)

- Categorical mapping of regions of differing soil salinity (e.g. high, medium, low) using hyperspectral satellite data and image classification (e.g. minimum distance, maximum likelihood) and spectral unmixing techniques (Ghosh et al., 2012; Hamzeh et al., 2016)

- Quantitative mapping of soil salinity using indices derived from hyperspectral data and regression techniques (e.g. partial least squares regression, linear regression) (Bai et al., 2018; Hamzeh et al., 2013; Kumar et al., 2015; Mashimbye et al., 2012; Qian et al., 2019; Weng et al., 2008)

- Distinguish 'normal' soil from moderately or severely salt-affected soils using brightness approach (Koshal 2010 in Shoshany et al., 2013)

- Use spectral indices including Salinity Index (SI), Normalised Differential Salinity Index (NDSI) \& Brightness Index (BI) (Asfaw et al., 2018; Dehni and Lounis, 2012; Khan et al., 2005; Shoshany et al., 2013)

- Detect salinisation-related surface roughness features (e.g. crusting) using variation in radar backscattering \& InSAR coherence signals (C,P \& R wavelengths) (Metternicht and Zinck, 2003; Shoshany et al., 2013; Taylor et al., 1996)

Soil moisture (SM) NB: Srivastava (2017) provides a review of satellite-based methods for monitoring soil moisture, while content Petropoulos et al. (2018) provide an overview of the state of the art of EO techniques to derive operational estimates of soil moisture.

- Empirical \& semi-empirical models relating backscattering coefficient to soil water content (\& soil surface roughness) (Attarzadeh et al., 2018; Bao et al., 2018; Bousbih et al., 2018; Dubois et al., 1995; Genis et al., 2013; Hajj et al., 2017; Hosseini et al., 2015; Huang et al., 2019; Zhang et al., 2017)

- RTM-based approaches relating soil dielectric constant to soil moisture (Bablet et al., 2018; Dubois et al., 1995; Hosseini et al., 2015; Jackson, 2002; Wagner et al., 2007)

- Spectral indices e.g. Normalised Multiband Drought Index (NMDI) (Shoshany et al., 2013; Wang and Qu, 2009)

- Retrieval from thermal data using apparent thermal inertia (ATI) (Shoshany et al., 2013; Verstraeten et al., 2006; Wang and Qu, 2009)

- Map surface roughness \& SM in sparsely vegetated landscapes using a multi-angle (radar-based) approach \& an Integral Equation Model retrieval algorithm (Rahman et al., 2008)

Soil erosion/ NB: Vrielling (2006) provide a review of satellite-based techniques for assessing erosion
et al., 1995; Dwivedi et al., 1997; Fadul et al., 1999; Metternicht and Zinck, 1998; Wang et al., 2013) 
- Visual interpretation of high resolution images (Dwivedi et al., 1997; Fadul et al., 1999; Wang et al., 2013) detection

- Estimate metric dimensions \& volume of individual patches of sheet, rill \& gully erosion \& densities (Metternicht and Zinck, 1998; Shoshany et al., 2013)

- Potential to use InSAR multi-temporal interferometric coherence change technique (Shoshany et al., 2013)

Erosion modelling • Erosion Potential Index (EPI) (Shoshany et al., 2013)

- Integrate EO-derived data into soil loss/erosion models (Cyr et al., 1995) such as USLE (Universal Soil Loss Equation), ANSWERS (Areal Non-Point Source Watershed Environment Response Simulation), SEMMED (Soil Erosion Model for Mediterranean Regions) (De Jong, 1994; De Jong et al., 1999; Ganasri and Ramesh, 2016; Shoshany et al., 2013). EO derived-data includes: land use/land cover map (Baban and Yusof, 2001; De Jong et al., 1999; Ganasri and Ramesh, 2016; Sharma and Singh, 1995), interception or total vegetation cover (De Jong, 1994), and soil parameter data (Baban and Yusof, 2001; De Jong et al., 1999; Sharma and Singh, 1995)

Table S5: Example EO-based methods used by researchers to assess water quality and water availability.

\begin{tabular}{|c|c|}
\hline Indicator & Example EO-based Methods \\
\hline Water Quality & $\begin{array}{l}\text { NB: Reviews of various EO-based techniques for assessing various water quality parameters } \\
\text { can be found in Gholizadeh et al. (2016a, 2016b); Dornhofer \& Oppelt (2016) and Chang } \\
\text { et al. (2015) }\end{array}$ \\
\hline Water Quality Indices & $\begin{array}{l}\text { - Water Quality indices derived from different combinations of spectral bands (Vignolo et al., } \\
\text { 2006; Wen and Yang, 2010) }\end{array}$ \\
\hline $\begin{array}{l}\text { Physical water quality } \\
\text { parameters: total suspended } \\
\text { solids (TSS), turbidity, } \\
\text { suspended sediment } \\
\text { concentration (SSC), } \\
\text { chlorophyll concentration, } \\
\text { temperature \& water clarity }\end{array}$ & $\begin{array}{l}\text { - Empirical (simple or multiple regression) modelling - relate field data (or water quality } \\
\text { indices derived from field data) to satellite data (e.g. band ratios) to estimate water } \\
\text { quality parameters (Blix et al., 2018; Carpenter and Carpenter, 1983; Chen et al., 2007; } \\
\text { Ha et al., 2017; Hu et al., 2004; Kloiber et al., 2002; Lavery et al., 1993; Liu et al., 2017; } \\
\text { Pereira-Sandoval et al., 2018; Ritchie and Cooper, 2001; Sòria-perpinyà et al., 2019) } \\
\text { - Spectral unmixing-based approach - end-member spectra related to physical water quality } \\
\text { parameters such as SSC (Martinez et al., 2008) }\end{array}$ \\
\hline $\begin{array}{l}\text { Chemical water quality } \\
\text { parameters: concentration } \\
\text { of total nitrogen (TN), } \mathrm{NO}_{3}-\mathrm{N} \\
\text { (nitrate as nitrogen) \& total } \\
\text { phosphorous (TP) }\end{array}$ & $\begin{array}{l}\text { - Empirical (regression) modelling - relate field data to satellite data to estimate water } \\
\text { quality parameters (Chen and Quan, 2012; Wu et al., 2010) } \\
\text { - Use neural network modelling (e.g. back-propagation neural network model) to establish a } \\
\text { retrieval model for concentrations of TN \& TP on the basis of satellite data (Xiao et al., } \\
\text { 2015) }\end{array}$ \\
\hline Water quality proxy & $\begin{array}{l}\text { - Assess health of vegetation alongside water bodies as a proxy for water quality, using } \\
\text { vegetation indices (e.g. NDVI, EVI) (Trivero et al., 2013) } \\
\text { - Identification and mapping of submergent aquatic vegetation using image interpretation } \\
\text { and classification techniques (Ackleson and Klemas, 1987; Dogan et al., 2009; Wolter et } \\
\text { al., 2005; Yang, 2005) }\end{array}$ \\
\hline
\end{tabular}

\section{Water Availability}

Water body area \& configuration
- Detect/classify water bodies using optical data (NIR \& SWIR regions) or spectral indices (e.g. NDVI \& NDWI) (Andrew et al., 2014; Frazier and Page, 2000; Mueller et al., 2016; Smith, 1997; Tulbure and Broich, 2013)

- WiPE water body classification algorithm (Ngoc et al., 2019)

- Determine water body area using pixel counting \& vector-based GIS methods (Verpoorter et al., 2012)

- Quantify the spatial configuration of water bodies (e.g. number of water bodies, mean surface water body area) based on classified satellite images using FRAGSTATS software (v4) (McGarigal et al., 2012; Tulbure and Broich, 2013)

NB: Detection of water bodies may be enhanced through use of techniques such as Principal Component Analysis (PCA) (Verpoorter et al., 2012)

Water level \& volume Michailovsky et al., 2012; Smith, 1997; Sulistioadi et al., 2015)

- Use satellite-derived LC data as an input into models to estimate the volume of water yield available for consumptive purposes (Crossman et al., 2013) 
Water use efficiency \& crop water stress
- Use satellite-derived data including VIs, NIR \& TIR data as inputs into evapotranspiration models such as SEBAL (Surface Energy Balance for Land) (Bastiaanssen, 2000; Bastiaanssen et al., 1998; Mutiga et al., 2010), METRIC (Allen et al., 2007) and ALEXI/DisALEXI (Anderson et al., 2011) to predict actual evapotranspiration as an indicator of crop water stress and whether water is being used as intended (GonzalezDugo et al., 2009; Mutiga et al., 2010)

- Use TIR satellite data to calculate Evaporative Stress Index (ESI) to detect drought conditions and to infer crop health (Anderson and Kustas, 2008)

Table S6: Example EO-based methods used by researchers to assess biodiversity.

\begin{tabular}{|c|c|}
\hline Indicator & Example EO-based Methods \\
\hline & $\begin{array}{l}\text { NB: EO-based techniques for monitoring biodiversity have been review by a number of authors including } \\
\text { Gillespie et al. (2008), Kerr and Ostrovsky (2003), Kuenzer et al. (2014), Mairota et al. (2015), Nagendra } \\
\text { (2001), Rocchini et al. (2010), Turner et al. (2003) and Wang et al. (2010) }\end{array}$ \\
\hline $\begin{array}{l}\text { Direct } \\
\text { mapping of } \\
\text { individuals } \\
\text { and } \\
\text { associations }\end{array}$ & $\begin{array}{l}\text { - Map individual plants or associations of single species by applying pixel- or object-based classification } \\
\text { procedures to high spatial resolution data (Ban, 2003; Clark et al., 2001; Crossman et al., 2013; Feng et } \\
\text { al., 2010; Gillespie et al., 2008; Lauver, 1997; Nagendra and Gadgil, 1999; Turner et al., 2003; Vibhute } \\
\text { and Gawali, 2013). Species differentiation aided by differences in size, shape and vertical structure of } \\
\text { canopies in active RS (e.g. LiDAR) or hyperspectral data (Andrew et al., 2014) } \\
\text { - Extract unique multi-temporal signature for different crops from VIs (e.g. NDVI \& EVI) (Wardlow et al., } \\
\text { 2007) } \\
\text { - Harmonic (Fourier) analysis of NDVI time series (Jakubauskas et al., 2002; Mingwei et al., 2008) } \\
\text { - Classify vegetation types using visual and digital interpretation of false colour composites and SAR images } \\
\text { based on derived characteristics including size, shape and texture (Blaes et al., 2005; Ravan et al., 1995) }\end{array}$ \\
\hline
\end{tabular}

Plant (and animal) species diversity
- Assess species diversity and distribution patterns by examining direct relationships between EO-derived spectral radiance values and species distribution patterns recorded from field observations (Feng et al., 2010; Nagendra, 2001)

- Use satellite-based land use and landscape complexity indices (e.g. patch shape indices) to predict regional plant species diversity (Honnay et al., 2003)

- Predict distribution or probability of occurrence of individual species and species assemblages using multiple regression analysis and EO-based data such as land cover maps (Jennings, 2000; Kerr et al., 2001; Kerr and Ostrovsky, 2003; Luoto et al., 2002a; Saveraid et al., 2001); supplementary material such as climate and topography data may be incorporated (Cumming, 2000; Nagendra, 2001)

Habitat - Model distribution and abundance of single species using detailed information about known habitat suitability requirements and EO-derived land cover, habitat maps and landscape metrics (Amici et al., 2010; Feng et al., 2010; Kerr et al., 2001; Kerr and Ostrovsky, 2003; Z. Li et al., 2014; Luoto et al., 2002b; Mairota et al., 2015; Nagendra, 2001; Weiers et al., 2004)

- Habitat suitability parameters include: spectral and textural indexes (Muñoz and Felicísimo, 2004; Stickler and Southworth, 2008); canopy cover (Davis et al., 2007); NPP (Meynard and Quinn, 2007); existence of suitable water bodies (Weiers et al., 2004); and hedgerow networks (Vannier et al., 2011)

Landscape

- Derive quantitative measures of landscape structure (e.g. composition, isolation and complexity) from

structure land cover classifications (Gustafson, 1998; Kuenzer et al., 2014; Luoto et al., 2002a; Rocchini et al., 2010)

- Landscape metrics can be computed by software products including FRAGSTATS (v4) using raster or vector data (McGarigal et al., 2012)

- Landscape diversity may be represented using diversity indices combining richness (number of classes present) and evenness (distribution of area among classes) (Gustafson, 1998). Examples include Shannon's and Simpson's diversity indices (Shannon and Weaver, 1948 and Simpson, 1949 in Gustafson, 1998).

- Use image classification to map landscape connectivity elements (e.g. hedgerows) (Vannier et al., 2011)

-Quantify landscape fragmentation using pattern indices (Saura, 2004) such as number of patches and mean patch size (Turner and Ruscher, 1988 in Saura, 2004) and patch cohesion index (Schumaker, 1996) 
Species $\quad$ Species-Energy Theory - species richness is proportional to NPP, derived from e.g. NDVI (Currie, 1991;

richness Kerr and Ostrovsky, 2003; Z. Li et al., 2014; Nagendra, 2001)

- Spectral Variation Hypothesis - assume higher variation in spectra implies higher habitat heterogeneity, allowing coexistence of more species and consequently higher species richness (Diamond, 1988 in Fairbanks and McGwire, 2004; Z. Li et al., 2014; Palmer et al., 2002; Rocchini et al., 2007)

- Estimate spatial variation in species richness based on NDVI variability, vegetation classification map \& multiple regression analysis (Bawa et al., 2002; Bino et al., 2008; Bonthoux et al., 2018; Carrasco et al., 2018; Fairbanks and McGwire, 2004; Gould, 2000)

Invasive NB: Bradley et al. (2014) provide a review of remote sensing-based techniques for detecting invasive species

species - Identify invasive species using visual interpretation, pixel-based \& object-based classification, \& spectral mixing/unmixing approaches (Huang and Asner, 2009; Z. Li et al., 2014; Walsh et al., 2008)

- Map vegetation species from spectral and textural data using image classification techniques (e.g. maximum likelihood classification) (Kimothi and Dasari, 2010; Laba et al., 2010, 2008; Mirik and Ansley, 2012), neural networks (Fuller, 2005) and principal component analysis (Tsai et al., 2007)

- Texture-augmented image analysis (Tsai and Chou, 2006)

- Maximum Entropy Model (Evangelista et al., 2009)

Table S7: Example EO-based methods used by researchers to assess ecosystem health.

\begin{tabular}{|c|c|c|}
\hline \multicolumn{2}{|l|}{ Indicator } & \multirow{2}{*}{$\begin{array}{l}\text { Example EO-based Methods } \\
\text { NB: EO-based techniques for monitoring ecosystem health have been reviewed by a } \\
\text { number of authors including Andrew et al. (2014), Feng et al. (2010) and Z. Li et al. } \\
\text { (2014) }\end{array}$} \\
\hline & & \\
\hline \multirow[t]{3}{*}{ Vigour } & $\begin{array}{l}\text { Net Primary } \\
\text { Productivity } \\
\text { (NPP) \& Gross } \\
\text { Primary } \\
\text { Productivity } \\
\text { (GPP) }\end{array}$ & $\begin{array}{l}\text { - Model based on Light Use Efficiency (LUE) Concept (Feng et al., 2010; Monteith, } 1972 \\
\text { and Prince } 1991 \text { in Z. Li et al., 2014; Ruimy and Saugier, 1994) } \\
\text { - Statistical empirical model of GPP or NPP \& a vegetation indices such as NDVI or EVI } \\
\text { (Feng et al., 2010; Z. Li et al., 2014; Olofsson et al., 2008; Xu et al., 2012) } \\
\text { - Estimate GPP based on photosynthetic capacity quantified using satellite-based leaf } \\
\text { Ch content estimates e.g. from Clgreen index (Gitelson et al., 2008; Houborg et al., } \\
\text { 2013) }\end{array}$ \\
\hline & $\begin{array}{l}\text { Fractional cover } \\
\text { of green } \\
\text { vegetation, non- } \\
\text { photosynthetic } \\
\text { vegetation } \\
\text { (NPV) \& bare } \\
\text { soil }\end{array}$ & $\begin{array}{l}\text { - Spectral mixing approach (Asner and Heidebrecht, 2002; Gill and Phinn, 2009; } \\
\text { Gitelson, 2013; Z. Li et al., 2014; Pacheco and McNairn, 2010) } \\
\text { - Empirical model of fractional vegetation cover \& vegetation indices (Carlson and } \\
\text { Ripley, 1997; Gitelson, 2013; Guerschman et al., 2009; Z. Li et al., 2014; Wang et al., } \\
\text { 2018) } \\
\text { - Estimate using a neural network based on NIR \& red reflectances (Baret et al., 1995; } \\
\text { Gitelson, 2013) }\end{array}$ \\
\hline & $\begin{array}{l}\text { Biochemical } \\
\text { properties inc. } \\
N, P \& \\
\text { chlorophyll }\end{array}$ & $\begin{array}{l}\text { - Empirical modelling (based on biochemical spectra features) inc. simple linear } \\
\text { regression, partial least-squares regression (PLSR) \& stepwise linear regression } \\
\text { (SMLR) (Homolová et al., 2013; Z. Li et al., 2014) }\end{array}$ \\
\hline \multirow[t]{2}{*}{ Organisation } & $\begin{array}{l}\text { Species richness } \\
\& \text { biodiversity }\end{array}$ & See table S6 \\
\hline & Structural traits & See table S2 \\
\hline Resilience & & $\begin{array}{l}\text { - Assessed based on a ratio of a given ES health indicator, e.g. aboveground biomass, } \\
\text { measured pre- \& post-disturbance (Z. Li et al., 2014) } \\
\text { - Vegetation indices e.g. NDVI time series frequently used to assess/monitor variation } \\
\text { in vegetation health \& deviation from normal conditions over time or in response to } \\
\text { specific disturbances (Z. Li et al., 2014) such as climate change (Li and Guo, 2012), } \\
\text { wildfires (Díaz-Delgado et al., 2002) \& grazing intensity (Numata et al., 2007) }\end{array}$ \\
\hline
\end{tabular}


- Use EO data (e.g. land cover) as an input for Ecosystem Services Models e.g. InVEST, ARIES, SoIVES, GUMBO to assess the ability of an ecosystem to provide various ESS

- Indirect modelling techniques include deriving empirical models of ESS or their providers based on spatial environmental covariates, and using maps of biophysical drivers of ESS supply to parameterise mechanistic models (Andrew et al., 2014).

\section{References for Tables S1-S7}

Ackleson, S.G., Klemas, V., 1987. Remote sensing of submerged aquatic vegetation in lower chesapeake bay: A comparison of Landsat MSS to TM imagery. Remote Sens. Environ. 22, 235-248. doi:10.1016/0034-4257(87)90060-5

Ali, R., Pelkey, N., 2013. Satellite images indicate vegetation degradation due to invasive herbivores in the Andaman Islands. Curr. Sci. 105, 209-214.

Allen, R.G., Tasumi, M., Morse, A., Trezza, R., Wright, J.L., Bastiaanssen, W., Kramber, W., Lorite, I., Robison, C.W., 2007. Satellite-Based Energy Balance for Mapping Evapotranspiration with Internalized Calibration (METRIC) -Applications. J. Irrig. Drain. Eng. 133, 395-406. doi:10.1061/(ASCE)0733-9437(2007)133:4(395)

Amici, V., Geri, F., Battisti, C., 2010. An integrated method to create habitat suitability models for fragmented landscapes. J. Nat. Conserv. 18, 215-223. doi:10.1016/j.jnc.2009.10.002

Anderson, M., Kustas, W., 2008. Thermal remote sensing of drought and evapotranspiration. Eos (Washington. DC). 89, 233240. doi:10.1029/2008EO260001

Anderson, M.C., Kustas, W.P., Norman, J.M., Hain, C.R., Mecikalski, J.R., Schultz, L., González-Dugo, M.P., Cammalleri, C., D’Urso, G., Pimstein, A., Gao, F., 2011. Mapping daily evapotranspiration at field to continental scales using geostationary and polar orbiting satellite imagery. Hydrol. Earth Syst. Sci. 15, 223-239. doi:10.5194/hess-15-223-2011

Andrew, M.E., Wulder, M.A., Nelson, T.A., 2014. Potential contributions of remote sensing to ecosystem service assessments. Prog. Phys. Geogr. 38, 1-26. doi:10.1177/0309133314528942

Armengot, L., José-María, L., Blanco-Moreno, J.M., Bassa, M., Chamorro, L., Xavier Sans, F., 2011. A novel index of land use intensity for organic and conventional farming of Mediterranean cereal fields. Agron. Sustain. Dev. 31, 699-707. doi:10.1007/s13593-011-0042-0

Asfaw, E., Suryabhagavan, K. V., Argaw, M., 2018. Soil salinity modeling and mapping using remote sensing and GIS: The case of Wonji sugar cane irrigation farm, Ethiopia. J. Saudi Soc. Agric. Sci. 17, 250-258. doi:10.1016/j.jssas.2016.05.003

Asner, G.P., Heidebrecht, K.B., 2002. Spectral unmixing of vegetation, soil and dry carbon cover in arid regions: comparing multispectral and hyperspectral observations. Int. J. Remote Sens. 23, 3939-3958. doi:10.1080/01431160110115960

Attarzadeh, R., Amini, J., Notarnicola, C., Greifeneder, F., 2018. Synergetic Use of Sentinel-1 and Sentinel-2 Data for Soil Moisture Mapping at Plot Scale. Remote Sens. 10, 1285. doi:10.3390/rs10081285

Atzberger, C., 2010. Inverting the PROSAIL canopy reflectance model using neural nets trained on streamlined databases. J. Spectr. Imaging 1, 1-13. doi:10.1255/jsi.2010.a2

Awad, M., 2019. Toward Precision in Crop Yield Estimation Using Remote Sensing and Optimization Techniques. Agriculture 9, 54. doi:10.3390/agriculture 9030054

Baban, S.M.J., Yusof, K.W., 2001. Modelling soil erosion in tropical environments using remote sensing and geographical information systems. Hydrol. Sci. -Journal-des Sci. Hydrol. 46, 191-198. doi:10.1080/02626660109492815

Bablet, A., Vu, P.V.H., Jacquemoud, S., Viallefont-Robinet, F., Fabre, S., Briottet, X., Sadeghi, M., Whiting, M.L., Baret, F., Tian, J., 2018. MARMIT: A multilayer radiative transfer model of soil reflectance to estimate surface soil moisture content in the solar domain (400-2500 nm). Remote Sens. Environ. 217, 1-17. doi:10.1016/j.rse.2018.07.031

Baghdadi, N., Hajj, M. El, Zribi, M., Fayad, I., 2016. Coupling SAR C-band and optical data for soil moisture and leaf area index retrieval over irrigated grasslands. IEEE J. Sel. Top. Appl. Earth Obs. Remote Sens. 9, 1229-1243. 
doi:10.1109/JSTARS.2015.2464698

Bagheri, N., Ahmadi, H., Kazem Alavipanah, S., Omid, M., 2013. Multispectral remote sensing for site-specific nitrogen fertilizer management. Pesqui. Agropeuária Bras. 48, 1394-1401. doi:10.1590/S0100-204X2013001000011

Bai, L., Wang, C., Zang, S., Wu, C., Luo, J., Wu, Y., 2018. Mapping soil alkalinity and salinity in northern songnen plain, China with the hj-1 hyperspectral imager data and partial least squares regression. Sensors 18, 3855. doi:10.3390/s18113855

Balaghi, R., Tychon, B., Eerens, H., Jlibene, M., 2008. Empirical regression models using NDVI, rainfall and temperature data for the early prediction of wheat grain yields in Morocco. Int. J. Appl. Earth Obs. Geoinf. 10, 438-452. doi:10.1016/j.jag.2006.12.001

Ban, Y., 2003. Synergy of multitemporal ERS-1 SAR and Landsat TM data for classification of agricultural crops. Can. J. Remote Sens. 29, 518-526. doi:10.5589/m03-014

Bao, Y., Lin, L., Wu, S., Kwal Deng, K.A., Petropoulos, G.P., 2018. Surface soil moisture retrievals over partially vegetated areas from the synergy of Sentinel-1 and Landsat 8 data using a modified water-cloud model. Int. J. Appl. Earth Obs. Geoinf. 72, 76-85. doi:10.1016/j.jag.2018.05.026

Baret, F., Clevers, J.G.P.W., Steven, M.D., 1995. The robustness of canopy gap fraction estimates from red and near-infrared reflectances: A comparison of approaches. Remote Sens. Environ. 54, 141-151. doi:10.1016/0034-4257(95)00136-O

Baret, F., Guyot, G., 1991. Potentials and Limits of Vegetation Indices for LAI and APAR Assessment. Remote Sens. Environ. 35, 161-173. doi:10.1016/0034-4257(91)90009-U

Bastiaanssen, W.G.M., 2000. SEBAL-based sensible and latent heat fluxes in the irrigated Gediz Basin, Turkey. J. Hydrol. 229, 87100. doi:10.1016/S0022-1694(99)00202-4

Bastiaanssen, W.G.M., Menenti, M., Feddes, R.A., Holtslag, A.A.M., 1998. A remote sensing surface energy balance algorithm for land (SEBAL) 1. Formulation. J. Hydrol. 212-213, 198-212. doi:10.1016/S0022-1694(98)00253-4

Bausch, W.C., Khosla, R., 2010. QuickBird satellite versus ground-based multi-spectral data for estimating nitrogen status of irrigated maize. Precis. Agric. 11, 274-290. doi:10.1007/s11119-009-9133-1

Bawa, K., Rose, J., Ganeshaiah, K.N., Barve, N., Kiran, M.C., Umashaanker, R., 2002. Assessing biodiversity from space: An example from the Western Ghats, India. Conserv. Ecol. 6, 7. doi:10.5751/ES-00434-060207

Becker-Reshef, I., Vermote, E., Lindeman, M., Justice, C., 2010. A generalized regression-based model for forecasting winter wheat yields in Kansas and Ukraine using MODIS data. Remote Sens. Environ. 114, 1312-1323. doi:10.1016/j.rse.2010.01.010

Biard, F., Baret, F., 1997. Crop Residue Estimation Using Multiband Reflectance. Remote Sens. Environ. 59, 530-536. doi:10.1016/S0034-4257(96)00125-3

Bino, G., Levin, N., Darawshi, S., Van Der Hal, N., Reich-Solomon, a., Kark, S., 2008. Accurate prediction of bird species richness patterns in an urban environment using Landsat-derived NDVI and spectral unmixing. Int. J. Remote Sens. 29, 3675-3700. doi:10.1080/01431160701772534

Biradar, C.M., Xiao, X., 2011. Quantifying the area and spatial distribution of double-and triple-cropping croplands in India with multi-temporal MODIS imagery in 2005. Int. J. Remote Sens. 32, 367-386. doi:10.1080/01431160903464179

Blaes, X., Vanhalle, L., Defourny, P., 2005. Efficiency of crop identification based on optical and SAR image time series. Remote Sens. Environ. 96, 352-365. doi:10.1016/j.rse.2005.03.010

Blix, K., Pálffy, K., Tóth, V.R., Eltoft, T., 2018. Remote sensing of water quality parameters over Lake Balaton by using Sentinel-3 OLCl. Water 10, 1428. doi:10.3390/w10101428

Boegh, E., Houborg, R., Bienkowski, J., Braban, C.F., Dalgaard, T., Van Dijk, N., Dragosits, U., Holmes, E., Magliulo, V., Schelde, K., Di Tommasi, P., Vitale, L., Theobald, M.R., Cellier, P., Sutton, M.A., 2013. Remote sensing of LAI, chlorophyll and leaf nitrogen pools of crop- and grasslands in five European landscapes. Biogeosciences 10, 6279-6307. doi:10.5194/bg-10$6279-2013$

Bonthoux, S., Lefèvre, S., Herrault, P.-A., Sheeren, D., 2018. Spatial and Temporal Dependency of NDVI Satellite Imagery in Predicting Bird Diversity over France. Remote Sens. 10, 1136. doi:10.3390/rs10071136 
Bousbih, S., Zribi, M., Hajj, M. El, Baghdadi, N., Lili-Chabaane, Z., Gao, Q., Fanise, P., 2018. Soil moisture and irrigation mapping in a semi-arid region, based on the synergetic use of Sentinel-1 and Sentinel-2 data. Remote Sens. 10, 1953. doi:10.3390/rs10121953

Bradley, B.A., 2014. Remote detection of invasive plants: A review of spectral, textural and phenological approaches. Biol. Invasions 16, 1411-1425. doi:10.1007/s10530-013-0578-9

Briant, G., Gond, V., Laurance, S.G.W., 2010. Habitat fragmentation and the desiccation of forest canopies: A case study from eastern Amazonia. Biol. Conserv. 143, 2763-2769. doi:10.1016/j.biocon.2010.07.024

Brisco, B., Brown, R.J., 1998. Agricultural Applications with Radar, in: Henderson, F.M., Lewis, A.J. (Eds.), Principles and Applications of Imaging Radar - Manual of Remote Sensing Third Edition, Volume 2. John Wiley \& Sons, New York, pp. 381406.

Canisius, F., Shang, J., Liu, J., Huang, X., Ma, B., Jiao, X., Geng, X., Kovacs, J.M., Walters, D., 2018. Tracking crop phenological development using multi-temporal polarimetric Radarsat-2 data. Remote Sens. Environ. 210, 508-518. doi:10.1016/j.rse.2017.07.031

Carlson, T.N., Ripley, D.A., 1997. On the relation between NDVI, fractional vegetation cover, and leaf area index. Remote Sens. Environ. 62, 241-252. doi:10.1016/S0034-4257(97)00104-1

Carpenter, D.J., Carpenter, S.M., 1983. Modeling Inland Water Quality Using Landsat Data. Remote Sens. Environ. 13, $345-352$. doi:10.1016/0034-4257(83)90035-4

Carrasco, L., Norton, L., Henrys, P., Siriwardena, G.M., Rhodes, C.J., Rowland, C., Morton, D., 2018. Habitat diversity and structure regulate British bird richness: Implications of non-linear relationships for conservation. Biol. Conserv. 226, 256263. doi:10.1016/j.biocon.2018.08.010

Castaldi, F., Hueni, A., Chabrillat, S., Ward, K., Buttafuoco, G., Bomans, B., Vreys, K., Brell, M., van Wesemael, B., 2019. Evaluating the capability of the Sentinel 2 data for soil organic carbon prediction in croplands. ISPRS J. Photogramm. Remote Sens. 147, 267-282. doi:10.1016/j.isprsjprs.2018.11.026

Castaldi, F., Palombo, A., Santini, F., Pascucci, S., Pignatti, S., Casa, R., 2016. Evaluation of the potential of the current and forthcoming multispectral and hyperspectral imagers to estimate soil texture and organic carbon. Remote Sens. Environ. 179, 54-65. doi:10.1016/j.rse.2016.03.025

Chang, N. Bin, Imen, S., Vannah, B., 2015. Remote sensing for monitoring surface water quality status and ecosystem state in relation to the nutrient cycle: A 40-year perspective. Crit. Rev. Environ. Sci. Technol. 45, 101-166. doi:10.1080/10643389.2013.829981

Chen, J., Quan, W., 2012. Using Landsat/TM imagery to estimate nitrogen and phosphorus concentration in Taihu Lake, China. IEEE J. Sel. Top. Appl. Earth Obs. Remote Sens. 5, 273-280. doi:10.1109/JSTARS.2011.2174339

Chen, P., Haboudane, D., Tremblay, N., Wang, J., Vigneault, P., Li, B., 2010. New spectral indicator assessing the efficiency of crop nitrogen treatment in corn and wheat. Remote Sens. Environ. 114, 1987-1997. doi:10.1016/j.rse.2010.04.006

Chen, Z., Muller-Karger, F.E., Hu, C., 2007. Remote sensing of water clarity in Tampa Bay. Remote Sens. Environ. 109, $249-259$. doi:10.1016/j.rse.2007.01.002

Cheng, Y.B., Ustin, S.L., Riaño, D., Vanderbilt, V.C., 2008. Water content estimation from hyperspectral images and MODIS indexes in Southeastern Arizona. Remote Sens. Environ. 112, 363-374. doi:10.1016/j.rse.2007.01.023

Clark, P.E., Seyfried, M.S., Harris, B., 2001. Intermountain plant community classification using Landsat TM and SPOT HRV data. J. Range Manag. 54, 152-160. doi:10.2307/4003176

Clevers, J.G.P.W., Kooistra, L., van den Brande, M.M.M., 2017. Using Sentinel-2 data for retrieving LAI and leaf and canopy chlorophyll content of a potato crop. Remote Sens. 9, 405. doi:10.3390/rs9050405

Crossman, N.D., Burkhard, B., Nedkov, S., Willemen, L., Petz, K., Palomo, I., Drakou, E.G., Martín-Lopez, B., McPhearson, T., Boyanova, K., Alkemade, R., Egoh, B., Dunbar, M.B., Maes, J., 2013. A blueprint for mapping and modelling ecosystem services. Ecosyst. Serv. 4, 4-14. doi:10.1016/j.ecoser.2013.02.001

Cumming, G.S., 2000. Using habitat models to map diversity: Pan-African species richness of ticks (Acari: Ixodida). J. Biogeogr. 27, 425-440. doi:10.1046/j.1365-2699.2000.00419.x 
Currie, D.J., 1991. Energy and Large-Scale Patterns of Animal-and Plant-Species Richness. Am. Nat. 137, $27-49$. doi:10.1086/285144

Cyr, L., Bonn, F., Pesant, A., 1995. Vegetation indices derived from remote sensing for an estimation of soil protection against water erosion. Ecol. Modell. 79, 277-285. doi:10.1016/0304-3800(94)00182-H

Dash, J., Curran, P.J., 2007. Evaluation of the MERIS terrestrial chlorophyll index (MTCI). Adv. Sp. Res. 39, $100-104$. doi:10.1016/j.asr.2006.02.034

Daughtry, C.S.T., Doraiswamy, P.C., Hunt, E.R., Stern, A.J., Mcmurtrey lii, J.E., Prueger, J.H., 2006. Remote sensing of crop residue cover and soil tillage intensity. Soil Tillage Res. 91, 101-108. doi:10.1016/j.still.2005.11.013

Daughtry, C.S.T., Hunt, E.R., Doraiswamy, P.C., McMurtrey, J.E., 2005. Remote sensing the spatial distribution of crop residues. Agron. J. 97, 864-871. doi:10.2134/agronj2003.0291

Davis, F.W., Seo, C., Zielinski, W.J., 2007. Regional variation in home-range-scale habitat models for fisher (Martes pennanti) in California. Ecol. Appl. 17, 2195-2213. doi:10.1890/06-1484.1

de Beurs, K.M., loffe, G., 2014. Use of Landsat and MODIS data to remotely estimate Russia's sown area. J. Land Use Sci. 9, 377401. doi:10.1080/1747423X.2013.798038

De Jong, S.M., 1994. Derivation of vegetative variables from a landsat TM image for modelling soil erosion. Earth Surf. Process. Landforms 19, 165-178. doi:10.1002/esp.3290190207

De Jong, S.M., Paracchini, M.L., Bertolo, F., Folving, S., Megier, J., De Roo, A.P.J., 1999. Regional assessment of soil erosion using the distributed model SEMMED and remotely sensed data. Catena 37, 291-308. doi:10.1016/S0341-8162(99)00038-7

Dehni, A., Lounis, M., 2012. Remote sensing techniques for salt affected soil mapping: Application to the Oran region of Algeria. Procedia Eng. 33, 188-198. doi:10.1016/j.proeng.2012.01.1193

Delegido, J., Verrelst, J., Alonso, L., Moreno, J., 2011. Evaluation of sentinel-2 red-edge bands for empirical estimation of green LAl and chlorophyll content. Sensors 11, 7063-7081. doi:10.3390/s110707063

Díaz-Delgado, R., Lloret, F., Pons, X., Terradas, J., 2002. Satellite evidence of decreasing resilience in Mediterranean plant communities after recurrent wildfires. Ecology 83, 2293-2303. doi:10.1890/0012-9658(2002)083[2293:SEODRI]2.0.CO;2

Dogan, O.K., Akyurek, Z., Beklioglu, M., 2009. Identification and mapping of submerged plants in a shallow lake using quickbird satellite data. J. Environ. Manage. 90, 2138-2143. doi:10.1016/j.jenvman.2007.06.022

Donald, P.F., Green, R.E., Heath, M.F., 2001. Agricultural intensification and the collapse of Europe's farmland bird populations. Proc. R. Soc. B 268, 25-29. doi:10.1098/rspb.2000.1325

Doraiswamy, P.C., Hatfield, J.L., Jackson, T.J., Akhmedov, B., Prueger, J., Stern, A., 2004. Crop condition and yield simulations using Landsat and MODIS. Remote Sens. Environ. 92, 548-559. doi:10.1016/j.rse.2004.05.017

Doraiswamy, P.C., Moulin, S., Cook, P.W., Stern, A., 2003. Crop Yield Assessment from Remote Sensing. Photogramm. Eng. Remote Sens. 69, 665-674. doi:10.14358/pers.69.6.665

Doraiswamy, P.C., Sinclair, T.R., Hollinger, S., Akhmedov, B., Stern, A., Prueger, J., 2005. Application of MODIS derived parameters for regional crop yield assessment. Remote Sens. Environ. 97, 192-202. doi:10.1016/j.rse.2005.03.015

Dörnhöfer, K., Oppelt, N., 2016. Remote sensing for lake research and monitoring - Recent advances. Ecol. Indic. 64, $105-122$. doi:10.1016/j.ecolind.2015.12.009

Drake, J.B., Dubayah, R.O., Clark, D.B., Knox, R.G., Blair, J.B., Hofton, M.A., Chazdon, R.L., Weishampel, J.F., Prince, S., 2002. Estimation of tropical forest structural characteristics, using large-footprint lidar. Remote Sens. Environ. 79, 305-319. doi:10.1016/S0034-4257(01)00281-4

Dubois, P.C., van Zyl, J., Engman, T., 1995. Measuring Soil Moisture with Imaging Radars. IEEE Trans. Geosci. Remote Sens. 33, 915-926. doi:10.1109/36.406677

Dwivedi, R.S., Sankar, T.R., Venkataratnam, L., Karale, R.L., Gawande, S.P., Rao, K.V.S., Senchaudhary, S., Bhaumik, K.R., Mukharjee, K.K., 1997. The inventory and monitoring of eroded lands using remote sensing data. Int. J. Remote Sens. 18, 107-119. doi:10.1080/014311697219303 
Egorov, E., Prati, D., Durka, W., Michalski, S., Fischer, M., Schmitt, B., Blaser, S., Brändle, M., 2014. Does land-use intensification decrease plant phylogenetic diversity in local grasslands? PLoS One 9, e103252. doi:10.1371/journal.pone.0103252

Eitel, J.U.H., Vierling, L.A., Litvak, M.E., Long, D.S., Schulthess, U., Ager, A.A., Krofcheck, D.J., Stoscheck, L., 2011. Broadband, rededge information from satellites improves early stress detection in a New Mexico conifer woodland. Remote Sens. Environ. 115, 3640-3646. doi:10.1016/j.rse.2011.09.002

Estel, S., Kuemmerle, T., Alcántara, C., Levers, C., Prishchepov, A., Hostert, P., 2015. Mapping farmland abandonment and recultivation across Europe using MODIS NDVI time series. Remote Sens. Environ. 163. doi:10.1016/j.rse.2015.03.028

Estel, S., Kuemmerle, T., Levers, C., Baumann, M., Hostert, P., 2016. Mapping cropland-use intensity across Europe using MODIS NDVI time series. Environ. Res. Lett. 11. doi:10.1088/1748-9326/11/2/024015

Evangelista, P.H., Stohlgren, T.J., Morisette, J.T., Kumar, S., 2009. Mapping invasive tamarisk (Tamarix): A comparison of singlescene and time-series analyses of remotely sensed data. Remote Sens. 1, 519-533. doi:10.3390/rs1030519

Fadul, H.M., Salih, A.A., Ali, I.A., Inanaga, S., 1999. Use of remote sensing to map gully erosion along the Atbara River, Sudan. JAG 1, 314-1999. doi:10.1016/S0303-2434(99)85010-7

Fairbanks, D.H.K., McGwire, K.C., 2004. Patterns of floristic richness in vegetation communities of California: Regional scale analysis with multi-temporal NDVI. Glob. Ecol. Biogeogr. 13, 221-235. doi:10.1111/j.1466-822X.2004.00092.x

Farifteh, J., Van der Meer, F., Atzberger, C., Carranza, E.J.M., 2007. Quantitative analysis of salt-affected soil reflectance spectra: A comparison of two adaptive methods (PLSR and ANN). Remote Sens. Environ. 110, 59-78. doi:10.1016/j.rse.2007.02.005

Feng, X., Fu, B., Yang, X., Lü, Y., 2010. Remote sensing of ecosystem services: An opportunity for spatially explicit assessment. Chinese Geogr. Sci. 20, 522-535. doi:10.1007/s11769-010-0428-y

Fensholt, R., Sandholt, I., 2003. Derivation of a shortwave infrared water stress index from MODIS near- and shortwave infrared data in a semiarid environment. Remote Sens. Environ. 87, 111-121. doi:10.1016/j.rse.2003.07.002

Ferencz, C., Bognár, P., Lichtenberger, J., Hamar, D., Tarcsai, G., Timár, G., Molnár, G., Pásztor, S.Z., Steinbach, P., Székely, B., Ferencz, O.E., Ferencz-Árkos, I., 2004. Crop yield estimation by satellite remote sensing. Int. J. Remote Sens. 25, 41134149. doi:10.1080/01431160410001698870

Frampton, W.J., Dash, J., Watmough, G., Milton, E.J., 2013. Evaluating the capabilities of Sentinel-2 for quantitative estimation of biophysical variables in vegetation. ISPRS J. Photogramm. Remote Sens. 82, 83-92. doi:10.1016/j.isprsjprs.2013.04.007

Frazier, P.S., Page, K.J., 2000. Water body detection and delineating with Landsat TM data. Photogramm. Eng. Remote Sens. 66, 1461-1467.

Fuller, D.O., 2005. Remote detection of invasive Melaleuca trees (Melaleuca quinquenervia) in South Florida with multispectral IKONOS imagery. Int. J. Remote Sens. 26, 1057-1063. doi:10.1080/01430060512331314119

Gallego, F.J., 2004. Remote sensing and land cover area estimation. Int. J. Remote Sens. 25, 3019-3047. doi:10.1080/01431160310001619607

Gallego, F.J., Kussul, N., Skakun, S., Kravchenko, O., Shelestov, A., Kussul, O., 2014. Efficiency assessment of using satellite data for crop area estimation in Ukraine. Int. J. Appl. Earth Obs. Geoinf. 29, 22-30. doi:10.1016/j.jag.2013.12.013

Ganasri, B.P., Ramesh, H., 2016. Assessment of soil erosion by RUSLE model using remote sensing and GIS - A case study of Nethravathi Basin. Geosci. Front. 7, 953-961. doi:10.1016/j.gsf.2015.10.007

Gao, B.C., 1996. NDWI - A normalized difference water index for remote sensing of vegetation liquid water from space. Remote Sens. Environ. 58, 257-266. doi:10.1016/S0034-4257(96)00067-3

Gao, H., Wang, C., Wang, G., Zhu, J., Tang, Y., Shen, P., Zhu, Z., 2018. A crop classification method integrating GF-3 PolSAR and sentinel-2A optical data in the Dongting lake basin. Sensors 18, 3139. doi:10.3390/s18093139

Genis, A., Vulfson, L., Blumberg, D.G., Sprinstin, M., Kotlyar, A., Freilikher, V., Ben-Asher, J., 2013. Retrieving parameters of bare soil surface roughness and soil water content under arid environment from ERS-1, -2 SAR data. Int. J. Remote Sens. 34, 6202-6215. doi:10.1080/01431161.2013.793862

Gholizadeh, A., Žižala, D., Saberioon, M., Borůvka, L., 2018. Soil organic carbon and texture retrieving and mapping using 
proximal, airborne and Sentinel-2 spectral imaging. Remote Sens. Environ. 218, 89-103. doi:10.1016/j.rse.2018.09.015

Gholizadeh, M.H., Melesse, A.M., Reddi, L., 2016a. A comprehensive review on water quality parameters estimation using remote sensing techniques. Sensors 16, 1298. doi:10.3390/s16081298

Gholizadeh, M.H., Melesse, A.M., Reddi, L., 2016b. Spaceborne and airborne sensors in water quality assessment. Int. J. Remote Sens. 37, 3143-3180. doi:10.1080/01431161.2016.1190477

Ghosh, G., Kumar, S., Saha, S.K., 2012. Hyperspectral Satellite Data in Mapping Salt-Affected Soils Using Linear Spectral Unmixing Analysis. J. Indian Soc. Remote Sens. 40, 129-136. doi:10.1007/s12524-011-0143-x

Gill, T.K., Phinn, S.R., 2009. Improvements to ASTER-Derived Fractional Estimates of Bare Ground in a Savanna Rangeland. IEEE Trans. Geosci. Remote Sens. 47, 662-670. doi:10.1109/TGRS.2008.2004628

Gillespie, T.W., Foody, G.M., Rocchini, D., Giorgi, A.P., Saatchi, S., 2008. Measuring and modelling biodiversity from space. Prog. Phys. Geogr. 32, 203-221. doi:10.1177/0309133308093606

Gitelson, A.A., 2013. Remote estimation of crop fractional vegetation cover: the use of noise equivalent as an indicator of performance of vegetation indices. Int. J. Remote Sens. 34, 6054-6066. doi:10.1080/01431161.2013.793868

Gitelson, A.A., Viña, A., Masek, J.G., Verma, S.B., Suyker, A.E., 2008. Synoptic monitoring of gross primary productivity of maize using landsat data. IEEE Geosci. Remote Sens. Lett. 5, 133-137. doi:10.1109/LGRS.2008.915598

Gonzalez-Dugo, M.P., Neale, C.M.U., Mateos, L., Kustas, W.P., Prueger, J.H., Anderson, M.C., Li, F., 2009. A comparison of operational remote sensing-based models for estimating crop evapotranspiration. Agric. For. Meteorol. 149, 1843-1853. doi:10.1016/j.agrformet.2009.06.012

Gould, W., 2000. Remote Sensing of Vegetation, Plant Species Richness, and Regional Biodiversity Hotspots. Ecol. Appl. 10, 1861-1870. doi:10.2307/2641244

Gray, J., Friedl, M., Frolking, S., Ramankutty, N., Nelson, A., Gumma, M.K., 2014. Mapping Asian cropping intensity with MODIS. IEEE J. Sel. Top. Appl. Earth Obs. Remote Sens. 7, 3373-3379. doi:10.1109/JSTARS.2014.2344630

Guerschman, J.P., Hill, M.J., Renzullo, L.J., Barrett, D.J., Marks, A.S., Botha, E.J., 2009. Estimating fractional cover of photosynthetic vegetation, non-photosynthetic vegetation and bare soil in the Australian tropical savanna region upscaling the EO-1 Hyperion and MODIS sensors. Remote Sens. Environ. 113, 928-945. doi:10.1016/j.rse.2009.01.006

Gumma, M.K., Thenkabail, P.S., Maunahan, A., Islam, S., Nelson, A., 2014. Mapping seasonal rice cropland extent and area in the high cropping intensity environment of Bangladesh using MODIS 500m data for the year 2010. ISPRS J. Photogramm. Remote Sens. 91, 98-113. doi:10.1016/j.isprsjprs.2014.02.007

Guo, J., Chang, X., Gao, Y., Sun, J., Hwang, C., 2009. Lake level variations monitored with satellite altimetry waveform retracking. IEEE J. Sel. Top. Appl. Earth Obs. Remote Sens. 2, 80-86. doi:10.1109/JSTARS.2009.2021673

Gustafson, E.J., 1998. Quantifying Landscape Spatial Pattern: What Is the State of the Art? Ecosystems 1, $143-156$. doi:10.1007/s100219900011

Ha, N.T.T., Thao, N.T.P., Koike, K., Nhuan, M.T., 2017. Selecting the Best Band Ratio to Estimate Chlorophyll-a Concentration in a Tropical Freshwater Lake Using Sentinel 2A Images from a Case Study of Lake Ba Be (Northern Vietnam). ISPRS Int. J. GeoInformation 6, 290. doi:10.3390/ijgi6090290

Hajj, M. El, Baghdadi, N., Zribi, M., Bazzi, H., 2017. Synergic use of Sentinel-1 and Sentinel-2 images for operational soil moisture mapping at high spatial resolution over agricultural areas. Remote Sens. 9, 1292. doi:10.3390/rs9121292

Hamzeh, S., Naseri, A.A., AlaviPanah, S.K., Bartholomeus, H., Herold, M., 2016. Assessing the accuracy of hyperspectral and multispectral satellite imagery for categorical and quantitative mapping of salinity stress in sugarcane fields. Int. J. Appl. Earth Obs. Geoinf. 52, 412-421. doi:10.1016/j.jag.2016.06.024

Hamzeh, S., Naseri, A.A., AlaviPanah, S.K., Mojaradi, B., Bartholomeus, H.M., Clevers, J.G.P.W., Behzad, M., 2013. Estimating salinity stress in sugarcane fields with spaceborne hyperspectral vegetation indices. Int. J. Appl. Earth Obs. Geoinf. 21, 282-290. doi:10.1016/j.jag.2012.07.002

Hansen, P.M., Schjoerring, J.K., 2003. Reflectance measurement of canopy biomass and nitrogen status in wheat crops using normalized difference vegetation indices and partial least squares regression. Remote Sens. Environ. 86, 542-553. 
doi:10.1016/S0034-4257(03)00131-7

Herzog, F., Steiner, B., Bailey, D., Baudry, J., Billeter, R., Bukácek, R., De Blust, G., De Cock, R., Dirksen, J., Dormann, C.F., De Filippi, R., Frossard, E., Liira, J., Schmidt, T., Stöckli, R., Thenail, C., Van Wingerden, W., Bugter, R., 2006. Assessing the intensity of temperate European agriculture at the landscape scale. Eur. J. Agron. 24, 165-181. doi:10.1016/j.eja.2005.07.006

Hoa, P.V., Giang, N.V., Binh, N.A., Hai, L.V.H., Pham, T.D., Hasanlou, M., Bui, D.T., 2019. Soil salinity mapping using SAR Sentinel-1 data and advanced machine learning algorithms: A case study at Ben Tre Province of the Mekong River Delta (Vietnam). Remote Sens. 11, 128. doi:10.3390/rs11020128

Homolová, L., Malenovský, Z., Clevers, J.G.P.W., García-Santos, G., Schaepman, M.E., 2013. Review of optical-based remote sensing for plant trait mapping. Ecol. Complex. 15, 1-16. doi:10.1016/j.ecocom.2013.06.003

Honnay, O., Piessens, K., Van Landuyt, W., Hermy, M., Gulinck, H., 2003. Satellite based land use and landscape complexity indices as predictors for regional plant species diversity. Landsc. Urban Plan. 63, 241-250. doi:10.1016/S01692046(02)00194-9

Hosseini, R., Newlands, N.K., Dean, C.B., Takemura, A., 2015. Statistical modeling of soil moisture, integrating satellite remotesensing (SAR) and ground-based data. Remote Sens. 7, 2752-2780. doi:10.3390/rs70302752

Houborg, R., Boegh, E., 2008. Mapping leaf chlorophyll and leaf area index using inverse and forward canopy reflectance modeling and SPOT reflectance data. Remote Sens. Environ. 112, 186-202. doi:10.1016/j.rse.2007.04.012

Houborg, R., Cescatti, A., Migliavacca, M., Kustas, W.P., 2013. Satellite retrievals of leaf chlorophyll and photosynthetic capacity for improved modeling of GPP. Agric. For. Meteorol. 177, 10-23. doi:10.1016/j.agrformet.2013.04.006

Hu, C., Chen, Z., Clayton, T.D., Swarzenski, P., Brock, J.C., Muller-Karger, F.E., 2004. Assessment of estuarine water-quality indicators using MODIS medium-resolution bands: Initial results from Tampa Bay, FL. Remote Sens. Environ. 93, $423-441$. doi:10.1016/j.rse.2004.08.007

Huang, C.-Y., Asner, G.P., 2009. Applications of Remote Sensing to Alien Invasive Plant Studies. Sensors 9, 4869-4889. doi:10.3390/s90604869

Huang, S., Ding, J., Zou, J., Liu, B., Zhang, J., Chen, W., 2019. Soil moisture retrival based on sentinel-1 imagery under sparse vegetation coverage. Sensors 19, 589. doi:10.3390/s19030589

Hunt, E.R., Doraiswamy, P.C., McMurtrey, J.E., Daughtry, C.S.T., Perry, E.M., Akhmedov, B., 2013. A visible band index for remote sensing leaf chlorophyll content at the canopy scale. Int. J. Appl. Earth Obs. Geoinf. 21, 103-112. doi:10.1016/j.jag.2012.07.020

Jackson, T.J., 2002. Remote sensing of soil moisture: Implications for groundwater recharge. Hydrogeol. J. 10, 40-51. doi:10.1007/s10040-001-0168-2

Jackson, T.J., Chen, D., Cosh, M., Li, F., Anderson, M., Walthall, C., Doriaswamy, P., Hunt, E.R., 2004. Vegetation water content mapping using Landsat data derived normalized difference water index for corn and soybeans. Remote Sens. Environ. 92, 475-482. doi:10.1016/j.rse.2003.10.021

Jain, M., Mondal, P., DeFries, R.S., Small, C., Galford, G.L., 2013. Mapping cropping intensity of smallholder farms: A comparison of methods using multiple sensors. Remote Sens. Environ. 134, 210-223. doi:10.1016/j.rse.2013.02.029

Jakubauskas, M.E., Legates, D.R., Kastens, J.H., 2002. Crop identification using harmonic analysis of time-series AVHRR NDVI data. Comput. Electron. Agric. 37, 127-139. doi:10.1016/S0168-1699(02)00116-3

Jennings, M.D., 2000. Gap analysis: Concepts, methods, and recent results. Landsc. Ecol. 15, 5-20. doi:10.1023/A:1008184408300

Jiang, D., Wang, N., Yang, X., Wang, J., 2003. Study on the interaction between NDVI profile and the growing status of crops. Chinese Geogr. Sci. 13, 62-65. doi:10.1007/s11769-003-0086-4

Johnson, D.M., 2013. A 2010 map estimate of annually tilled cropland within the conterminous United States. Agric. Syst. 114, 95-105. doi:10.1016/j.agsy.2012.08.004

Johnston, M., Licker, R., Foley, J., Holloway, T., Mueller, N.D., Barford, C., Kucharik, C., 2011. Closing the gap: global potential for 
increasing biofuel production through agricultural intensification. Environ. Res. Lett. 6, 1-11. doi:10.1088/1748$9326 / 6 / 3 / 034028$

Kalubarme, M.H., Potdar, M.B., Manjunath, K.R., Mahey, R.K., Siddhu, S.S., 2003. Growth profile based crop yield models: A case study of large area wheat yield modelling and its extendibility using atmospheric corrected NOAA AVHRR data. Int. J. Remote Sens. 24, 2037-2054. doi:10.1080/01431160210156018

Karnieli, A., Bayarjargal, Y., Bayasgalan, M., Mandakh, B., Dugarjav, C., Burgheimer, J., Khudulmur, S., Bazha, S.N., Gunin, P.D., 2013. Do vegetation indices provide a reliable indication of vegetation degradation? A case study in the Mongolian pastures. Int. J. Remote Sens. 34, 6243-6262. doi:10.1080/01431161.2013.793865

Kasampalis, D., Alexandridis, T., Deva, C., Challinor, A., Moshou, D., Zalidis, G., 2018. Contribution of Remote Sensing on Crop Models: A Review. J. Imaging 4, 52. doi:10.3390/jimaging4040052

Kasischke, E.S., Melack, J.M., Dobson, M.C., 1997. The use of imaging radars for ecological applications - A review. Remote Sens. Environ. 59, 141-156. doi:10.1016/S0034-4257(96)00148-4

Kerr, J.T., Cihlar, J., 2003. Land use and cover with intensity of agriculture for Canada from satellite and census data. Glob. Ecol. Biogeogr. 12, 161-172. doi:10.1046/j.1466-822X.2003.00017.x

Kerr, J.T., Ostrovsky, M., 2003. From space to species: Ecological applications for remote sensing. Trends Ecol. Evol. 18, $299-305$. doi:10.1016/S0169-5347(03)00071-5

Kerr, J.T., Southwood, T.R.E., Cihlar, J., 2001. Remotely sensed habitat diversity predicts butterfly species richness and community similarity in Canada. PNAS 98, 11365-11370. doi:10.1073/pnas.201398398

Khan, N.M., Rastoskuev, V. V., Sato, Y., Shiozawa, S., 2005. Assessment of hydrosaline land degradation by using a simple approach of remote sensing indicators. Agric. Water Manag. 77, 96-109. doi:10.1016/j.agwat.2004.09.038

Khanna, S., Palacios-Orueta, A., Whiting, M.L., Ustin, S.L., Riaño, D., Litago, J., 2007. Development of angle indexes for soil moisture estimation, dry matter detection and land-cover discrimination. Remote Sens. Environ. 109, $154-165$. doi:10.1016/j.rse.2006.12.018

Kimothi, M.M., Dasari, A., 2010. Methodology to map the spread of an invasive plant (Lantana camara L.) in forest ecosystems using Indian remote sensing satellite data. Int. J. Remote Sens. 31, 3273-3289. doi:10.1080/01431160903121126

Kloiber, S.M., Brezonik, P.L., Olmanson, L.G., Bauer, M.E., 2002. A procedure for regional lake water clarity assessment using Landsat multispectral data. Remote Sens. Environ. 82, 38-47. doi:10.1016/S0034-4257(02)00022-6

Koblinsky, C.J., Clarke, R.T., Brenner, A.C., Frey, H., 1993. Measurement of river level variations with satellite altimetry. Water Resour. Res. 29, 1839-1848. doi:10.1029/93WR00542

Kuenzer, C., Ottinger, M., Wegmann, M., Guo, H., Wang, C., Zhang, J., Dech, S., Wikelski, M., 2014. Earth observation satellite sensors for biodiversity monitoring: potentials and bottlenecks. Int. J. Remote Sens. 35, 6599-6647. doi:10.1080/01431161.2014.964349

Kumar, S., Gautam, G., Saha, S.K., 2015. Hyperspectral remote sensing data derived spectral indices in characterizing saltaffected soils: a case study of Indo-Gangetic plains of India. Environ. Earth Sci. 73, 3299-3308. doi:10.1007/s12665-0143613-y

Laba, M., Blair, B., Downs, R., Monger, B., Philpot, W., Smith, S., Sullivan, P., Baveye, P.C., 2010. Use of textural measurements to map invasive wetland plants in the Hudson River National Estuarine Research Reserve with IKONOS satellite imagery. Remote Sens. Environ. 114, 876-886. doi:10.1016/j.rse.2009.12.002

Laba, M., Downs, R., Smith, S., Welsh, S., Neider, C., White, S., Richmond, M., Philpot, W., Baveye, P., 2008. Mapping invasive wetland plants in the Hudson River National Estuarine Research Reserve using quickbird satellite imagery. Remote Sens. Environ. 112, 286-300. doi:10.1016/j.rse.2007.05.003

Lai, Y.R., Pringle, M.J., Kopittke, P.M., Menzies, N.W., Orton, T.G., Dang, Y.P., 2018. An empirical model for prediction of wheat yield, using time-integrated Landsat NDVI. Int. J. Appl. Earth Obs. Geoinf. 72, 99-108. doi:10.1016/j.jag.2018.07.013

Lauver, C.L., 1997. Mapping species diversity patterns in the Kansas shortgrass region by integrating remote sensing and vegetation analysis. J. Veg. Sci. 8, 387-394. doi:10.2307/3237328 
Lavery, P., Pattiaratchi, C., Wyllie, A., Hick, P., 1993. Water Quality Monitoring in Estuarine Waters Using the Landsat Thematic Mapper. Remote Sens. Environ. 46, 268-280. doi:10.1016/0034-4257(93)90047-2

Le Féon, V., Schermann-Legionnet, A., Delettre, Y., Aviron, S., Billeter, R., Bugter, R., Hendrickx, F., Burel, F., 2010. Intensification of agriculture, landscape composition and wild bee communities: A large scale study in four European countries. Agric. Ecosyst. Environ. 137, 143-150. doi:10.1016/j.agee.2010.01.015

Leblon, B., Guerif, M., Baret, F., 1991. The use of remotely sensed data in estimation of PAR use efficiency and biomass production of flooded rice. Remote Sens. Environ. 38, 147-158. doi:10.1016/0034-4257(91)90076-I

Li, L., Friedl, M.A., Xin, Q., Gray, J., Pan, Y., Frolking, S., 2014. Mapping crop cycles in China using MODIS-EVI time series. Remote Sens. 6, 2473-2493. doi:10.3390/rs6032473

Li, Z., Guo, X., 2012. Detecting climate effects on vegetation in northern mixed rairie using NOAA AVHRR 1-km time-series NDVI data. Remote Sens. 4, 120-134. doi:10.3390/rs4010120

Li, Z., Xu, D., Guo, X., 2014. Remote sensing of ecosystem health: opportunities, challenges, and future perspectives. Sensors 14, 21117-21139. doi:10.3390/s141121117

Liu, H., Li, Q., Shi, T., Hu, S., Wu, G., Zhou, Q., 2017. Application of Sentinel 2 MSI Images to Retrieve Suspended Particulate Matter Concentrations in Poyang Lake. Remote Sens. 9, 761. doi:10.3390/rs9070761

Liu, J., Pattey, E., Miller, J.R., McNairn, H., Smith, A., Hu, B., 2010. Estimating crop stresses, aboveground dry biomass and yield of corn using multi-temporal optical data combined with a radiation use efficiency model. Remote Sens. Environ. 114, 1167-1177. doi:10.1016/j.rse.2010.01.004

Lobell, D.B., Baldos, U.L.C., Hertel, T.W., 2013. Climate adaptation as mitigation: the case of agricultural investments. Environ. Res. Lett. 8, 1-12. doi:10.1088/1748-9326/8/1/015012

Luoto, M., Kuussaari, M., Toivonen, T., 2002a. Modelling butterfly distribution based on remote sensing data. J. Biogeogr. 29, 1027-1037. doi:10.1046/j.1365-2699.2002.00728.x

Luoto, M., Toivonen, T., Heikkinen, R.K., 2002b. Prediction of total and rare plant species richness in agricultural landscapes from satellite images and topographic data. Landsc. Ecol. 17, 195-217. doi:10.1023/A:1020288509837

Mairota, P., Cafarelli, B., Didham, R.K., Lovergine, F.P., Lucas, R.M., Nagendra, H., Rocchini, D., Tarantino, C., 2015. Challenges and opportunities in harnessing satellite remote-sensing for biodiversity monitoring. Ecol. Inform. 30, $207-214$. doi:10.1016/j.ecoinf.2015.08.006

Martinez, J.M., Guyot, J.L., Cochonneau, G., 2008. Monitoring of surface water quality in large rivers with satellite imagery Application to the Amazon basin. www.iwra.org/congress/resource/abs649_article.pdf.

Mashimbye, Z.E., Cho, M.A., Nell, J.P., De clercq, W.P., Van niekerk, A., Turner, D.P., 2012. Model-Based Integrated Methods for Quantitative Estimation of Soil Salinity from Hyperspectral Remote Sensing Data: A Case Study of Selected South African Soils. Pedosphere 22, 640-649. doi:10.1016/S1002-0160(12)60049-6

McGarigal, K., Cushman, S.A., Ene, E., 2012. FRAGSTATS v4: Spatial Pattern Analysis Program for Categorical Maps [WWW Document]. URL http://www.umass.edu/landeco/research/fragstats/fragstats.html (accessed 4.21.17).

Metternicht, G.I., Zinck, J.A., 2003. Remote sensing of soil salinity: potentials and constraints. Remote Sens. Environ. 85, 1-20. doi:10.1016/S0034-4257(02)00188-8

Metternicht, G.I., Zinck, J.A., 1998. Evaluating the information content of JERS-1 SAR and Landsat TM data for discrimination of soil erosion features. ISPRS J. Photogramm. Remote Sens. 53, 143-153. doi:10.1016/S0924-2716(98)00004-5

Meynard, C.N., Quinn, J.F., 2007. Predicting species distributions: a critical comparison of the most common statistical models using artificial species. J. Biogeogr. 34, 1455-1469. doi:10.1111/j.1365-2699.2007.01720.x

Michailovsky, C.I., McEnnis, S., Berry, P.A.M., Smith, R., Bauer-Gottwein, P., 2012. River monitoring from satellite radar altimetry in the Zambezi River basin. Hydrol. Earth Syst. Sci. 16, 2181-2192. doi:10.5194/hess-16-2181-2012

Mingwei, Z., Qingbo, Z., Zhongxin, C., Jia, L., Yong, Z., Chongfa, C., 2008. Crop discrimination in Northern China with double cropping systems using Fourier analysis of time-series MODIS data. Int. J. Appl. Earth Obs. Geoinf. 10, 476-485. doi:10.1016/j.jag.2007.11.002 
Mirik, M., Ansley, R.J., 2012. Utility of Satellite and Aerial Images for Quantification of Canopy Cover and Infilling Rates of the Invasive Woody Species Honey Mesquite (Prosopis Glandulosa) on Rangeland. Remote Sens. 4, 1947-1962. doi:10.3390/rs4071947

Monteith, J.L., 1972. Solar Radiation and Productivity in Tropical Ecosystems. J. Appl. Ecol. 9, 747-766. doi:10.2307/2401901

Morel, J., Todoroff, P., Bégué, A., Bury, A., Martiné, J.F., Petit, M., 2014. Toward a satellite-based system of sugarcane yield estimation and forecasting in smallholder farming conditions: A case study on reunion island. Remote Sens. 6, 6620-6635. doi:10.3390/rs6076620

Moriondo, M., Maselli, F., Bindi, M., 2007. A simple model of regional wheat yield based on NDVI data. Eur. J. Agron. 26, 266274. doi:10.1016/j.eja.2006.10.007

Mueller, N., Lewis, A., Roberts, D., Ring, S., Melrose, R., Sixsmith, J., Lymburner, L., Mclntyre, A., Tan, P., Curnow, S., Ip, A., 2016. Water observations from space: Mapping surface water from 25years of Landsat imagery across Australia. Remote Sens. Environ. 174, 341-352. doi:10.1016/j.rse.2015.11.003

Muñoz, J., Felicísimo, Á.M., 2004. Comparison of statistical methods commonly used in predictive modelling. J. Veg. Sci. 15, 285292. doi:10.1111/j.1654-1103.2004.tb02263.x

Mutiga, J.K., Su, Z., Woldai, T., 2010. Using satellite remote sensing to assess evapotranspiration: Case study of the upper Ewaso Ng'iro North Basin, Kenya. Int. J. Appl. Earth Obs. Geoinf. 12S, S100-S108. doi:10.1016/j.jag.2009.09.012

Myneni, R.B., Nemani, R.R., Running, S.W., 1997. Estimation of global leaf area index and absorbed PAR using radiative transfer models. IEEE Trans. Geosci. Remote Sens. 35, 1380-1393. doi:10.1109/36.649788

Nagendra, H., 2001. Using remote sensing to assess biodiversity. Int. J. Remote Sens. 22, 2377-2400. doi:10.1080/01431160117096

Nagendra, H., Gadgil, M., 1999. Satellite Imagery as a Tool for Monitoring Species Diversity: An Assessment. J. Appl. Ecol. 36, 388-397. doi:10.1046/j.1365-2664.1999.00406.x

Nagy, A., Fehér, J., Tamás, J., 2018. Wheat and maize yield forecasting for the Tisza river catchment using MODIS NDVI time series and reported crop statistics. Comput. Electron. Agric. 151, 41-49. doi:10.1016/j.compag.2018.05.035

Ngoc, D.D., Loisel, H., Jamet, C., Vantrepotte, V., Duforêt-Gaurier, L., Minh, C.D., Mangin, A., 2019. Coastal and inland water pixels extraction algorithm (WiPE) from spectral shape analysis and HSV transformation applied to Landsat 8 OLI and Sentinel-2 MSI. Remote Sens. Environ. 223, 208-228. doi:10.1016/j.rse.2019.01.024

Niedertscheider, M., Kastner, T., Fetzel, T., Haberl, H., Kroisleitner, C., Plutzar, C., Erb, K.-H., 2016. Mapping and analysing cropland use intensity from a NPP perspective. Environ. Res. Lett. 11. doi:10.1088/1748-9326/11/1/014008

Numata, I., Roberts, D.A., Chadwick, O.A., Schimel, J., Sampaio, F.R., Leonidas, F.C., Soares, J. V., 2007. Characterization of pasture biophysical properties and the impact of grazing intensity using remotely sensed data. Remote Sens. Environ. 109, 314-327. doi:10.1016/j.rse.2007.01.013

Olofsson, P., Lagergren, F., Lindroth, A., Lindström, J., Klemedtsson, L., Kutsch, W., Eklundh, L., 2008. Towards operational remote sensing of forest carbon balance across Northern Europe. Biogeosciences 5, 817-832. doi:10.5194/bg-5-817-2008

Pacheco, A., McNairn, H., 2010. Evaluating multispectral remote sensing and spectral unmixing analysis for crop residue mapping. Remote Sens. Environ. 114, 2219-2228. doi:10.1016/j.rse.2010.04.024

Palacios-Orueta, A., Ustin, S.L., 1998. Remote sensing of soil properties in the Santa Monica Mountains I. Spectral analysis. Remote Sens. Environ. 65, 170-183. doi:10.1016/S0034-4257(98)00024-8

Palmer, M.W., Earls, P.G., Hoagland, B.W., White, P.S., Wohlgemuth, T., 2002. Quantitative tools for perfecting species lists. Environmetrics 13, 121-137. doi:10.1002/env.516

Pan, G., Sun, G.J., Li, F.M., 2009. Using QuickBird imagery and a production efficiency model to improve crop yield estimation in the semi-arid hilly Loess Plateau, China. Environ. Model. Softw. 24, 510-516. doi:10.1016/j.envsoft.2008.09.014

Patel, N.R., Bhattacharjee, B., Mohammed, A.J., Tanupriya, B., Saha, S.K., 2006. Remote sensing of regional yield assessment of wheat in Haryana, India. Int. J. Remote Sens. 27, 4071-4090. doi:10.1080/01431160500377188 
Pereira-Sandoval, M., Ruiz-Verdu, A., Tenjo, C., Delegido, J., Urrego, P., Pena, R., Vicente, E., Soria, J., Soria, J., Moreno, J., 2018. Calibration and Validation of Algorithms for the Estimation of Chlorophyll-A Concentration and Secchi Depth in Inland Waters with Sentinel-2. Limnetica 38, 471-487. doi:10.1109/igarss.2018.8517371

Petropoulos, G.P., Srivastava, P.K., Piles, M., Pearson, S., 2018. Earth observation-based operational estimation of soil moisture and evapotranspiration for agricultural crops in support of sustainable water management. Sustainability $10,181$. doi:10.3390/su10010181

Ponnurangam, G.G., Rao, Y.S., 2018. The application of compact polarimetric decomposition algorithms to L-band PolSAR data in agricultural areas. Int. J. Remote Sens. 39, 8337-8360. doi:10.1080/01431161.2018.1488281

Potter, P., Ramankutty, N., Bennett, E.M., Donner, S.D., 2010. Characterizing the spatial patterns of global fertilizer application and manure production. Earth Interact. 14, 1-22. doi:10.1175/2009EI288.1

Prasad, A.K., Chai, L., Singh, R.P., Kafatos, M., 2006. Crop yield estimation model for lowa using remote sensing and surface parameters. Int. J. Appl. Earth Obs. Geoinf. 8, 26-33. doi:10.1016/j.jag.2005.06.002

Qian, T., Tsunekawa, A., Peng, F., Masunaga, T., Wang, T., Li, R., 2019. Derivation of salt content in salinized soil from hyperspectral reflectance data: A case study at Minqin Oasis, Northwest China. J. Arid Land 11, 111-122. doi:10.1007/s40333-019-0091-9

Rahman, M.M., Moran, M.S., Thoma, D.P., Bryant, R., Holifield Collins, C.D., Jackson, T., Orr, B.J., Tischler, M., 2008. Mapping surface roughness and soil moisture using multi-angle radar imagery without ancillary data. Remote Sens. Environ. 112, 391-402. doi:10.1016/j.rse.2006.10.026

Ravan, S.A., Roy, P.S., Sharma, C.M., 1995. Space remote sensing for spatial vegetation characterization. J. Biosci 20, 427-438.

Reidsma, P., Tekelenburg, T., Van Den Berg, M., Alkemade, R., 2006. Impacts of land-use change on biodiversity: An assessment of agricultural biodiversity in the European Union. Agric. Ecosyst. Environ. 114, 86-102. doi:10.1016/j.agee.2005.11.026

Ren, J., Chen, Z., Zhou, Q., Tang, H., 2008. Regional yield estimation for winter wheat with MODIS-NDVI data in Shandong, China. Int. J. Appl. Earth Obs. Geoinf. 10, 403-413. doi:10.1016/j.jag.2007.11.003

Ritchie, J.C., Cooper, C.M., 2001. Remote sensing techniques for determining water quality: Applications to TMDLs, in: TMDL Science Issues Conference (2001), Water Environment Federation, Alexandria, VA. pp. 367-374.

Rocchini, D., Balkenhol, N., Carter, G.A., Foody, G.M., Gillespie, T.W., He, K.S., Kark, S., Levin, N., Lucas, K., Luoto, M., Nagendra, H., Oldeland, J., Ricotta, C., Southworth, J., Neteler, M., 2010. Remotely sensed spectral heterogeneity as a proxy of species diversity: Recent advances and open challenges. Ecol. Inform. 5, 318-329. doi:10.1016/j.ecoinf.2010.06.001

Rocchini, D., Ricotta, C., Chiarucci, A., 2007. Using satellite imagery to assess plant species richness: The role of multispectral systems. Appl. Veg. Sci. 10, 325-331. doi:10.1111/j.1654-109X.2007.tb00431.x

Ruimy, A., Saugier, B., 1994. Methodology for the estimation of terrestrial net primary production from remotely sensed data. J. Geophys. Res. 99, 5263-5283. doi:10.1029/93JD03221

Sakowska, K., Juszczak, R., Gianelle, D., 2016. Remote Sensing of Grassland Biophysical Parameters in the Context of the Sentinel-2 Satellite Mission. J. Sensors 2016, 1-16. doi:10.1155/2016/4612809

Salazar, L., Kogan, F., Roytman, L., 2007. Use of remote sensing data for estimation of winter wheat yield in the United States. Int. J. Remote Sens. 28, 3795-3811. doi:10.1080/01431160601050395

Saura, S., 2004. Effects of remote sensor spatial resolution and data aggregation on selected fragmentation indices. Landsc. Ecol. 19, 197-209. doi:10.1023/B:LAND.0000021724.60785.65

Saveraid, E.H., Debinski, D.M., Kindscher, K., Jakubauskas, M.E., 2001. A comparison of satellite data and landscape variables in predicting bird species occurrences in the Greater Yellowstone Ecosystem, USA. Landsc. Ecol. 16, 71-83. doi:10.1023/A:1008119219788

Scharf, P., Schmidt, J.P., Kitchen, N.R., Sudduth, K.A., 2002. Remote sensing for nitrogen management. J. Soil Water Conserv. 57, 518-524.

Schino, G., Borfecchia, F., De Cecco, L., Dibari, C., lannetta, M., Martini, S., Pedrotti, F., 2003. Satellite estimate of grass biomass in a mountainous range in central Italy. Agrofor. Syst. 59, 157-162. doi:10.1023/A:1026308928874 
Schumaker, N.H., 1996. Using landscape indices to predict habitat connectivity. Ecology 77, 1210-1225. doi:10.2307/2265590

Sharma, K.D., Singh, S., 1995. Satellite remote sensing for soil erosion modelling using the ANSWERS model. Hydrol. Sci. 40, 259272. doi:10.1080/02626669509491408

Shoshany, M., Goldshleger, N., Chudnovsky, A., 2013. Monitoring of agricultural soil degradation by remote-sensing methods: a review. Int. J. Remote Sens. 34, 6152-6181. doi:10.1080/01431161.2013.793872

Shuai, G., Zhang, J., Basso, B., Pan, Y., Zhu, X., Zhu, S., Liu, H., 2019. Multi-temporal RADARSAT-2 polarimetric SAR for maize mapping supported by segmentations from high-resolution optical image. Int. J. Appl. Earth Obs. Geoinf. 74, 1-15. doi:10.1016/j.jag.2018.08.021

Sibanda, M., Mutanga, O., Rouget, M., 2015. Examining the potential of Sentinel-2 MSI spectral resolution in quantifying above ground biomass across different fertilizer treatments. ISPRS J. Photogramm. Remote Sens. 110, 55-65. doi:10.1016/j.isprsjprs.2015.10.005

Siebert, S., Portmann, F.T., Döll, P., 2010. Global patterns of cropland use intensity. Remote Sens. 2, 1625-1643. doi:10.3390/rs2071625

Singh, R., Semwal, D.P., Rai, A., Chhikara, R.S., 2002. Small area estimation of crop yield using remote sensing satellite data. Int. J. Remote Sens. 23, 49-56. doi:10.1080/01431160010014756

Smith, L.C., 1997. Satellite remote sensing of river inundation area, stage, and discharge: a review. Hydrol. Process. 11, 14271439. doi:10.1002/(SICI)1099-1085(199708)11:10<1427::AID-HYP473>3.0.CO;2-S

Son, N.T., Chen, C.F., Chen, C.R., Minh, V.Q., Trung, N.H., 2014. A comparative analysis of multitemporal MODIS EVI and NDVI data for large-scale rice yield estimation. Agric. For. Meteorol. 197, 52-64. doi:10.1016/j.agrformet.2014.06.007

Sòria-perpinyà, X., Urrego, P., Pereira-sandoval, M., Ruiz-verdú, A., Peña, R., Soria, J.M., Delegido, J., Vicente, E., Moreno, J., València, U. De, José, C.C., Martínez, B., Martínez, B., 2019. Monitoring the ecological state of a hypertrophic lake ( Albufera of València, Spain ) using multitemporal Sentinel-2 images 38, 457-469. doi:10.23818/limn.38.26

Srivastava, P.K., 2017. Satellite Soil Moisture: Review of Theory and Applications in Water Resources. Water Resour. Manag. 31, 3161-3176. doi:10.1007/s11269-017-1722-6

Stevens, A., Udelhoven, T., Denis, A., Tychon, B., Lioy, R., Hoffmann, L., van Wesemael, B., 2010. Measuring soil organic carbon in croplands at regional scale using airborne imaging spectroscopy. Geoderma 158, 32-45. doi:10.1016/j.geoderma.2009.11.032

Stickler, C.M., Southworth, J., 2008. Application of multi-scale spatial and spectral analysis for predicting primate occurrence and habitat associations in Kibale National Park, Uganda. Remote Sens. Environ. 112, 2170-2186.

doi:10.1016/j.rse.2007.10.013

Sulistioadi, Y.B., Tseng, K.H., Shum, C.K., Hidayat, H., Sumaryono, M., Suhardiman, A., Setiawan, F., Sunarso, S., 2015. Satellite radar altimetry for monitoring small rivers and lakes in Indonesia. Hydrol. Earth Syst. Sci. 19, 341-359. doi:10.5194/hess19-341-2015

Taghadosi, M.M., Hasanlou, M., Eftekhari, K., 2019. Soil salinity mapping using dual-polarized SAR Sentinel-1 imagery. Int. J. Remote Sens. 40, 237-252. doi:10.1080/01431161.2018.1512767

Taylor, G.R., Mah, A.H., Kruse, F.A., Kierein-Young, K.S., Hewson, R.D., Bennett, B.A., 1996. Characterization of Saline Soils Using Airborne Radar Imagery. Remote Sens. Environ. 57, 127-142. doi:10.1016/0034-4257(95)00239-1

Teillard, F., Allaire, G., Cahuzac, E., Léger, F., Maigné, E., Tichit, M., 2012. A novel method for mapping agricultural intensity reveals its spatial aggregation: Implications for conservation policies. Agric. Ecosyst. Environ. 149, 135-143. doi:10.1016/j.agee.2011.12.018

Temme, A.J.A.M., Verburg, P.H., 2011. Mapping and modelling of changes in agricultural intensity in Europe. Agric. Ecosyst. Environ. 140, 46-56. doi:10.1016/j.agee.2010.11.010

Thenkabail, P.S., Biradar, C.M., Noojipady, P., Dheeravath, V., Li, Y., Velpuri, M., Gumma, M., Gangalakunta, O.R.P., Turral, H., Cai, X., Vithanage, J., Schull, M. a., Dutta, R., 2009. Global irrigated area map (GIAM), derived from remote sensing, for the end of the last millennium. Int. J. Remote Sens. 30, 3679-3733. doi:10.1080/01431160802698919 
Tilling, A.K., O'Leary, G.J., Ferwerda, J.G., Jones, S.D., Fitzgerald, G.J., Rodriguez, D., Belford, R., 2007. Remote sensing of nitrogen and water stress in wheat. F. Crop. Res. 104, 77-85. doi:10.1016/j.fcr.2007.03.023

Trivero, P., Borasi, M., Biamino, W., Cavagnero, M., Rinaudo, C., Bonansea, M., Lanfri, S., 2013. River pollution remediation monitored by optical and infrared high-resolution satellite images. Environ. Monit. Assess. 185, 7647-7658. doi:10.1007/s10661-013-3125-3

Trombetti, M., Riaño, D., Rubio, M.A., Cheng, Y.B., Ustin, S.L., 2008. Multi-temporal vegetation canopy water content retrieval and interpretation using artificial neural networks for the continental USA. Remote Sens. Environ. 112, $203-215$. doi:10.1016/j.rse.2007.04.013

Tsai, F., Chou, M.J., 2006. Texture augmented analysis of high resolution satellite imagery in detecting invasive plant species. J. Chinese Inst. Eng. 29, 581-592. doi:10.1080/02533839.2006.9671155

Tsai, F., Lin, E.K., Yoshino, K., 2007. Spectrally segmented principal component analysis of hyperspectral imagery for mapping invasive plant species. Int. J. Remote Sens. 28, 1023-1039. doi:10.1080/01431160600887706

Tulbure, M.G., Broich, M., 2013. Spatiotemporal dynamic of surface water bodies using Landsat time-series data from 1999 to 2011. ISPRS J. Photogramm. Remote Sens. 79, 44-52. doi:10.1016/j.isprsjprs.2013.01.010

Turner, D.P., Cohen, W.B., Kennedy, R.E., Fassnacht, K.S., Briggs, J.M., 1999. Relationships between Leaf Area Index and Landsat TM Spectral Vegetation Indices across Three Temperate Zone Sites. Remote Sens. Environ. 70, 52-68. doi:10.1016/S00344257(99)00057-7

Turner, W., Spector, S., Gardiner, N., Fladeland, M., Sterling, E., Steininger, M., 2003. Remote sensing for biodiversity science and conservation. Trends Ecol. Evol. 18, 306-314. doi:10.1016/S0169-5347(03)00070-3

van Leeuwen, M., Nieuwenhuis, M., 2010. Retrieval of forest structural parameters using LiDAR remote sensing. Eur. J. For. Res. 129, 749-770. doi:10.1007/s10342-010-0381-4

Vannier, C., Vasseur, C., Hubert-Moy, L., Baudry, J., 2011. Multiscale ecological assessment of remote sensing images. Landsc. Ecol. 26, 1053-1069. doi:10.1007/s10980-011-9626-y

Verhoef, W., 1984. Light scattering by leaf layers with application to canopy reflectance modeling: The SAIL model. Remote Sens. Environ. 16, 125-141. doi:10.1016/0034-4257(84)90057-9

Verpoorter, C., Kutser, T., Tranvik, L., 2012. Automated mapping of water bodies using Landsat multispectral data. Limnol. Oceanogr. Methods 10, 1037-1050. doi:10.4319/lom.2012.10.1037

Verstraeten, W.W., Veroustraete, F., Van Der Sande, C.J., Grootaers, I., Feyen, J., 2006. Soil moisture retrieval using thermal inertia, determined with visible and thermal spaceborne data, validated for European forests. Remote Sens. Environ. 101, 299-314. doi:10.1016/j.rse.2005.12.016

Vibhute, A.D., Gawali, B.W., 2013. Analysis and Modeling of Agricultural Land use using Remote Sensing and Geographic Information System: a Review. Int. J. Eng. Res. Appl. 3, 81-91.

Vignolo, A., Pochettino, A., Cicerone, D., 2006. Water quality assessment using remote sensing techniques: Medrano Creek, Argentina. J. Environ. Manage. 81, 429-433. doi:10.1016/j.jenvman.2005.11.019

Vrieling, A., 2006. Satellite remote sensing for water erosion assessment: A review. Catena 65, 2-18. doi:10.1016/j.catena.2005.10.005

Wagner, W., Naeimi, V., Scipal, K., Jeu, R., Martínez-Fernández, J., 2007. Soil moisture from operational meteorological satellites. Hydrogeol. J. 15, 121-131. doi:10.1007/s10040-006-0104-6

Walsh, S.J., McCleary, A.L., Mena, C.F., Shao, Y., Tuttle, J.P., González, A., Atkinson, R., 2008. QuickBird and Hyperion data analysis of an invasive plant species in the Galapagos Islands of Ecuador: Implications for control and land use management. Remote Sens. Environ. 112, 1927-1941. doi:10.1016/j.rse.2007.06.028

Wang, B., Jia, K., Liang, S., Xie, X., Wei, X., Zhao, X., Yao, Y., Zhang, X., 2018. Assessment of Sentinel-2 MSI Spectral Band Reflectances for Estimating Fractional Vegetation Cover. Remote Sens. 10, 1927. doi:10.3390/rs10121927

Wang, K., Franklin, S.E., Guo, X., Cattet, M., 2010. Remote sensing of ecology, biodiversity and conservation: A review from the perspective of remote sensing specialists. Sensors 10, 9647-9667. doi:10.3390/s101109647 
Wang, L., Huang, J., Du, Y., Hu, Y., Han, P., 2013. Dynamic assessment of soil erosion risk using landsat TM and HJ satellite data in danjiangkou reservoir area, China. Remote Sens. 5, 3826-3848. doi:10.3390/rs5083826

Wang, L., Qu, J.J., 2009. Satellite remote sensing applications for surface soil moisture monitoring: A review. Front. Earth Sci. China 3, 237-247. doi:10.1007/s11707-009-0023-7

Wardlow, B.D., Egbert, S.L., 2008. Large-area crop mapping using time-series MODIS 250 m NDVI data: An assessment for the U.S. Central Great Plains. Remote Sens. Environ. 112, 1096-1116. doi:10.1016/j.rse.2007.07.019

Wardlow, B.D., Egbert, S.L., Kastens, J.H., 2007. Analysis of time-series MODIS 250m vegetation index data for crop classification in the U.S. Central Great Plains. Remote Sens. Environ. 108, 290-310. doi:10.1016/j.rse.2006.11.021

Weiers, S., Bock, M., Wissen, M., Rossner, G., 2004. Mapping and indicator approaches for the assessment of habitats at different scales using remote sensing and GIS methods. Landsc. Urban Plan. 67, 43-65. doi:10.1016/S0169-2046(03)000288

Wen, X., Yang, X., 2010. Monitoring of water quality using remote sensing techniques. Appl. Mech. Mater. 29-32, 2360-2364. doi:10.4028/www.scientific.net/AMM.29-32.2360

Weng, Y., Gong, P., Zhu, Z., 2008. Soil salt content estimation in the Yellow River delta with satellite hyperspectral data. Can. J. Remote Sens. 34, 259-270. doi:10.5589/m08-017

Wolter, P.T., Johnston, C.A., Niemi, G.J., 2005. Mapping submergent aquatic vegetation in the US Great Lakes using Quickbird satellite data. Int. J. Remote Sens. 26, 5255-5274. doi:10.1080/01431160500219208

Wu, B., Gommes, R., Zhang, M., Zeng, H., Yan, N., Zou, W., Zheng, Y., Zhang, N., Chang, S., Xing, Q., van Heijden, A., 2015. Global crop monitoring: A satellite-based hierarchical approach. Remote Sens. 7, 3907-3933. doi:10.3390/rs70403907

Wu, B., Meng, J., Li, Q., Yan, N., Du, X., Zhang, M., 2014. Remote sensing-based global crop monitoring: Experiences with China's CropWatch system. Int. J. Digit. Earth 7, 113-137. doi:10.1080/17538947.2013.821185

Wu, C., Wu, J., Qi, J., Zhang, L., Huang, H., Lou, L., Chen, Y., 2010. Empirical estimation of total phosphorus concentration in the mainstream of the Qiantang River in China using Landsat TM data. Int. J. Remote Sens. 31, 2309-2324. doi:10.1080/01431160902973873

Wulder, M.A., Hall, R.J., Coops, Nicholas, C., Franklin, S.E., 2004. High spatial resolution remotely sensed data for ecosystem characterisation. Bioscience 54, 511-521.

Xiao, X., Jian, X., Xiongfei, W., Chengfang, H., Xuejun, C., Zhaohui, W., Dengzhong, Z., 2015. Evaluation method of water quality for river based on multi-spectral remote sensing data, in: International Archives of the Photogrammetry, Remote Sensing and Spatial Information Sciences - ISPRS Archives. doi:10.5194/isprsarchives-XL-7-W3-1517-2015

Xie, H., Zou, J., Jiang, H., Zhang, N., Choi, Y., 2014. Spatiotemporal pattern and driving forces of arable land-use intensity in China: Toward sustainable land management using emergy analysis. Sustainability 6, 3504-3520. doi:10.3390/su6063504

Xu, C., Li, Y., Hu, J., Yang, X., Sheng, S., Liu, M., 2012. Evaluating the difference between the normalized difference vegetation index and net primary productivity as the indicators of vegetation vigor assessment at landscape scale. Environ. Monit. Assess. 184, 1275-1286. doi:10.1007/s10661-011-2039-1

Xu, L., Zhang, H., Wang, C., Zhang, B., Liu, M., 2019. Crop classification based on temporal information using Sentinel-1 SAR timeseries data. Remote Sens. 11, 53. doi:10.3390/rs11010053

Yan, H., Xiao, X., Huang, H., Liu, J., Chen, J., Bai, X., 2014. Multiple Cropping Intensity in China Derived from Agro-meteorological Observations and MODIS Data. Chinese Geogr. Sci. 24, 205-219. doi:10.1007/s11769-013-0637-2

Yang, C., Everitt, J.H., Bradford, J.M., 2006. Comparison of QuickBird satellite imagery and airborne imagery for mapping grain sorghum yield patterns. Precis. Agric. 7, 33-44. doi:10.1007/s11119-005-6788-0

Yang, X., 2005. Remote sensing and GIS applications for estuarine ecosystem analysis: An overview. Int. J. Remote Sens. 26, 5347-5356. doi:10.1080/01431160500219406

Zhang, M., Wu, B., Yu, M., Zou, W., Zheng, Y., 2014. Crop condition assessment with adjusted NDVI using the uncropped arable land ratio. Remote Sens. 6, 5774-5794. doi:10.3390/rs6065774 
Zhang, W., Li, H., 2016. Characterizing and Assessing the Agricultural Land Use Intensity of the Beijing Mountainous Region. Sustainability 8, 1-18. doi:10.3390/su8111180

Zhang, Y., Atkinson, P.M., Li, X., Ling, F., Wang, Q., Du, Y., 2017. Learning-Based Spatial-Temporal Superresolution Mapping of Forest Cover with MODIS Images. IEEE Trans. Geosci. Remote Sens. 55, 600-614. doi:10.1109/TGRS.2016.2613140 